\title{
The Status of Hydrogen Technologies in the UK: A Multi-Disciplinary Review
}

\author{
(Corresponding Author) Reace Louise Edwards ${ }^{\mathrm{a}}$ Department of Chemical Engineering, Thornton Science Park, \\ University of Chester, Chester, $\mathrm{CH} 2$ 4NU, UK \\ 1502230@chester.ac.uk \\ Carolina Font-Palma ${ }^{a}$ Department of Chemical Engineering, Thornton Science Park, University of Chester, \\ Chester, $\mathrm{CH} 2$ 4NU, UK \\ c.fontpalma@chester.ac.uk \\ Joe Howe ${ }^{\mathrm{a}}$ Department of Chemical Engineering, Thornton Science Park, University of Chester, Chester, $\mathrm{CH} 2$ \\ 4NU, UK \\ j.howe@chester.ac.uk
}

\begin{abstract}
Hydrogen has the potential to offer deep decarbonisation across a range of global heavy-emitting sectors. To have an impact on the global energy system, hydrogen technologies must be deployed with greater urgency. This review article facilitates the much needed, multi-disciplinary discussion around hydrogen. In doing so, the paper outlines recent advancements, prevailing challenges and areas of future research concerning hydrogen technologies, policy, regulation and social considerations in a UK setting. Findings suggest that hydrogen will play a significant role in decarbonising several UK sectors whilst simultaneously addressing challenges faced by alternative low-carbon technologies. Optimal production, delivery and storage systems must be developed to accommodate perceived future demand. Whilst this will be largely dictated by scale, efficiency, cost and technological maturity, significant improvements in existing policies and regulation will also be critical. The future role of hydrogen in the UK's decarbonisation strategy is not clearly defined. In comparison to alternative low-carbon technologies, policy and regulatory support for hydrogen has been minimal. Whilst there is growing evidence concerning the public perception of hydrogen in UK homes, additional research is required given its many potential applications. The findings detailed in this article support the urgency for further multi-disciplinary collaborative research.
\end{abstract}

Key Words: Hydrogen, Decarbonisation, Review, Multi-Disciplinary, Industrial Clusters

\section{Abbreviations $^{1}$}

\footnotetext{
${ }^{1}$ ULEV: Ultra-low emission vehicle, HFC: Hydrogen fuel cell, BEV: Battery electric vehicle, HHV: Higher heating value, LHV: Lower heating value, WI: Wobbe Index, TRL: Technology readiness level, CCS: Carbon capture and storage, SMR: Steam methane reforming, PSA: Pressure swing adsorption, ATR: Auto-thermal reforming, POX: Partial oxidation, LCH: Low-carbon hydrogen, GHR: Gas heated reactor, PEM: Polymer exchange membranes, SOEC: Solid oxide electrolysis cells, LOHC: Liquid organic hydrogen carrier, PtX: Power to X, MOF: Metal organic framework, EU-ETS: EU Emission Trading System, R\&D: Research and Development, NIC: Network innovation competition, HRS: Hydrogen refuelling station, LSIP: Large scale integrated projects, MoU: Memorandum of Understanding, FEED: Front-End engineering design, FID: Final investment decision, BEIS: Department for Business, Energy and Industrial Strategy
} 


\section{Introduction}

In 2018, global $\mathrm{CO}_{2}$ emissions peaked at $408.52 \mathrm{ppm}$, which was the highest level observed in over 800,000 years [1]. Furthermore, global energy-related $\mathrm{CO}_{2}$ emissions rose by $1.7 \%$ to a historic high of 33.1Gt as a result of greater energy demands [2]. Atmospheric warming attributable to anthropogenic emissions will persist for centuries to millennia and will continue to have long-term effects on the climate system [3]. To strengthen the global response to this issue, the Climate Change Act seeks to maintain a global temperature rise of well below $2^{\circ} \mathrm{C}$ with efforts to limit this even further to $1.5^{\circ} \mathrm{C}$ [4]. To align with the $1.5^{\circ} \mathrm{C}$ target, global emissions must decrease by $7.6 \%$ per annum between 2020-2030 [5]. This will require significant transitions in energy, land, infrastructure and industrial systems within a rapid timeframe [3]. Low-carbon hydrogen could play a major role in these decarbonisation efforts.

Hydrogen is a versatile fuel with net-zero end use emissions [6], which can be utilised to decarbonise numerous heavy emitting sectors like transport, industry and electricity and heat generation, which account for approximately $90 \%$ of global $\mathrm{CO}_{2}$ emissions [7]. Other specific roles hydrogen could play in decarbonisation include:

- Enabling large-scale renewable energy integration and power generation

- Distributing energy across sectors and regions

- Acting as a buffer to increase energy system resilience [8].

The concept of using hydrogen as a substitute for conventional fossil-fuels can be tracked back decades. In 1977, Bockris envisioned a "system of industry, transportation, and household energy which depends on piped hydrogen as a fuel" and coined this the 'hydrogen economy' [9].

The global demand for hydrogen (74 million tonnes) is now more than triple that observed in 1975 [10]. At present, most hydrogen produced is fossil fuel dependent and carbon intensive. However, by 2050 , low-carbon hydrogen could meet $18 \%$ of total energy demand, create 30 million new jobs and reduce $6 \mathrm{Gt}$ of $\mathrm{CO}_{2}$ emissions per annum [8]. This equates to an annual demand approximately ten times larger than that observed at present. Therefore, low-carbon hydrogen production needs to proceed with greater urgency [11].

In the UK, there are many projects and initiatives seeking to demonstrate its potential, and subsequently create a market, for hydrogen production, storage, transmission and distribution and end-use technologies. Despite this, the role of hydrogen in the UK's decarbonisation strategy remains undefined. Challenges faced for hydrogen span beyond those of a technical nature. Policy and regulatory barriers currently prohibit the advancement of hydrogen technologies. The potential social implications must also be understood and addressed.

A collaborative approach across numerous stakeholders and disciplines is pivotal to establishing a market for hydrogen. Despite the ever-increasing body of literature concerning hydrogen, there are few publications that address its wider context by incorporating research from multiple disciplines. Typically, research articles tend to focus on hydrogen technologies from one subject field, whether it be of a technical, social or policy nature. Whilst some articles do touch upon other disciplines, this is not pulled together in a multi-disciplinary manner. To address this existing literature gap, this article aims to review the status of hydrogen technologies in the UK and facilitate the much-needed wider discussion around hydrogen by adopting a multi-disciplinary approach. This article outlines recent advancements, prevailing challenges, and areas of future research in terms of hydrogen technologies, policy, regulation, and social considerations. To provide an overview of the progression of hydrogen technologies to date, a brief outline of the status of on-going hydrogen 
initiatives is also provided. To summarise, the importance of establishing global hydrogen markets is discussed with reference to international co-ordinated approaches.

\section{The Case for Hydrogen in the UK}

Since 1990, the UK has successfully reduced its territorial greenhouse gas emissions by $45.2 \%^{2}$ [12]. This is mainly attributable to the decrease in coal used for power generation coupled with an increased volume of renewable electricity generation. [13]. In 2019, onshore and offshore wind, bioenergy and waste and solar photovoltaics accounted for $19.8 \%, 11.5 \%$ and $4 \%$ of total UK electricity generation. Overall, renewable electricity generation accounted for $37.1 \%$ of the total UK electricity generation [14]. Despite this, to achieve ambitious net-zero targets, the decarbonisation of heavy emitting sectors must be addressed and confronted urgently [15]. In comparison to other sectors, carbon dioxide emissions from the transport and residential (domestic) sector have shown minor reductions since 1990; see Figure 1. Despite displaying considerable emission reductions over time, the energy supply and business and industrial sector still contribute substantially to overall UK emissions. Hydrogen can act as a substitute for conventional fossil fuels across many sectors including industry, transport, buildings and power $[3,9,16]$. This section provides an overview of the premise and opportunities for hydrogen across various UK sectors.

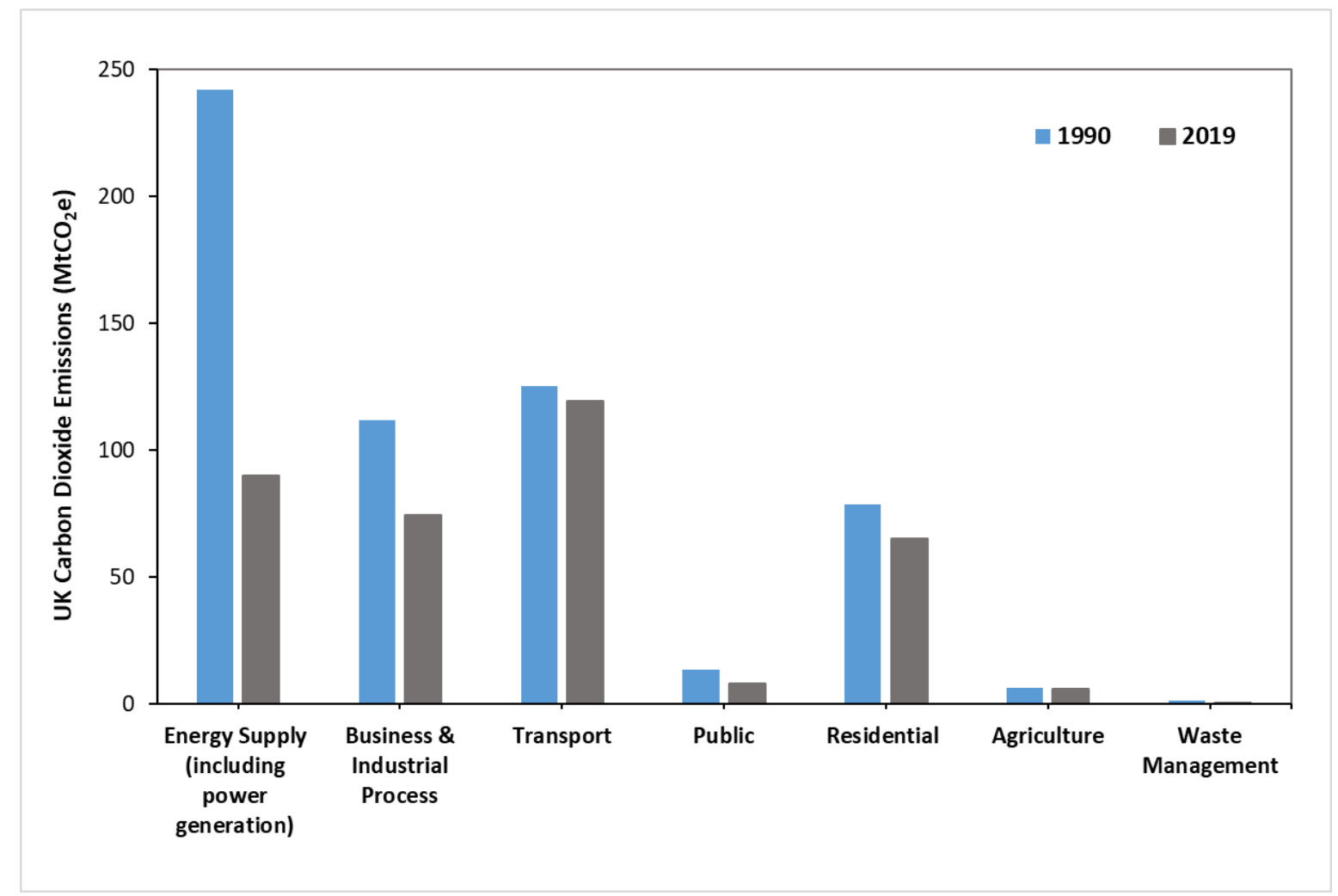

Figure 1 - Comparison of UK Carbon Dioxide Emissions per Sector in 1990 and 2019. Data Retrieved from [12]. [2 COLUMN FITTING IMAGE, COLOUR REQUIRED]. *Plotted using data from Appendix A: Table A.1

\subsection{Transportation}

Accounting for over one quarter of total UK $\mathrm{CO}_{2}$ emissions [12], the transport sector requires urgent, large-scale decarbonisation. In 2011, UK government announced that conventional car and van sales would end by 2040, with almost every car and van to be zero-emission by 2050 [17]. More recently,

\footnotetext{
${ }^{2}$ This is a provisional estimate for 2019. Final data for 2018 showed a 43\% decrease in emissions from 1990.
} 
a consultation was launched to seek views on whether this should be brought forward to 2035, or earlier, if feasible [18]. To tackle emissions in this sector, ultra-low emission vehicles (ULEVs) could be widely deployed. By definition, ULEVs are vehicles which emit less than $75 \mathrm{~g} \mathrm{CO}_{2}$ from the tailpipe, per kilometre travelled. As a result of recent technological advancements, this is expected to be modified to less than $50 \mathrm{~g} \mathrm{CO}_{2}$ from 2021 onwards [19].

\subsubsection{Applications of Hydrogen Vehicles in the Transport Sector}

Hydrogen fuel cell (HFC) vehicles, a type of ULEV, convert chemical energy into electrical energy using hydrogen and oxygen as reactants. The electrical power generated is supplied to the vehicle traction motor which initiates motion [20]. The tail pipe products from this reaction are water vapour and excess heat. Alongside emission reduction advantages, HFC vehicles also have health benefits due to the avoidance of air pollutants like those emitted by conventional petrol and diesel engines [21].

In comparison to alternative modes of low-carbon transport, HFC vehicles can address existing challenges such as land-use, air quality impacts, limited range and driving times [22]. They have received attention due to their long fuel range (approximately $500 \mathrm{~km}$ ) and short refuelling time (approximately 3 minutes) [23]. Furthermore, they can serve niche applications where vehicles are required to return to the same location for refuelling and require minimum refuelling time to avoid loss of earnings [24]. This could encompass vehicles such as buses, trains, forklifts, heavy-goods vehicles, ships and aviation applications.

\subsubsection{Cars and Light Goods Vehicles}

In 2018, the total number of first-time vehicle registrations of ULEVs in the UK was 63,991 . In comparison to 2010 , this is an increase of over $5000 \%$ [25]. Despite HFC vehicles being commercially available in the UK, battery electric vehicles (BEVs) currently dominate the ULEV market. From an economic stance, this is likely because they exhibit a price range similar to conventional petrol or diesel vehicles [26]. Despite providing a longer driving range and significantly shorter refuelling times than BEVs, HFC vehicles currently exhibit significantly higher capital costs [27]. Furthermore, there are only 16 operational hydrogen refuelling stations (HRSs) in the UK with only a further 3 planned [28]. Therefore, there are significant, nation-wide infrastructure requirements to allow HFC market progression.

\subsubsection{Buses}

If public transport usage increases by 2050, there will be a smaller requirement for electric vehicles on the road. This could help decrease transport emissions as well as indirectly mitigate against increases in congestion and accidents [29]. HFC buses have been successfully demonstrated in London since 2003. Initially, these buses had a range of only 125 miles [30]. Studies have shown that BEV buses are most efficient for short range journeys whereas HFC buses are best suited for long ranges [31]. In stage 2 of the UK Hydrogen for Transport Programme, f14m was awarded to numerous projects across the UK. The combined contribution of these projects includes 5 HRSs and 33 fuel cell electric buses [32]. More recently, Wrightbus unveiled plans to convert up to $10 \%$ of the UK bus fleet to zero-emission models. This will include up to 3,000 'Metrodecker' hydrogen fuel cell buses, which can carry more than 90 passengers and have a driving range between 200-250 miles [33]. 


\subsubsection{Trains}

In 2019, the UK's first train to be powered by hydrogen performed a test run. The HFC train, developed by engineers from University of Birmingham and Porterbrook, comprises hydrogen fuel tanks, a fuel cell and lithium batteries. This provides enough power for the train to travel 50-75 miles [34]. In the North West of the UK, Alstom are investigating the potential to convert Class 321 trains to run on hydrogen. This project could see hydrogen powered trains on UK rail infrastructure from 2021 [35]. Alstom have already successfully demonstrated hydrogen trains in Germany with the Coradia iLint.

\subsubsection{Medium and Heavy-Duty Trucks}

In the last 20 years, the freight industry has exhibited considerable economic growth, particularly concerning heavy-duty trucks. Trucks are competitive with other freight power-trains because of their ability to deliver directly to the desired destination in a short time [36]. The majority of medium-heavy duty trucks still run on diesel fuel and have negative environmental impacts in terms of emissions and air quality [37]. BEVs may not offer the required range to complete journeys without stopping and recharging [38]. This makes HFC trucks an attractive low-carbon option. One study found that HFC trucks could reduce well-to-wheel petroleum energy use by $98 \%$ and air emissions by $20-45 \%$ in comparison to diesel counterparts [37]. Despite being a key area of research, further R\&D is required for HFC trucks to become commercially available [36].

In the short-term, dual fuel combustion engines that can operate on both hydrogen and diesel could prove to be a competitive technology. These are already commercially available [39], and could act as an economical bridge solution for sustainable heavy-duty freight with notable emission reductions [36].

\subsubsection{Maritime Applications}

Emissions from international shipping cannot be ignored [15]. In UK territorial emission calculations, international shipping is not included [12]. However, it is estimated that shipping activities contribute to approximately $3-5 \%$ of global $\mathrm{CO}_{2}$ emissions whilst, simultaneously, emitting particulate matter (PM) and other hazardous air pollutants [40]. For the commercial maritime sector, HFC technologies are still at the investigation and demonstration phase [41]. Hydrogen also has the potential to be utilised in the maritime sector as a direct fuel, but this ultimately depends on the capability on producing clean, low-cost hydrogen. One study found that hydrogen fuelled transoceanic tankers emit approximately $0.98 \mathrm{~g} \mathrm{CO}_{2}$ per tonne-kilometre in comparison to approximately 5.33g per tonne-kilometre $\mathrm{CO}_{2 \mathrm{e}}$ emitted from conventional heavy fuel oil tankers [42].

\subsubsection{Aviation}

Approximately $2.5-5 \%$ of global energy is consumed by the aviation industry [43]. Similar to international shipping, international aviation emissions are exempt from UK territorial emissions [12]. The international aviation sector is expected to grow due to greater demands for air transport [44]. Therefore, $\mathrm{CO}_{2}$ emissions will continuously increase unless decarbonisation measures are adopted. Many challenges are left to address before hydrogen technologies are commercially deployed within the aviation sector. These include:

- The lack of infrastructure to provide hydrogen fuel for an energy carrier in the aviation industry

- The required alterations to aircraft design and airport operations

- The longer refuelling time of hydrogen in comparison to conventional aircraft fuels 
- The specific demand for high quality hydrogen to prevent efficiency reduction and catalyst poisoning within fuel cell systems

- The low power densities of fuel cells [43]

- The requirement for further studies on load, structure and aerodynamics due to the large volumes of hydrogen tanks [45].

\subsubsection{Material Handling}

Material handling equipment is an emerging market for HFC technologies. Examples of machinery include: counterbalanced forklifts, narrow aisle lift trucks, pallet jacks, and stock pickers [46]. Equipment could be deployed in food and retail distribution centres and manufacturing facilities [47]. HFCs can address problems exhibited with battery powered equipment such as the need for frequent battery charging and cool-down [46]. In the United States, more than 20,000 hydrogen fuel cell forklifts are operational [21]. Further information concerning the technical performance of hydrogen fuel cells in material handling equipment can be found at the following sources: [48-50].

\subsection{Domestic Sector}

In the UK, the domestic sector accounts for approximately $15 \%$ of total UK emissions [13]. Of all fuels supplied to this sector, natural gas accounts for approximately $65 \%$ of the total share [51]. Primarily, this is used for space and water heating. Continuing to match heating demands with large quantities of natural gas is incompatible with emission reduction targets unless alternative forms of low-carbon heating are adopted [52].

Heat pumps powered by renewable electricity could provide part of this solution. They are thought to be a feasible option for new buildings which are well insulated and where low temperature heating through the floor is possible [53]. However, most buildings are not compatible. Heat pumps face other challenges in terms of the capacity of existing electricity markets and the mismatch of available renewable energy; see Table 4 [54]. To explain further, Figure 2 shows the daily demand for natural gas in comparison to electricity and how much this varies across seasons. Approximately two thirds of this natural gas demand is used for space and water heating [55]. To address this heat demand utilising heat pumps, there would need to be a substantial increase in electricity generation capacity and storage [52]. Furthermore, as is the case for all electric technologies, the electricity utilised must be generated from a low-carbon source to have a carbon benefit.

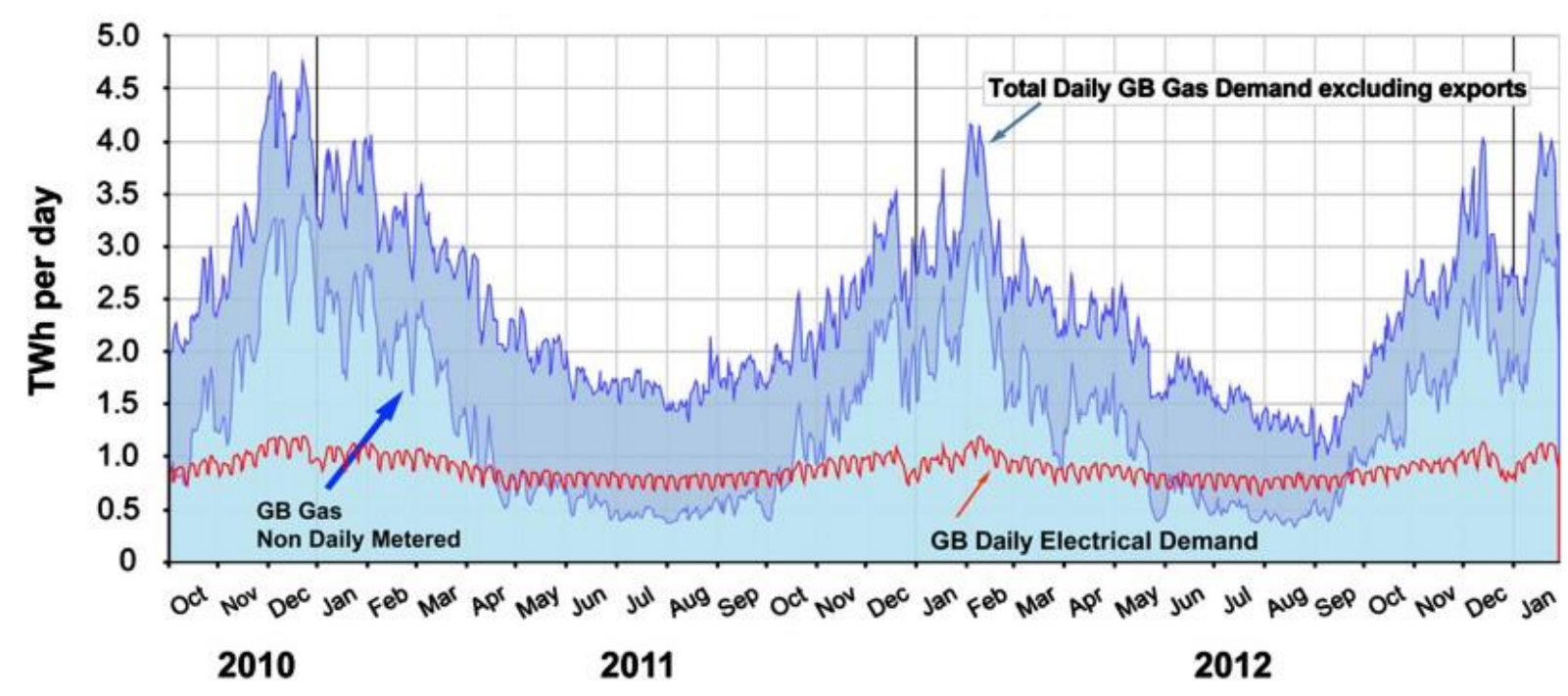

Figure 2 - Daily GB Gas and Electricity Demands (TWh). Retrieved from [55]. [2 COLUMN FITTING IMAGE, COLOUR REQUIRED]. 
Low-carbon hydrogen could also provide part of this solution, with potential to be produced at volumes sufficient to accommodate future heat demand [16]. A study conducted by KPMG identified that the incremental cost for an electric future ( $f 274-318 \mathrm{bn}$ ) to meet UK heat and energy demand would be nearly triple that of one with hydrogen as a primary fuel source ( $£ 104-122 \mathrm{bn})$ [56]. Please note that since this study was conducted, there have been developments in energy storage, electric vehicles and distributed generation technologies [57]. Furthermore, costs observed for renewable energy technologies have reached record lows [58]. In a modern setting, both factors could have implications on these conclusions drawn. For a brief overview of the advantages and disadvantages of other low-carbon heat options see Table 1.

\begin{tabular}{|c|c|c|}
\hline & Advantages & Disadvantages \\
\hline $\begin{array}{l}\text { Demand } \\
\text { Reduction }\end{array}$ & $\begin{array}{l}\text { + Low regret option } \\
+ \text { Energy bill reductions } \\
+ \text { Insulation and more efficient devices to } \\
\text { raise customer awareness }\end{array}$ & $\begin{array}{ll}\text { - } & \text { Low turnover rate of building } \\
\text { stock } \\
\text { - }\end{array}$ \\
\hline Heat Networks & $\begin{array}{l}\text { + Proven and widely used in some } \\
\text { countries } \\
+ \text { Good option for new builds and densely } \\
\text { populated regions } \\
+ \text { Could meet approximately } 10-20 \% \text { of UK } \\
\text { heating needs }\end{array}$ & $\begin{array}{ll}\text { - } & \text { High conversion cost and } \\
\text { disruption } \\
\text { - } \quad \text { Low-carbon heat sources required } \\
\text { - } \quad \text { Heat cannot be transported long } \\
\text { distances }\end{array}$ \\
\hline $\begin{array}{l}\text { Onsite } \\
\text { Renewables }\end{array}$ & $\begin{array}{l}\text { + Utilise local energy sources } \\
\text { + Reduces network dependence and } \\
\text { therefore minimises upgrade requirements } \\
\text { to network }\end{array}$ & $\begin{array}{ll}\text { - } & \text { Limited availability of renewables } \\
\text { - } & \text { Less cost-effective for small } \\
\text { schemes }\end{array}$ \\
\hline
\end{tabular}

Table 1 - Advantages and Disadvantages of Low-Carbon Heating Technologies. Retrieved from [22].

\subsubsection{Further Considerations for Hydrogen}

A study was conducted to assess the development of a hydrogen-fired supply chain in the UK [59]. It found that capital equipment costs for hydrogen-fired appliances could be $4 \mathrm{x}$ higher than existing natural gas appliances, for the first 1,000 units installed. At 100,000 units, this could reduce $1.5 x$ higher. In addition to economic barriers, other technical and market barriers identified are shown below:

\section{Technical Barriers}

- $\quad$ Specific designs for hydrogen appliances are limited in number

- $\quad$ Specific standards for the design of hydrogen appliances do not exist

- Burner technologies may not exhibit the same level of control or flame stability as natural gas alternatives

- Risk of flashback

- NOx emissions may be present at high temperatures without the use of catalysts

- $\quad$ Larger sized appliances may be needed due to hydrogens lower energy density than natural gas
- Suitable odorants have yet to be identified

- $\quad$ Standards for hydrogen purity have yet to be identified

- Currently there are no standards for installation of domestic hydrogen appliances

\section{Market Barriers}

- Lack of confidence in safe operation of appliances

- Lack of consumer awareness of the benefits of hydrogen

- Commercial boiler and catering market may be of lower interest to 
manufacturers as is a smaller sector compared to the domestic and industrial sector
- Considerable investment in infrastructure is required for product development which requires policy direction.

With regard to suitable hydrogen odourants, the following mixtures are under consideration: $78 \%$ tert-Butylthiol (TBM) and 22\% dimethyl sulphide (DMS) 3 , 34\% new blend and $64 \%$ hexane, $100 \%$ trinitrotoluene (TNT) and, specifically for fuel cell applications, 100\% 5-ethylidene-2-norbornene [60]. Concerning hydrogen purity, the draft standard shown in Table 2 has been proposed.

\begin{tabular}{cc}
\hline Content or Characteristic & Value \\
\hline Hydrogen Fuel Index (Minimum Mole Fraction) (\%) & 98 \\
Carbon Monoxide (ppm) & 100 \\
Hydrogen Sulphide Content (ppm) & $<3.5$ \\
Total Sulphur Content $(\mathrm{ppm})$ & $<35$ \\
Oxygen Content $(\%)$ & $<0.2$ \\
Hydrocarbon Dewpoint $\left({ }^{\circ} \mathrm{C}\right)$ & -2 \\
Water Dewpoint $\left({ }^{\circ} \mathrm{C}\right)$ & -10 \\
Sum of Methane, Carbon Dioxide and Total & $<1$ \\
Hydrocarbons (\%) & $<2$ \\
Sum of Argon, Nitrogen and Helium (\%) & $42-46$ \\
Wobbe Number Range $\left(\mathrm{MJm}^{-3}\right)$ & \\
\hline \hline
\end{tabular}

Table 2 - Draft Hydrogen Purity Standard Proposed in Work Package 2 of Hy4Heat Programme. Retrieved from [61].

If hydrogen is supplied, preliminarily as a blend with natural gas to UK households, this will change the thermo-physical properties of the existing gas supply, which may affect appliances. The injection of hydrogen into natural gas has been shown to lower the higher heating value (HHV), lower heating value (LHV) and Wobbe Index (WI) of the resultant gas mixture [62], which reduces the thermal energy supplied to end-consumers. Further properties to consider include flame characteristics, appliances performance, combustion noise, burner temperature and emissions [63]. For further technical assessments of hydrogen and natural gas mixtures please refer to the following sources: [63-66].

\subsection{Industrial Sector}

Natural gas is most commonly consumed within industry as a raw material or heat source and accounts for approximately $49 \%$ of the total fuel mix supplied [51]. Hydrogen can be utilised to help decarbonise emissions attributable to natural gas consumption. Evidence suggests that hydrogen could have an important role in decarbonising industrial heat in furnaces and kilns as well as industrial processes where sources of $\mathrm{CO}_{2}$ emissions are more distributed making carbon capture costly and impractical [67].

One UK study found that up to $30 \%$ of fuel consumed in energy-intensive processes could be matched by fuel switching. This could reduce $\mathrm{CO}_{2}$ emissions by $16 \mathrm{Mt}$ per annum [68]. Of the lowcarbon fuels analysed, hydrogen exhibited the highest technical potential. This was followed by biomass, waste materials and electricity. Despite this, hydrogen is not a 'silver bullet' for all processes, and in some cases, alternative fuels may be more appropriate. Another study assessed the appliance conversion cost of specific hydrogen-fired equipment in addition to its current technology readiness level (TRL) [69]; see Table 3.

\footnotetext{
${ }^{3}$ Also referred to as new blend.
} 


\begin{tabular}{|c|c|c|c|c|}
\hline $\begin{array}{l}\text { Hydrogen-Fired } \\
\text { Appliance Type }\end{array}$ & TRL & Example Equipment & $\begin{array}{l}\text { Applicable } \\
\text { Sector }\end{array}$ & $\begin{array}{c}\text { Appliance } \\
\text { Conversion Cost } \\
(\mathrm{fm})\end{array}$ \\
\hline & & 5MW Steam Boiler & Food and Drink & 0.45 \\
\hline & & 10MW Steam Boiler & Chemicals & 0.64 \\
\hline \multirow[t]{4}{*}{ Boiler } & 7 & & & \\
\hline & & 5MW Steam Boiler & Paper and Pulp & 0.49 \\
\hline & & 1.5MW Hot Water Boiler & $\begin{array}{l}\text { Elec \& Mech } \\
\text { Engineering }\end{array}$ & 0.22 \\
\hline & & 2MW Kiln & Ceramics & 0.24 \\
\hline \multirow[t]{3}{*}{ Kiln } & 4 & 10 MW Lime Kiln & Lime & 0.52 \\
\hline & & 10MW Furnace & Chemicals & 0.84 \\
\hline & & 20MW Furnace & Metals & 1.11 \\
\hline \multirow[t]{3}{*}{ Furnace } & 5 & 20MW Glass Furnace & Glass & 1.21 \\
\hline & & 1MW Oven & Food and Drink & 0.15 \\
\hline & & 2MW Oven & Vehicles & 0.21 \\
\hline Oven/ Dryer & 4 & 10MW Rotary Dryer & Minerals & 0.43 \\
\hline
\end{tabular}

Table 3 - TRL and Appliance Conversion Costs for Various Hydrogen- Fired Equipment - Retrieved from [69].

Under the UK Industrial Fuel Switching Programme, there are several on-going demonstration projects working to test the feasibility of hydrogen in industrial processes such as cement production, glass manufacturing, oil refining, beauty products manufacturing and calcium lime manufacturing [70]. For further information concerning alternative low-carbon fuels for industrial fuel switching, please refer to the following sources: [71-74].

\subsection{Power Generation}

Low-carbon electricity generation, including nuclear, accounts for nearly $53 \%$ of total electricity generation in the UK [75]. From this share, renewable sources account for $62 \%$. Two of the National Grid's Future Energy Scenario's conclude that UK electricity grid capacity must increase by over $100 \%$ by 2050 . Renewables are expected to account for the largest generation capacity [76]. At present, the intermittent availability of renewables presents problems as it varies significantly across seasons; see Table 4.

\begin{tabular}{ccccc}
\hline Generation (GWh) & $\mathbf{1}^{\text {st }}$ Quarter & $\mathbf{2}^{\text {nd }}$ Quarter & $\mathbf{3}^{\text {rd }}$ Quarter & $\mathbf{4}^{\text {th }}$ Quarter \\
& $\mathbf{2 0 1 8}$ & $\mathbf{2 0 1 8}$ & $\mathbf{2 0 1 8}$ & $\mathbf{2 0 1 8}$ \\
\hline Onshore Wind & 2370 & 1320 & 1291 & 2298 \\
Offshore Wind & 6948 & 4270 & 4350 & 7550 \\
Solar PV & 1569 & 4323 & 3996 & 1387 \\
\hline \hline
\end{tabular}

Table 4 - Quarterly Generation of Renewable Electricity in 2018 - Data Retrieved from [14]. 
Because renewable generation technologies cannot be controlled like thermal and nuclear power generation facilities, fossil-fuel resources are often required as reserve fuels to balance electricity supply and demand [77]. Most commonly, this demand is met by natural gas power generation plants. There is opportunity for hydrogen to cost-effectively replace natural gas back-up measures [67], and complement other low-carbon sources in the UK's ever increasing diversified electricity generation mix. Examples of future hydrogen power generation technologies include gas turbines [78-80] and stationary fuel cell systems [81-83].

\section{Hydrogen Technologies}

\subsection{Hydrogen Production}

At present, at least $96 \%$ of global hydrogen is produced from fossil fuel processing such as steam methane reforming (48\%), coal gasification (18\%) and the partial oxidation of oil (30\%) [84]. Only $4 \%$ is produced through electrolysis. Out of the total global consumption of gas and coal, hydrogen production accounts for $6 \%$ and $2 \%$ respectively. In terms of emissions, this equates to approximately $830 \mathrm{Mt}$ of $\mathrm{CO}_{2}$ per year [10]. Table 5 depicts the $\mathrm{CO}_{2}$ emissions associated with various fuel types, which can be utilised in hydrogen production.

\begin{tabular}{ccc}
\hline Fuel Type & $\mathrm{CO}_{2}$ Emissions (kg/kWh) & $\begin{array}{c}\mathrm{CO}_{2} \text { Emissions Relative to } \\
\text { Natural Gas }\end{array}$ \\
\hline Natural Gas & 0.20 & 1.00 \\
Fuel Oil & 0.28 & 1.40 \\
Hard Coal (Anthracite) & 0.34 & 1.70 \\
Brown Coal (Lignite) & 0.36 & 1.80 \\
Wood & 0.39 & 1.95 \\
\hline \hline
\end{tabular}

Table 5 - Comparison of Carbon Dioxide Emissions from Various Fuel Types - Adapted from [85].

Low-carbon hydrogen production from conventional fuels is possible with carbon capture and storage (CCS) technology and is commonly referred to as 'blue' hydrogen. For low-carbon hydrogen production, CCS is critical to avoid an overall net increase of $\mathrm{CO}_{2}$ emissions [24]. Whilst CCS technologies fall out of scope of this article, further information can be found at the following sources: $[86,87]$. Another form of hydrogen is 'green' hydrogen, which utilises renewable energy sources in its generation process.

In the Net-Zero technical report, the Committee on Climate Change (CCC) proposed a hydrogen scenario which claimed that UK hydrogen production must reach 270TWh per year to reach 2050 targets [16]. At present, UK hydrogen production amounts to approximately 27TWh per year from approximately 15 sites [84]. Therefore, to meet the required scale, production must increase by a factor of 10 within the next 30 years. It is envisioned that as much as $63 \%$ of future hydrogen could be produced through reforming with the remaining $37 \%$ supplied from electrolysis [16]. For this reason, this section focuses mainly on reforming and electrolysis. Biomass gasification and nuclear assisted hydrogen production are briefly highlighted as alternative low carbon technologies which may have a role in future UK hydrogen production. It is important to note that there are a wide range of hydrogen production technologies discussed throughout the literature which are not encompassed within this article. A holistic overview of these technologies can be found in the following articles: [88-92].

\subsubsection{Steam Methane Reforming (SMR)}


SMR technology has been implemented across industry since 1930 and is the most common hydrogen production process. With approximately 500 plants in operation globally [93], SMR dominates hydrogen production due to its mature status and ability to operate at near maximum theoretical limits [94]. Compared to alternative reforming technologies, like partial oxidation, SMR theoretically possesses the largest mole fraction of hydrogen in its product gas [95]. In this process, methane is mixed with steam and fed into a tubular reactor at temperatures of approximately $700^{\circ} \mathrm{C}$ and pressures of approximately 35 bar [88]. As a result, syngas (a mixture of $\mathrm{CO}$ and $\mathrm{H}_{2}$ ) is generated. This reaction is endothermic, and the required external energy input is supplied by natural gas. Following this, the resultant syngas normally undergoes two further water shift reactions: one at approximately $350-475^{\circ} \mathrm{C}$ and the other at $200-250^{\circ} \mathrm{C}$. The shifted syngas undergoes hydrogen purification (normally pressure swing adsorption (PSA)) where purities of up to $99.999 \%$ can be obtained [96-98]. To obtain a suitable $\mathrm{H}_{2} / \mathrm{CO}_{2}$ ratio, the tail gas from the PSA is often recycled to the reforming reactor [99]. On average, the energy requirement for SMR is approximately $46 \mathrm{kWh} / \mathrm{kg} \mathrm{H}$ which equates to approximately $30-35 \%$ of the total natural gas used for the process fuel $[22,88]$. The stochiometric equations for steam methane reforming are shown below [96]:

Steam Methane Reforming Reaction:

$$
\mathrm{CH}_{4}+\mathrm{H}_{2} \mathrm{O} \leftrightarrow \mathrm{CO}+3 \mathrm{H}_{2} \quad \Delta \mathrm{H}^{\circ}=198 \mathrm{~kJ} \mathrm{~mol}^{-1}
$$

Water Gas Shift Reaction:

$$
\mathrm{CO}+\mathrm{H}_{2} \mathrm{O} \leftrightarrow \mathrm{CO}_{2}+\mathrm{H}_{2} \quad \Delta \mathrm{H}^{\circ}=-41 \mathrm{~kJ} \mathrm{~mol}^{-1}
$$

\subsubsection{Auto-Thermal Reforming (ATR)}

Originally, this process was developed to perform partial-oxidation (POX) and SMR in one single reactor. By combining these processes, ATR addresses the issue of low hydrogen yield associated with POX and the slow start-up and response times associated with SMR [100]. In this process, natural gas and steam are mixed with oxygen and/or air. Differing from SMR, the energy required to drive the reaction is supplied from oxygen as opposed to natural gas [101]. Like SMR, the resultant syngas undergoes water gas shift reactions and the hydrogen is separated using PSA. Operating at higher temperatures and pressures than SMR, ATR produces higher pressure syngas at a lower steam to carbon ratio. The reduced steam requirements improve overall process efficiency. Furthermore, high pressure hydrogen, in the syngas, reduces the requirement for additional downstream hydrogen compression [102].

\subsection{Low-Carbon Hydrogen (LCH)}

The LCH system, coined by Johnson Matthey, differs from the traditional ATR system by coupling the ATR reactor with a gas heated reactor (GHR) [103]. In this process, natural gas undergoes an initial reforming reaction with steam in the GHR prior to entering an ATR unit. This then reacts further with pure $\mathrm{O}_{2}$ in the ATR unit, where the final reforming reaction takes place. Resultant syngas travels back through the GHR to provide heat for the initial reforming reaction before undergoing water gas shift reactions and PSA for hydrogen separation [101]. Though CCS falls out of scope of this article, it is important to note that LCH technology can capture a greater percentage of carbon than SMR [11]. For further information, please refer to the following source: [104].

\subsubsection{Electrolysis}


Electrolytic hydrogen production systems consist of two electrodes which are separated and submerged into an electrolyte which allows a current to flow. Water and electricity are used as feedstocks. Water is separated into hydrogen and oxygen as a result of the direct current $[105,106]$. Across the literature, alkaline, polymer exchange membranes (PEM) and solid oxide electrolysis cells (SOEC) are analysed most and will therefore be the only electrolytic systems reviewed in this article. To produce 'green' hydrogen from electrolysis, the electricity supplied must have been generated from renewable energy sources.

\subsubsection{Alkaline Electrolysis}

Alkaline electrolysis is the most mature of the three. The largest plant observed a production rate of approximately $1,200 \mathrm{~kg} \mathrm{H}_{2}$ per hour however this is currently mothballed [107]. Despite this technology being widely commercialised, it has several drawbacks in comparison to alternative electrolytic systems such as low gas purity, low operational pressures and higher energy consumption [108]. As a result of low operational pressures, additional hydrogen compression is required for downstream applications.

\subsubsection{Polymer Exchange Membrane Electrolysis}

Compared to alkaline electrolysis, PEM systems can operate at higher pressures. Furthermore, they exhibit rapid dispatchability and turn down times and have the capability to operate under a wide range of dynamics, making them better suited for coupling with renewable energy sources for lowcarbon hydrogen production [109]. Though still in the early stages of market penetration, PEM systems are expected to achieve hydrogen production in the giga-watt magnitude in coming years [110]. This will be subject to addressing commercial barriers such as high production costs associated with electrode construction materials and efficiency maintenance over the life-cycle of the technology [108]. Further research into catalyst and membrane materials is encouraged to enable the cost-effective, wide-spread application of this technology [111].

\subsubsection{Solid Oxide Electrolysis Cells}

Though still operating at a lab-scale capacity (10kW to 100kW) [107], SOECs have received increased attention due to their capability to operate at higher temperatures than other electrolytic systems. This warrants the opportunity for such systems to be integrated into industrial processes which produce large volumes of waste heat [108]. Other advantageous characteristics include the potential to act in reverse mode (as a fuel cell) and the potential to be utilised in co-electrolysis to produce syngas [112]. Challenges such as poor long-term cell stability and material problems have prohibited the wide-application and commercialisation of these cells [113]. Further information concerning the technical parameters of each electrolytic system is shown in Table 6.

\begin{tabular}{|c|c|c|c|}
\hline Technical Parameter & Alkaline & PEM & SOEC \\
\hline Temperature $\left({ }^{\circ} \mathrm{C}\right)$ & $60-80$ & $50-80$ & $650-1000$ \\
\hline Pressure (bar) & $<30$ & $<200$ & $<25$ \\
\hline Cell Area $\left(\mathrm{m}^{2}\right)$ & $<4$ & $<0.3$ & $<0.01$ \\
\hline $\begin{array}{l}\text { System Energy Consumption } \\
\left(\mathrm{kWh}_{\mathrm{el}} / \mathrm{Nm}^{3}{ }_{\mathrm{H} 2}\right)\end{array}$ & $4.5-6.6$ & $4.2-6.6$ & $>3.7$ \\
\hline $\mathrm{H}_{2}$ Production Rate $\left(\mathrm{Nm}^{3} / \mathrm{h}\right)$ & $<760$ & $<40$ & $<40$ \\
\hline $\mathrm{H}_{2}$ Purity (\%) & $>99.5$ & 99.99 & 99.9 \\
\hline Stack Lifetime (h) & $60000-90000$ & $20000-60000$ & $<10000$ \\
\hline
\end{tabular}


Efficiency (\%)

Cold Start Time (min)
$56-79$

$<60$
$55-69$

$<20$
$88-105 \%[114]$

$<60$

Table 6 - Typical Operating Parameters of Alkaline, PEM and SOEC systems [115, 116].

\subsubsection{Power to X (PtX) Systems}

In future, electrolysis could enable the coupling of the electricity, chemical, mobility and heating sectors through PtX systems [117]. Such systems consist of the conversion of renewable electricity, through electrolysis, into valuable, low-carbon gases, fuels and chemicals. Whilst this falls out of scope of this review article, further information can be found at the following references: [118-121].

\subsubsection{Alternative Low-Carbon Hydrogen Production Technologies}

This section explores hydrogen production technologies which, in future, could be suitable in a UK setting.

\subsubsection{Biomass Gasification}

Biomass gasification is the thermochemical conversion of biomass into syngas through a gasification medium such as air, oxygen and/ or steam [88]. Typically, gasification reactions occur at temperatures above $700{ }^{\circ} \mathrm{C}$ [89], and exhibit efficiencies of approximately $44-48 \%$ [22]. Prior to undergoing water gas shift reactions and hydrogen separation, similar to reforming processes, an extra step is often required to reform additional hydrocarbons still present in the syngas [122].

At present, there are many operational facilities which produce heat and/or power using biomass gasification, which could give rise to hydrogen production capabilities [123]. If combined with CCS technology, hydrogen production from biomass gasification has the potential to be carbon negative. This is referred to as bioenergy with carbon capture and storage (BECCS). It is envisioned that by 2050 , global deployment of BECCS technology could result in the removal of up to $16 \mathrm{Gt} \mathrm{CO}_{2}$ per year [124]. Though, this is accompanied by a loss in process efficiency and additional CAPEX and OPEX in comparison to alternative reforming technologies [125].

\subsubsection{Nuclear Assisted Hydrogen Production}

Nuclear radiation energy from fission and fusion reactors can provide process steam, sensible heat and/ or electricity required to power various hydrogen production technologies. Radiation energy can be converted into high temperature heat for thermal hydrogen production or used to generate power for electric hydrogen production [126]. Out of the several possible hydrogen production technologies, electrolysis and thermolysis show the most potential [127]. Thermolysis encompasses the thermo-chemical splitting of water and is carried out using thermo-chemical cycles such as sulphur-iodine, hybrid copper-chloride and sodium-manganese.

\subsubsection{Economic Considerations of Hydrogen Production Technologies}

Figure 3 shows the results of a basic economic analysis performed on the hydrogen production technologies discussed throughout this article. The average cost of hydrogen $\left(f_{2019} / \mathrm{kg}\right)$ and CAPEX $\left(f_{2019} / \mathrm{kW}\right)$ were calculated. All data was collected from sources analysed throughout this section. Further information concerning the methodology, conversion factors and data used can be found in 
Appendix B as well as an overview of the specific process units incorporated within overall CCS cost assessments.

\subsubsection{Cost of Hydrogen}

The lowest average cost of hydrogen was from ATR, followed by SMR. Electrolysis showed the greatest hydrogen production cost. These results are expected as electricity is the most expensive feedstock [93]. There was insufficient economic data available for biomass gasification with CCS and LCH technologies. For this reason, these technologies were not included in this analysis.

\subsubsection{CAPEX}

With respect to CAPEX, biomass gasification was most expensive, especially with CCS. SMR exhibited the lowest cost. However, this process is not low carbon. To avoid an overall net-increase in $\mathrm{CO}_{2}$ emissions from future hydrogen production, CCS is critical. Biomass gasification and nuclear assisted hydrogen production showed the greatest variation of data throughout the literature. This is most likely due to the immaturity of these processes in comparison to SMR where accurate values can be obtained. There was insufficient economic data available for LCH and LCH with CCS; with only one value calculated for each. For this reason, these technologies were not included in this analysis. These values are located in Appendix B: Table B.3.

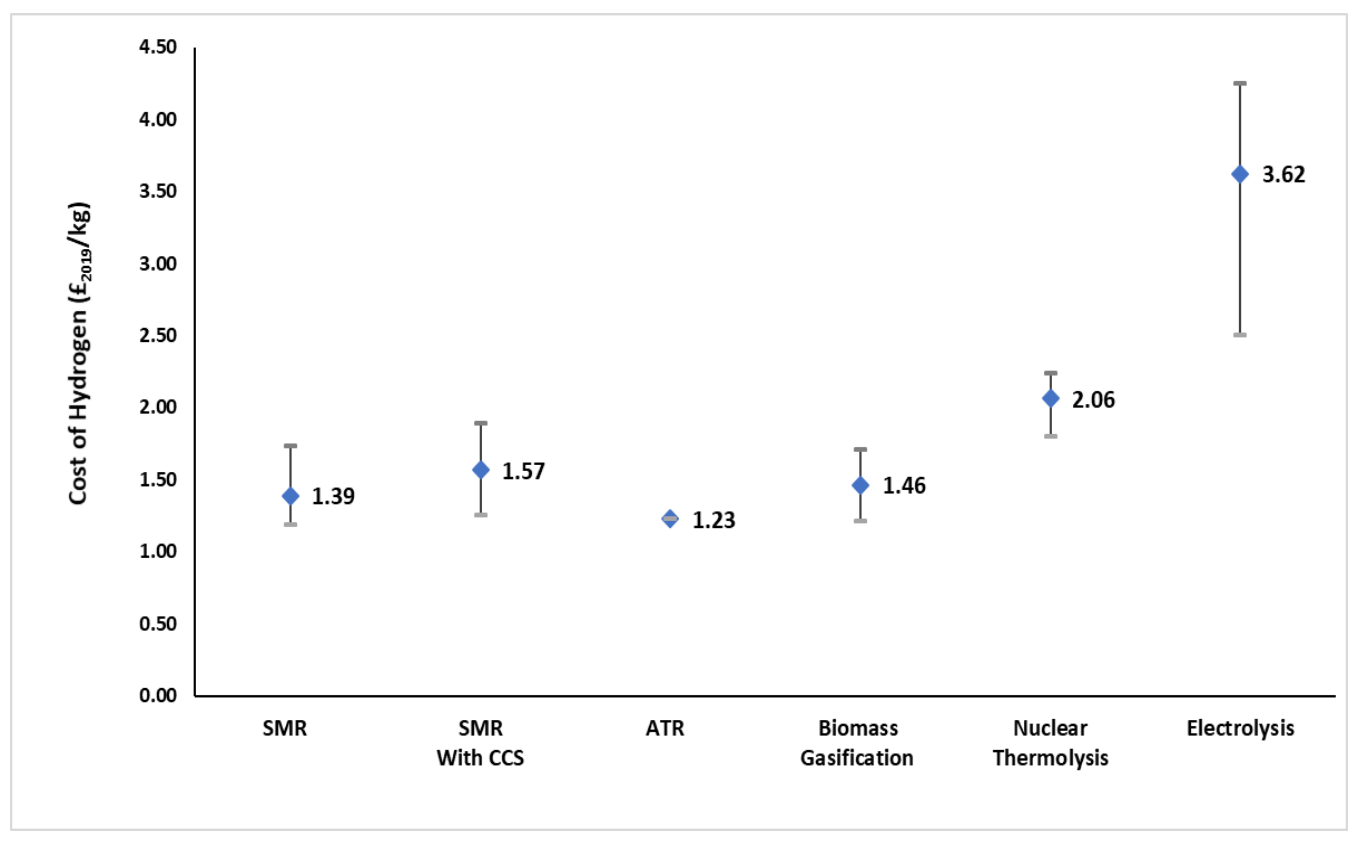




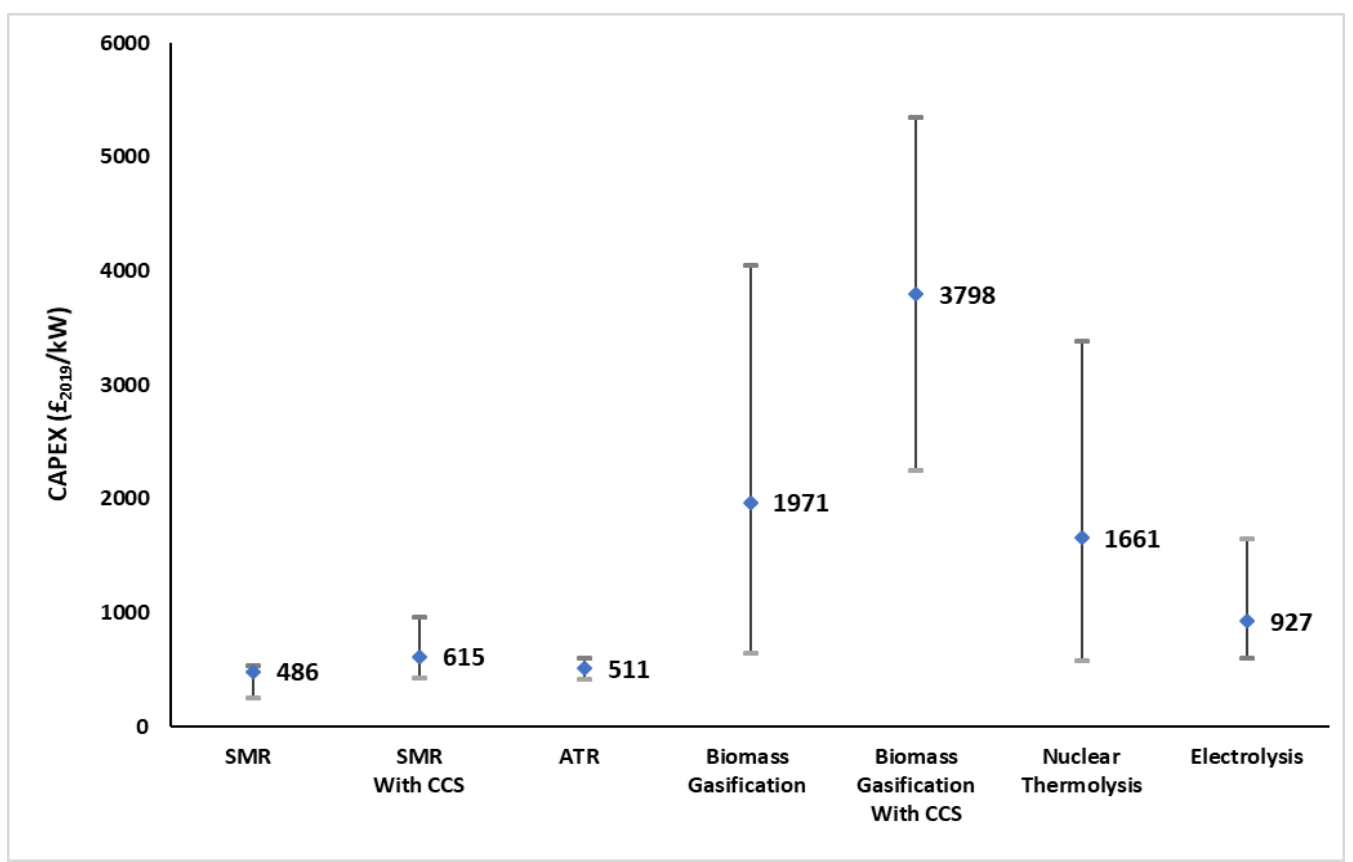

Figure 3 - Average Cost of Hydrogen and CAPEX for Various Hydrogen Production Technologies from Sources Analysed through Article. [2 COLUMN FITTING IMAGE, COLOUR REQUIRED].

\subsection{Hydrogen Storage}

As demand for hydrogen increases, it is vital that an array of hydrogen storage mechanisms are available to accommodate the volume of hydrogen production [128]. Characteristics such as volumetric density, required energy input and efficiency of operation govern the desirability of storage technologies [129]. This section provides an overview of several hydrogen storage mediums which are discussed most frequently throughout the literature.

\subsubsection{Challenges with Hydrogen Storage}

Gravimetric energy density refers to the amount of energy stored within a given mass and volumetric energy density refers to the amount of energy stored within a given volume. As shown in Table 7, hydrogen has a considerably greater gravimetric energy density than alternative fuels. However, the mass of hydrogen per given volume is lower than natural gas and gasoline. Because of its low volumetric energy density, hydrogen storage options typically require large volume systems [130].

\begin{tabular}{cccc}
\hline Characteristic & Hydrogen & Natural Gas & Gasoline \\
\hline $\begin{array}{c}\text { Lower heating value, LHV (MJ/kg) } \\
\text { Higher heating value, HHV (MJ/kg) }\end{array}$ & 119.96 & 47.13 & 43.44 \\
$\begin{array}{c}\text { Density at } 20^{\circ} \mathrm{C}, 1 \mathrm{~atm} \\
\left(\mathrm{~kg} / \mathrm{m}^{3}\right) \\
\begin{array}{c}\text { Liquid Density } \\
\left(\mathrm{kg} / \mathrm{m}^{3}\right)\end{array}\end{array}$ & 0.08 & 52.21 & 46.52 \\
\hline \hline
\end{tabular}

Table 7 - Comparison of Characteristics of Conventional Fuels [131, 132] 


\subsubsection{Physical Hydrogen Storage}

To increase the density of hydrogen from that exhibited in standard conditions, there are numerous options such as compression, liquefaction and a combination of the two. The typical conditions of each of these and associated densities are outlined in Table 8. This is referred to as physical storage.

\begin{tabular}{cccc}
\hline $\begin{array}{c}\text { Physical Hydrogen } \\
\text { Storage Type }\end{array}$ & Pressure (bar) & Temperature $\left({ }^{\circ} \mathrm{C}\right)$ & Density $\left(\mathbf{k g} / \mathbf{m}^{\mathbf{3}}\right)$ \\
\hline $\mathrm{CGH}_{2}$ & 300 & 15 & 23 \\
$\mathrm{CGH}_{2}$ & 700 & 15 & 41 \\
$\mathrm{LH}_{2}$ & 1 & -253 & 70 \\
$\mathrm{CcH}_{2}$ & 300 & -23.5 & 80 \\
\hline \hline
\end{tabular}

Table 8 - Density of Hydrogen for Various Types of Physical Hydrogen Storage Where CGH2 = Compressed Gaseous Hydrogen, LH2 = Liquid Hydrogen and CCH2 = Cryo-compressed Hydrogen [133].

\subsubsection{Compressed Gaseous Hydrogen $\left(\mathrm{CGH}_{2}\right)$}

Hydrogen compression can be achieved using reciprocation compressors which display a maximum operating pressure of approximately 1,000 bar. In theory, rotary displacement machines could also be utilised though this is not common practice [128]. At present, compressed gas is the most wellestablished hydrogen storage medium [134]. Typically, storage vessels for gaseous hydrogen have a working pressure of 200-300 bar for stationary applications and 700 bar for automotive applications [135]. Compressed storage systems have distinct advantages for the automotive sector as they possess the ability to rapidly refuel vehicles in approximately 3-5 minutes [136]. However, with additional pressure allowances, weight and cost penalties are incurred.

\subsection{Salt Caverns}

For large scale gaseous hydrogen storage, salt caverns could provide an energy storage capacity within the $100 \mathrm{GWh}$ range, geometrical volumes of up to $700,000 \mathrm{~m}^{3}$ and working pressures of approximately 200 bar [137]. Salt cavern storage could be utilised to balance fluctuations in hydrogen demand whilst acting as a power store for the regeneration of electricity from intermittent renewable energy sources [138]. This storage vector is desirable due to low construction costs, low leakage rates, fast withdrawal and injection rates and minimal risks of hydrogen contamination [139].

\subsubsection{Liquid Hydrogen $\left(\mathrm{LH}_{2}\right)$}

Liquid hydrogen is a preferred option for high purity, bulk hydrogen storage due to its higher density than gaseous alternatives [136]. However, the liquefaction process is considerably more energy intensive. This is because of the low boiling point of hydrogen $\left(-253^{\circ} \mathrm{C}\right.$ at 1 bar $)$ and the requirement for pre-cooling of the liquefaction process [139]. Despite liquefiers being commercially available, this process is only recommended for large-scale systems to limit efficiency losses [128]. Liquid hydrogen also has additional safety challenges. If leakage occurs with gaseous hydrogen, it will rise in air and dissipate quickly due to differences in buoyancy where-as liquid hydrogen will freeze surrounding air and accumulate at ground level [140]. Liquid hydrogen is best suited for circumstances where highenergy density is required and boil-off is less of a concern [134].

\subsubsection{Cryo-compressed $\left(\mathrm{CcH}_{2}\right)$}


$\mathrm{CcH}_{2}$ systems exhibit higher hydrogen density in comparison to $\mathrm{CGH}_{2}$ and $\mathrm{LH}_{2}$ and are recognised as a promising storage vector. Most commonly, the performance of cryo-compressed hydrogen has been assessed for automotive applications [141-143]. The most discussed system throughout the literature is the 'Gen-3 cryo-compressed $\mathrm{H}_{2}$ storage tank system' for which further information can be found at the following source: [144]. Recent research for $\mathrm{CcH}_{2}$ systems has shown a $91 \%$ improvement in gravimetric capacity and a $21 \%$ lower system cost [141]. One advantage of the $\mathrm{CcH}_{2}$ system is the increased dormancy period within the storage vessel. This means that hydrogen can be stored in cryo-compressed conditions without evaporation losses for longer time periods than alternative options [144]. Technical components concerning each physical storage method mentioned are shown in Table 9.

\begin{tabular}{|c|c|c|c|c|}
\hline Storage Type & $\begin{array}{c}\text { Energy Demand - } \\
\text { for Conversion } \\
\text { from Ambient } \\
\text { Conditions } \\
(\mathrm{kW} / \mathrm{kg} \mathrm{H})\end{array}$ & $\begin{array}{l}\text { Overall Efficiency } \\
\text { (\%) }\end{array}$ & $\begin{array}{c}\text { Vessel Material/ } \\
\text { Design }\end{array}$ & $\begin{array}{c}\text { Volumetric } \\
\text { Density }^{4}(\mathrm{MJ} / \mathrm{L})\end{array}$ \\
\hline \multirow{2}{*}{$\begin{array}{c}\text { Compressed } \\
\text { Gaseous Hydrogen }\end{array}$} & 2.23 (300 bar) [145] & $\begin{array}{l}52 \text { (approx. } 20 \% \text { of } \\
\text { energy from initial } \\
\text { hydrogen supplied) } \\
{[145]}\end{array}$ & Steel Cylinders [146] & $2.9-4.9$ [146] [134] \\
\hline & 3.00 (700 bar) [145] & $\begin{array}{c}49 \text { (approx. } 20 \% \text { of } \\
\text { energy from initial } \\
\text { hydrogen supplied) } \\
{[145]}\end{array}$ & $\begin{array}{c}\text { Composite Tanks } \\
\text { (Generally Carbon } \\
\text { Fibre with Polymer } \\
\text { Liner) [147] }\end{array}$ & $2.9-4.9$ [146] [134] \\
\hline Liquid Hydrogen & $10.00[148]$ & $\begin{array}{c}\text { 30-40 (approx. } 40 \% \\
\text { of energy from initial } \\
\text { hydrogen supplied) } \\
{[149]}\end{array}$ & $\begin{array}{l}\text { Steel vessel with } \\
\text { double hull with } \\
\text { vacuum between } \\
\text { inner and outer } \\
\text { vessel to avoid } \\
\text { increased } \\
\text { evaporation [146] }\end{array}$ & $6.4[134]$ \\
\hline $\begin{array}{c}\text { Cryo-Compressed } \\
\text { Hydrogen }\end{array}$ & 8.20 [150] & $\begin{array}{c}33 \text { (based on } 52 \% \\
\text { compression } \\
\text { efficiency and } 64.3 \% \\
\text { vessel efficiency) } \\
{[150]}\end{array}$ & $\begin{array}{c}\text { Gen-3 cryo- } \\
\text { compressed H2 } \\
\text { storage tank system } \\
{[150]}\end{array}$ & $4.0[150]$ \\
\hline
\end{tabular}

Table 9 - Outline of Technical Components of Various Physical Hydrogen Storage Options.

\subsubsection{Material-Based Hydrogen Storage}

Most material-based hydrogen storage systems are in the early stages of development and face challenges such as high process costs and long charging/ discharging times [133]. For this reason, several technologies will be referenced to highlight potential future storage technologies but will not be discussed in as much detail as the physical storage systems.

Despite these drawbacks, material storage systems do have clear advantages in terms of safety. For example, hydrogen does not readily discharge from storage materials thus eliminating some of the safety implications previously highlighted. Furthermore, they have high storage densities which range from $70-150 \mathrm{kgH}_{2} / \mathrm{m}^{3}$ [133]. This is considerably higher than physical based systems; see Table 8.

\footnotetext{
${ }^{4} 1 \mathrm{~L}=0.001 \mathrm{~m}^{3}$.
} 


\subsubsection{Liquid Organic Hydrogen Carrier (LOHC)}

In LOHC storage, hydrogen is loaded onto unsaturated organic compounds through an exothermic hydrogenation reaction. Typically, this occurs at elevated temperatures and pressures [135]. For the release of hydrogen (dehydrogenation), elevated temperatures within the range of $200-450^{\circ} \mathrm{C}$ are required [151].

\subsubsection{Metal Hydride}

In this storage medium, molecular hydrogen gas is split into its atomic form on the surface of a metal and then diffuses into its atomic structure. Metal hydride formations can be achieved through the following reversible reaction [152]:

$$
M+\frac{x}{2} H_{2} \leftrightarrow M H_{x}+Q
$$

Where $M$ refers to a metal, $Q$ is the heat of reaction and $x$ is a stoichiometric co-efficient.

Despite the forward reaction being exothermic, the absorption rate of hydrogen is considerably low. To achieve storage capacities of approximately $5-7 \%$, the reaction requires temperatures around $2500^{\circ} \mathrm{C}[153]$. For hydrogen release, a temperature of approximately $120-200^{\circ} \mathrm{C}$ is required.

For metal hydride systems, the mass of hydrogen uptake is, on average, $5 w t \%$ [133]. This means that $5 \mathrm{~kg}$ of hydrogen can be stored for every $100 \mathrm{~kg}$ of metal. Therefore, with increased storage demands, the amount of host material required will significantly increase. This will have associated cost penalties.

\subsubsection{Chemical}

Examples of chemical storage of hydrogen include ammonia $\left(\mathrm{NH}_{3}\right)$, and formic acid $(\mathrm{HCOOH})$. Ammonia can be stored and transported safely at low pressures. In comparison to formic acid, ammonia releases zero $\mathrm{CO}_{2}$ emissions upon dehydrogenation and exhibits a greater gravimetric energy density than observed in LOHCs [133]. Formic acid contains $53 \mathrm{~kg} / \mathrm{m}^{3}$ of hydrogen with a density of $4.3 w t \%$ at ambient conditions [153].

\subsubsection{Metal Organic Framework (MOF)}

In physisorption systems, like MOFs, hydrogen physically adsorbs to host materials, which possess a large surface area. The temperatures required for desorption reactions are generally significantly lower than hydrogen discharge and dehydrogenation reactions in other material-based storage systems [133]. In addition to this, they exhibit uniform size, large void space and acceptable thermal stability [153]. These systems remain furthest away from practical implementation.

\subsection{Hydrogen Delivery Systems}

The most economic hydrogen transportation network will be dictated by specific national, regional and local resources and conditions [154]. In initial phases of hydrogen networks, where demonstration/pilot projects are present, small-scale transportation methods could be more economically viable. Once hydrogen markets are developed and there is increased demand, largescale transportation methods will be more economically viable. This section provides an overview of the technologies available across a range of delivery capabilities.

\subsubsection{Pipeline}


Across the globe, approximately $4,500 \mathrm{~km}$ of hydrogen pipelines are installed. Some of which, have been in operation for over 60 years $[155,156]$. Typically, hydrogen pipelines have diameters of 25 $30 \mathrm{~cm}$ and operate between 10-20 bar [136]. In comparison to conventional gas pipelines, hydrogen pipelines are more capital intensive due to the requirement of greater diameters [157]. Other additional costs are incurred through welding procedures, leak testing and compression due to the low molecular weight of hydrogen and its associated diffusivity [66].

\subsubsection{Blend Vs. $100 \%$}

The blending of hydrogen into existing natural gas pipelines is being explored, and tested, in the UK and other countries [158]. This warrants cost reduction by utilising existing transmission and distribution pipeline infrastructure. In the short term, it envisioned that hydrogen could be blended into most networks at $6 \%$ volume. By 2030 , operators recommend a target capacity of $10 \%$ and $20 \%$ thereafter with limited changes to infrastructure [159]. Some key considerations associated with hydrogen blending are as follows:

. Appropriate hydrogen blend concentration could vary considerably between pipeline networks . Additional monitoring and maintenance services are likely to be necessary . Infrastructure upgrade may be required due to the degradation of metal pipes . Permeation times of hydrogen are 4-5 times faster than methane in polymer pipes and may result in leakage

. Separation technologies could be required to extract hydrogen from mixtures in natural gas pipelines dependent on end-use application [160, 161].

\subsubsection{Road Transportation}

At present, hydrogen is transported via road using high pressure gaseous tube trailers and cryogenic liquid cargo trailers. The transportation of hydrogen in LOHC trailers is also gaining traction in recent literature and its potential is well received $[135,162,163]$. LOHC trailers provide an intermediate storage capacity between gaseous and liquid trailers. Unlike pipelines, road transportation systems cannot accommodate increased hydrogen demand. Therefore, as hydrogen demand increases, capital investments of infrastructure, labour costs and logistics costs also increase. However, for initial developments of hydrogen networks, road transport is generally considered the most economic [164]. A comparative overview of these three systems is given in Table 10 and an overview of all delivery systems discussed is given in Table 11.

\begin{tabular}{cccc}
\cline { 2 - 3 } & $\mathbf{G H}_{\mathbf{2}}$ Trailer & LH $_{\mathbf{2}}$ Trailer & LOHC Trailer \\
\hline Capacity (kg) & $670[135]$ & $4000[165]$ & $1800[135]$ \\
Loading Time (h) & $1.5[135]$ & $3.0[135]$ & $1.5[135]$ \\
Operating Pressure & $15-250[135]$ & Near Atmospheric [135] & Near Atmospheric [135] \\
(bar) & & Outer Shell: Carbon & \\
& & Steel SA516 & Steel [135] \\
Construction Material & 34CrMo Steel Alloy & Inner Shell: Stainless & \\
& & Steel Type 304 [165] &
\end{tabular}

Please note that these values vary throughout literature and should only be taken as a rough indication.

Table 10 - Comparative Overview of Various Parameters for Different Options of Road Transportation. 


\begin{tabular}{|c|c|c|c|c|c|c|}
\hline $\begin{array}{l}\text { Delivery } \\
\text { Option }\end{array}$ & Capacity & Fixed Costs & Variable Costs & $\begin{array}{l}\text { Transport } \\
\text { Distance }\end{array}$ & $\begin{array}{c}\text { Technology } \\
\text { Status }\end{array}$ & Advantages (+) and Disadvantages (-) \\
\hline Pipeline & $\mathrm{H}$ & $\mathrm{H}$ & L & $\mathrm{H}$ & Available & $\begin{array}{l}\text { (+) Have shown safe operation globally for over } 60 \text { years } \\
\text { [156] } \\
\begin{array}{c}\text { (-) Increased cost associated with welding, leak prevention } \\
\text { and compression [66] }\end{array} \\
\text { (+) Offers further storage opportunity through line- } \\
\quad \text { packing [166] } \\
\text { (-) Potential pipeline failure due to embrittlement which } \\
\text { could result in jet fires, flash fires and explosions [167] }\end{array}$ \\
\hline $\mathrm{GH}_{2}$ Trailer & L & L & $\mathrm{H}$ & L & Mature & $\begin{array}{l}\text { (+) Currently the most economic form of hydrogen road } \\
\text { transportation [164] } \\
\text { (-) Trailers have fixed capacities and cannot accommodate } \\
\text { an increased hydrogen demand without increased capital } \\
\text { investments in infrastructure, labour and logistic costs } \\
\text { [164] } \\
\text { (+) Composite construction materials allow for a greater } \\
\text { capacity of hydrogen [135] } \\
\text { (-) Composite materials are accompanied with greater } \\
\text { capital investments [135] }\end{array}$ \\
\hline $\mathrm{LH}_{2}$ Trailer & M & $M$ & M & $\mathrm{H}$ & Available & $\begin{array}{c}\text { (+) Economically suitable for long transportation } \\
\text { distances, IE) ships and trains [135] } \\
\text { (-) Net-loss in payload due to hydrogen boil-off [136] } \\
\text { (-) Longer average loading times compared to alternative } \\
\text { technologies [135] }\end{array}$ \\
\hline LOHC Trailer & L-M & L [151] & $\mathrm{H}$ & M [151] & Emerging & 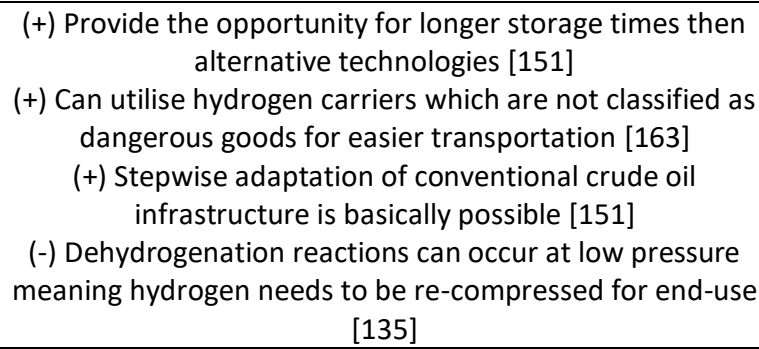 \\
\hline
\end{tabular}

Table 11 - Overview of Hydrogen Delivery Options where L = Low, M = Medium and H = High - Adapted and Extended from [168]. 


\section{Hydrogen Policy in the UK}

Given that hydrogen could play a significant role in UK decarbonisation [169], it is important that stronger policy measures are adopted to ensure net-zero emission targets are met. Across the literature, there are a lack of academic papers which review hydrogen policy in a UK setting. For those which do, many focus mainly on its implications and focus less on existing policy mechanisms [170-172]. This section highlights existing UK policy measures which are supportive of hydrogen as well as resultant policy recommendations.

\subsection{Emission Targets}

Emission targets specify reduction levels to be achieved within a specified timeframe [173]. This subsection highlights various emission targets which the UK have committed to. Whilst not specific to hydrogen technologies, this policy mechanism encourages the deployment of low-carbon technologies.

\subsubsection{Kyoto Protocol}

The Kyoto Protocol sets international emission reduction targets based on 1990 levels which are legally binding [174]. For the first commitment period (2008-2012) the UK surpassed the target of $12.5 \%$ and successfully reduced emissions by $22 \%$ [175]. However, not all industrialised countries committed to these targets and there was an overall net increase in global $\mathrm{CO}_{2}$ emissions [176]. Twenty-nine countries are committed to the second commitment period (2013-2020), which has an emission reduction target of $20 \%$. All are on track to reach or surpass this target [177].

\subsubsection{The Climate Change Act (2050 Target Amendment)}

The Climate Change Act seeks to reduce UK greenhouse gas emissions by at least $100 \%$ relative to 1990 levels [178]. Previously, this target was 80\% until later amended in June 2019.

\subsubsection{Carbon Budgets}

Carbon budgets have been implemented to restrict the level of UK emissions across five-year periods; see Table 12. The first and second budget were successfully met. Whilst the UK is on target to outperform the third budget, it is not set to meet the fourth without greater decarbonisation efforts [179]. In December 2020, the CCC are expected to publish a recommendation on the level of the sixth carbon budget [180].

\begin{tabular}{cccc}
\hline Budget Number & Time Period & $\begin{array}{c}\text { Carbon Budget } \\
\text { Allowance }\left(\mathbf{M t C O}_{\mathbf{2}} \mathbf{e}\right)\end{array}$ & $\begin{array}{c}\text { Reduction Compared } \\
\text { to 1990 Levels (\%) }\end{array}$ \\
\hline 1 & $2008-2012$ & 3,018 & 25 \\
2 & $2013-2017$ & 2,782 & 31 \\
3 & $2018-2022$ & 2,544 & 37 by 2020 \\
4 & $2023-2027$ & 1,950 & 51 by 2025 \\
5 & $2028-2032$ & 1,725 & 57 by 2030 \\
\hline \hline
\end{tabular}

Table 12 - UK Carbon Budgets. Data Retrieved from [179].

\subsection{Carbon Pricing}

Carbon pricing is an important policy consideration for conventional hydrogen production processes because of their high carbon intensity [181]. There are two ways in which this may be implemented. One approach is carbon taxing where a fee is paid per unit of emissions. Another is a cap-and-trade 
system where industries purchase credits in order to emit [182]. Some advantages of carbon pricing include:

1. It is technology neutral which allows emitters to find the lowest-cost way to reduce emissions

2. It allows regulators to cost-effectively limit GHG emissions without the need to develop expertise in manufacturing processes

3. It generates government revenue which can be utilised to support investment in R\&D initiatives [183].

\subsubsection{EU-Emission Trading System (ETS)}

The EU-ETS operates on the cap-and-trade principle. In this system, emission levels are capped, and companies can buy or receive emission allowances, which can be traded as required. If allowances are not sufficient to cover emissions at the end of the year, heavy fines are imposed [184]. A wellfunctioning trading system will increase the cost of carbon-intensive hydrogen production processes which could make CCS more cost competitive [181]. Until $31^{\text {st }}$ December 2020, the UK will remain a full participant of the EU-ETS. Following this, a future carbon pricing system will be developed [185].

\subsection{Government Strategy Papers and Other Publications}

UK government has outlined its commitment to decarbonisation through various strategy papers, grand challenges and publications. This sub-section highlights those which recognise hydrogen technologies and their potential.

\subsubsection{Industrial Strategy}

In 2017, HM Government released the 'Industrial Strategy' white paper, which provided a structured approach to promote the transformation of the economy. The following four 'Grand Challenges' were identified as key research focus areas to enable this transformation: artificial intelligence and data revolution, the shift to clean growth, the future of mobility and an ageing society [186].

\subsubsection{Clean Growth Strategy}

The Clean Growth Strategy paper was published shortly after the Industrial Strategy. Clean growth is conceptualised as "growing national income while cutting greenhouse gas emissions" [187]. Challenges identified in this report included decarbonisation of the transport sector, reducing emissions from the domestic and business sector and making CCUS a viable future option. In the hydrogen pathway proposed, hydrogen production reached 750TWh by 2050 to achieve emission targets. All cars and vans were powered by hydrogen and most buildings utilised a hydrogen grid. Complementary low-carbon technologies such as renewable electricity, district heating and CCUS also had a role in this scenario [187].

\subsubsection{Delivering Clean Growth}

The CCUS Cost Challenge Taskforce was established by UK government to provide recommen dations on how the cost of CCUS could be lowered [188]. In their report, Delivering Clean Growth, the taskforce urged that value could be unlocked through enabling a hydrogen economy by implementing CCUS technologies [189].

\subsubsection{UK Government Response: CCUS Deployment Pathway}


In response, UK government published an action plan designed to enable the deployment of the first CCUS facility in the UK, commissioning from the mid-2020s in order to allow the deployment of CCUS at scale by 2030 [190]. It was highlighted that this could contribute to the development of evidence to support decisions on the potential large-scale use of hydrogen.

\subsubsection{Industrial Clusters Mission}

In 2018, UK government announced the Industrial Clusters mission as part of the wider Clean Growth challenge and Industrial Strategy. The aim of this is to establish one net-zero carbon industrial cluster by 2040 and at-least one low-carbon cluster by 2030 [191]. Hydrogen is recognised as having a role in this challenge.

\subsubsection{Other Strategy Documents}

By quarter one of 2020, government were expected to release an Energy White Paper to outline the UK's strategy for achieving net-zero emissions as well as the role of nuclear energy [192]. Because of COVID-19 it is unknown when this document will now be published.

In July 2020, the European Commission published an EU hydrogen strategy outlining how demand for hydrogen can be driven across a range of sectors [193]. As well as the much anticipated Energy White Paper, key stakeholders are also calling for a UK-wide hydrogen strategy to unlock significant investment in hydrogen technologies across the country [194].

\subsection{Investment in Research \& Development (R\&D)}

Because hydrogen technologies are more costly than fossil-fuel alternatives, support in R\&D is required, which can lead to cost decreases due to the accumulation of experience [195]. Investment in R\&D can also help speed technological development [182]. This is crucial given the time limits imposed by emission targets.

\subsubsection{Funding Streams to Support Hydrogen}

In early 2020, UK government announced a $f 90 \mathrm{~m}$ package, as part of the BEIS $f 500 \mathrm{~m}$ innovation fund, dedicated to rolling out low-carbon technology. Hydrogen production projects were allocated $\mathrm{f} 28 \mathrm{~m}$ through the Hydrogen Supply competition. A list of these projects and the amount of funding allocated is shown in Table 13. Please note that hydrogen projects other than those focused on production have also been funded through alternative funding streams such as the Industrial Fuel Switching Programme.

\begin{tabular}{cc}
\hline Project & Funding Allocated $(\mathbf{f m})$ \\
\hline Dolpyhn Project & 3.12 \\
HyNet & 7.48 \\
Gigastack & 7.50 \\
Acorn & 2.70 \\
HyPER & 7.44 \\
\hline
\end{tabular}

Table 13 - Funding Received for Successful Hydrogen Projects in Phase 2 Hydrogen Supply Competition [196].

\subsubsection{Industrial Decarbonisation Challenge (IDC)}

The Industrial Decarbonisation Challenge is a $₫ 170 \mathrm{~m}$ pot funded through the Industrial Strategy Challenge Fund. This challenge aims to enable the deployment of low-carbon technology, at scale, by the mid-2020s and will support the delivery of the Clean Growth Challenge and Industrial Clusters mission [197]. In April 2020, the winners of the phase 1 deployment and roadmap competitions were announced [198]. Further information can be found in Section 7. 


\subsubsection{Hydrogen Projects Funded through OFGEM}

OFGEM is an official government body and Independent National Regulatory Authority, which protects the interests of existing and future electricity and gas consumers. OFGEM provides funding for low-carbon initiatives across the gas and electricity networks. Two examples of funding streams are the Gas Network Innovation Competition (NIC) and Gas Network Innovation Allowance (NIA) [199].

In 2019, the gas NIC was awarded to Northern Gas Networks for their H21 Phase 2 project. This project seeks to provide quantified safety-based evidence to confirm whether GB gas networks are suitable for $100 \%$ hydrogen. This will be achieved through an appraisal of procedures, modelling and testing [200]. For the 2020 NIC award, two projects have been chosen to proceed to the 'Full Submission' stage. One of these projects is H100 Fife (SGN) which aims to construct an end-to-end distribution network to test hydrogen. The other is HyNTS (National Grid Gas) which aims to test transmission network assets with hydrogen blends between $20-100 \%$, at transmission pressure [201]. Project HyDeploy has also received $f 6.7 \mathrm{~m}$ under the gas NIC [158]. This is a ten month demonstration project, at a private gas network at Keele University, to determine the level of hydrogen which can be used by customers safely [202].

\subsubsection{UK Budget: 2020}

In the 2020 Budget, HM Treasury recognised the importance of hydrogen in securely supplying lowcarbon power as well as its potential in decarbonising industry [203]. Whilst there was no specific mention of a hydrogen fund in the budget, a new CCS Infrastructure Fund, of $£ 800 \mathrm{~m}$, was announced. This funding will be utilised to establish CCS in at least two UK sites; one by mid-2020s and a second by 2030. This could complement the deployment of hydrogen technologies [189].

\subsection{Green Subsidies}

Subsidies can be delivered through various mechanisms to provide financial support for low-carbon hydrogen. Examples include grants, low-interest loans and tax exemptions [204]. As hydrogen is more expensive than conventional fuels, this will inevitably bear a greater cost to the consumer. Meaning, subsidies will initially be required to allow hydrogen to compete with the cost of alternative fuels.

Tax exemptions for hydrogen fuel are present in the transport sector. Hydrogen utilised in HFC vehicles are exempt from fuel duty. Furthermore, because they are classed as zero-emission vehicles, they are exempt from paying vehicle excise duty [205]. Other than this, there are a lack of subsidies which support hydrogen production and its end-use consumption. This differs considerably to the likes of renewable electricity which has received many subsidies over recent years. Examples include the Renewable Obligation (RO), Feed-in-Tariffs (FIT), Contracts for Difference (CfD), and the Renewable Heat Incentive (RHI). Further information on these programmes can be located at the following source: [206].

\subsection{Policy Recommendations}

Despite the current policy measures in place to support hydrogen in the UK, there are still many shortcomings which must be addressed before a hydrogen economy can be established $[24,207]$. Some general policy recommendations, for government, found in the literature are as follows:

1. Develop a cross-departmental hydrogen strategy in government [202] 
2. Provide more resources and greater powers for local authorities in decarbonisation strategy plans [192]

3. Significantly ramp up policy measures to make net-zero targets credible, particularly for heat and aviation [15]

4. Seek views on possible market and commercial structures, financing options and funding sources for hydrogen [207]

5. Address investment risks of first-movers in hydrogen technologies [11]

For specific policy recommendations concerning individual elements of a hydrogen system see Table 14.

\begin{tabular}{|c|c|c|c|c|}
\hline $\begin{array}{l}\text { Hydrogen } \\
\text { Production }\end{array}$ & $\begin{array}{l}\text { Hydrogen } \\
\text { Transport and } \\
\text { Distribution }\end{array}$ & Domestic Sector & Transport Sector & Industrial Sector \\
\hline $\begin{array}{l}\text {. Provide Financial } \\
\text { support for hydrogen } \\
\text { generation } \\
\text {. Decrease distortive } \\
\text { incentives by } \\
\text { increasing VAT on } \\
\text { carbon intensive fuels } \\
\text {. Drive down costs and } \\
\text { increase } \\
\text { competiveness by } \\
\text { prioritising } \\
\text { demonstration } \\
\text { projects }\end{array}$ & $\begin{array}{l}\text {. Provide financial } \\
\text { support for blending } \\
\text { hydrogen into gas } \\
\text { grid } \\
\text {. Encourage green } \\
\text { gas by changing the } \\
\text { GSMR to } \\
\text { accommodate } \\
\text { hydrogen injection }\end{array}$ & $\begin{array}{l}\text {. Improve supply } \\
\text { chains so that } \\
\text { warranties and } \\
\text { appliances allow for } \\
\text { hydrogen } \\
\text { Provide appropriate } \\
\text { governance in the } \\
\text { socialisation of costs }\end{array}$ & $\begin{array}{c}\text { Collaborate to } \\
\text { establish } 100 \text { HRS by } \\
2025 \\
\text {. Financial support } \\
\text { for hydrogen in the } \\
\text { transport sector } \\
\text {. Develop a HRS } \\
\text { network for haulage } \\
\text { vehicles } \\
\text { Allow hydrogen } \\
\text { transport pilots }\end{array}$ & $\begin{array}{l}\text {. Provide financial } \\
\text { support for industry } \\
\text {. Develop industrial } \\
\text { hydrogen hubs } \\
\text {. Promote fuel } \\
\text { switching options } \\
\text { and identify how } \\
\text { costs can be lowered } \\
\text {. Complement } \\
\text { industrial clusters } \\
\text { funding with market } \\
\text { creation policies }\end{array}$ \\
\hline
\end{tabular}

Table 14 - Policy Recommendations for Specific Applications of Hydrogen. Retrieved from [24, 192, 202].

\section{Regulatory Considerations}

To best develop regulations, codes and standards for any particular technology, lengthy consultations between regulators, industry and academics are required. Sufficient regulatory frameworks for hydrogen technologies are still lacking across many countries and are still far from being harmonised [208]. Hydrogen displays various unique characteristics which inhibit the extrapolation of existing standards from conventional fuels. These include its requirements for storage at high pressure and extremely low temperatures, distinctive thermodynamic properties, high purity requirement for fuel-cell applications and difficulty in detection [209]. Such characteristics have various regulatory implications.

\subsection{Hydrogen Production}

At a centralised scale, there are no legal and administrative concerns or recommendations for regulatory amendments for hydrogen production processes. At a local level, where production is most likely to be electrolyser based, the regulatory procedures are aligned with centralised production with no simplified process for low volume production [210]. Typical examples of legislation required for hydrogen production infrastructure include Environmental Impact Assessments (EIA), the Town and Country Planning Act, the Hazardous Substances Act and COMAH (2015) Regulations [211].

\subsubsection{Hydrogen Business Models: Could they be Regulated?}


One of the most difficult non-legislative challenges faced for hydrogen production is the uncertainty around business models. There are numerous options for the operation and ownership of hydrogen infrastructure assets. They could be built, owned and financed by the private sector without commercial regulation. Or, they could operate in regulated markets through the likes of the Regulated Asset Base (RAB) model [207]. This would involve treating hydrogen as a national utility with an appropriate allocation of risk in order to reduce the cost of capital. Ultimately, this could lower the level of support required to deliver commercial projects [212].

In a recent report commissioned by the Department for Business, Energy \& Industrial Strategy (BEIS), Frontier Economics identified four business model categories that could potentially provide an incentive for investment in low-carbon hydrogen production: Contractual payments to producers, regulated returns, obligations and end user subsidies [213]. Whilst this report is a step in the right direction, it focuses mainly on the supply of hydrogen to industry as well as near term investments. Due to the large decarbonisation potential of hydrogen across various sectors, further research will be required concerning the suitability of business models for alternative applications of hydrogen. In a recent publication, UK government highlighted that they would continue to work closely with industry to assess viable hydrogen business models [214].

In other sectors innovative decisions have been made to increase competition for projects and jumpstart investment into capital assets. For example, the offshore transmission regime (OFTO) opened a market for transmission assets in the UK offshore wind market. Subsequently, this attracted new investors and created a secondary market. For further information, please refer to the following source: [215].

\subsection{Transport and Distribution}

Hydrogen transportation and distribution appears to have the most regulatory restrictions at present. Without legislation that supports hydrogen within gas networks, demonstration projects could be bottle-necked [216].

\subsubsection{Gas Control of Thermal Energy Regulations (CoTER)}

Under the COTER, customers are charged based on the average calorific value of gas across thirteen zones in the UK. In order to match the calorific value of gas across an entire zone, enriching or deriching processes are required [217]. Because the thermodynamic properties of hydrogen differ to natural gas, this could potentially prohibit small-scale demonstration projects in individual locations. Any changes made to accommodate unconventional gases within this legislation must ensure customers are not disadvantaged through unfair billing [218]. To address this issue, Cadent have developed the future billing methodology project. This project seeks to create a way to measure the blend of gases and explore fair options for billing which are fit-for-purpose in a lower-carbon future. One potential option is to assign specified calorific values at a more local level to avoid the need for additional gas processing $[219,220]$.

\subsubsection{Gas Safety (Management) Regulations (GS(M)R)}

The GS(M)R (1996) stipulates that hydrogen content in natural gas supplied to domestic homes should be no greater than $0.1 \%$ molar volume [221], despite the fact that 'town gas' was distributed with approximately $50 \%$ hydrogen content until the 1970 s [222]. This is consistent with other countries like Italy. However, countries like France and Denmark, have more supportive legislations where permittable concentrations range from up to 6-10\% [223]. Existing Wobbe Index limits under the GS(M)R also influence permittable hydrogen content as hydrogen blends will lower this value; 
see Section 2.2.1. The current restraints of the GS(M)R mean that pilot demonstration projects can only be undertaken on smaller isolated networks. It is recommended that amendments to the GS(M)R should be brought forward as a matter of urgency, to enable the large-scale demonstration of hydrogen injection into the gas grid [224]. UK government have confirmed that this is under review by the Health and Safety Executive (HSE) who have the authority to grant exemptions [218]. An exemption has already been granted to the HyDeploy project [158].

\subsubsection{RIIO-2}

Ofgem are responsible for overseeing the second period of price controls for network companies across the gas and electricity transmission and distribution networks. This is referred to as RIIO-2 (Revenue $=$ Incentives + Innovation + Outputs). The new price control period for UK gas networks will run between 2021 and 2026 [225]. It is therefore important that the allowable spend on hydrogen throughout this period is clearly defined [24].

In 2019, gas network operators submitted their business plan for this period which included considerations and visions for hydrogen in the gas network. In response, the RIIO-2 Challenge Group highlighted the following conclusions concerning hydrogen:

- The workforce is not necessarily prepared for a hydrogen future and more Chartered engineers will be required

- The ability of the steel Local Transmission System to accommodate hydrogen transmission is not clear ${ }^{5}$

- It appears that hydrogen leaks may not be any more significant than gas in terms of safety of the public

- There is little discussion on the extent that assets are compatible with $100 \%$ hydrogen $^{6}$ [226].

At the end of 2020, Ofgem are expected to publish their final view on the price control allowances [225].

\subsubsection{Appliances}

It is important to note that all appliances sold after 1993, must comply with the 1990 Gas Appliance Directive (GAD) 90/396/CCE, which demonstrates that they can operate on a wider range of gas quality than specified in the GS(M)R and specifies a gas composition of $23 \%$ hydrogen [227]. Although not all appliances in the UK are post 1993 and the GAD does not consider long-term operation, this legislation could be supportive for hydrogen use in the home.

\subsection{Hydrogen Refuelling Stations (HRS)}

In recent years, support for HRSs has increased in the UK with best practice guides for installation now available [228]. Despite this, there are still regulatory challenges to be addressed concerning quality assurance, flow metering, quality control and sampling. Further information concerning existing codes, standards and regulations and further recommendations for improvement can be found at the following sources: [208, 229, 230].

\subsection{Overview of Severity of Legal Barriers for Various Hydrogen Applications}

\footnotetext{
${ }^{5}$ Comment made in response to Cadent's business plan.

${ }^{6}$ Comment made in response to National Grid Gas Transmission's business plan.
} 
The HyLaw project aimed to provide a clear view of applicable regulations and draw attention to legal barriers concerning numerous hydrogen technologies and applications. Using conclusions from this project,

Table 15 highlights the severity of legal barriers faced across various hydrogen applications in the UK in comparison to the European average. In the UK and across Europe, gas grid issues have the highest severity [223]. Further information concerning this project, and the data retrieved, can be found at the following source: [231].

\begin{tabular}{ccc}
\hline Application of Hydrogen & $\begin{array}{c}\text { Average Severity of Barriers for } \\
\text { Hydrogen Application for UK }\end{array}$ & $\begin{array}{c}\text { Average Severity of } \\
\text { Barriers for Hydrogen } \\
\text { Application for Europe }\end{array}$ \\
\hline $\begin{array}{c}\text { Hydrogen Production } \\
\text { Hydrogen Storage }\end{array}$ & 1.7 & 1.2 \\
Transport and Distribution of & 2.0 & 1.2 \\
Hydrogen & 0.7 & 0.5 \\
Hydrogen as a Fuel & 1.0 & 1.2 \\
Vehicles & 1.8 & 1.2 \\
Electricity Grid Issues & 1.0 & 1.3 \\
Gas Grid Issues & 3.0 & 2.2 \\
Stationary Power & 1.3 & 1.9 \\
\hline Values shown in column 3 were calculated using Web Plot Digitizer as these were not quantified in the \\
bar chart from the original source: [223] (Fig2, p.7).
\end{tabular}

Table 15 - Average Severity of Legal and Administrative Processes for Various Applications of Hydrogen. Where: 0 is the lowest severity and 3 is greatest. Data Retrieved from the HyLaw project [211, 223].

\section{Social Considerations}

Public perception remains a critical consideration in the deployment of new technologies and has been shown to either encourage or slow down innovation [232]. In previous low-carbon projects, it has been a positive factor behind successful operation [233]. This is therefore pivotal to the establishment of both local and national hydrogen networks. This section highlights research which has focused on the acceptance of hydrogen. Please note that some studies were not conducted in the UK and where this is the case, it is indicated. Whilst conclusions drawn from these studies may not be directly translatable to a UK context, they provide insight and learning opportunities.

\subsection{Acceptance of Hydrogen}

Previous studies indicate that people have positive beliefs and attitudes towards hydrogen and accept its development as a fuel [234]. For example, in a recent UK study, $50 \%$ of participants supported the conversion of home heating to hydrogen [235]. At this stage of diffusion to a hydrogen economy, attitudes can change rather easily by providing short and neutral information. However, this also means that the strength and stability of positive attitudes is rather low [236]. This section covers various factors which have an influence on the acceptance of hydrogen technologies.

\subsubsection{Awareness of Hydrogen}

An increased knowledge and understanding can lead to greater support for hydrogen but can also lead to greater opposition and indifference [237]. This makes it an important factor for consideration. 
In Spain, one study observed high-levels of awareness concerning the existence of hydrogen as a transportation fuel [238]. This differs from findings of other studies. For example, one study in America indicated that only $35 \%$ of a total sample were able to correctly answer eight questions about hydrogen technologies. Furthermore, almost 9 out of 10 individuals considered themselves 'not familiar' or 'slightly familiar' with hydrogen and fuel cell technologies [239]. Another study in Japan, in 2008, explored participants awareness of hydrogen. Only $32 \%$ claimed that they knew about hydrogen, which was lower than results observed for alternative forms of energy such as solar, nuclear and wind [240]. However, when asked again in 2015, this value increased by $12 \%$. Generally, the literature shows low levels of hydrogen awareness as well as low numbers of participants who are able to answer technical questions concerning hydrogen [234].

\subsubsection{Information Sharing}

To aid in stabilising the acceptance of hydrogen, further information campaigns or projects to familiarise people with hydrogen technologies will be necessary. As long as individuals are indifferent, they can be informed and convinced about hydrogen technologies more easily [241].

As part of the HyDeploy initiative, one study found that considerably more people would be willing to use hydrogen in their homes after being giving two further pieces of information. The first was confirmation that their home appliances had been tested and deemed suitable for usage. Secondly, they were informed that town gas, supplied to homes in the past, had a high hydrogen content [242]. Another study in Japan showed higher acceptance for HRSs being built near the home once risk and safety information had been shared. This was likely because issues concerning uncertainty were addressed [243]. On the other hand, this study observed a lower acceptance for HRSs being built near a local gas station as this left participants feeling anxious after risk and safety information was shared.

\subsubsection{Willingness to Pay}

Several studies have assessed whether individuals are willing to pay for hydrogen. Mixed conclusions have been drawn depending on the context in which surveys were executed as well as the methodology utilised [234].

In one study in the UK, when asked about their willingness to pay for hydrogen fuel for domestic applications, over $60 \%$ of participants highlighted that they could not pay, even if they wished to, due to low wages and ever increasing energy bills [242]. Furthermore, several participants displayed sensitivity toward the possible distributional injustice of hydrogen costs. As mentioned, this is an issue addressed in the future billing methodology project [219]. Another UK study, as part of the H21 initiative, supports these findings. This study identified that participants were concerned about the higher cost of hydrogen and the need to purchase new appliances [244].

Regarding the purchase of hydrogen vehicles in the transport sector, a Spanish study identified operation and maintenance costs of HFC vehicles as key barriers [238].

A study conducted in Greater Stavanger identified that younger individuals were more likely to indicate a willingness to pay than older individuals. This is likely because younger individuals have greater access to information about the negative consequences of using conventional, carbon intensive fuels [237].

\subsubsection{Overview of Other Influential Factors of Hydrogen Acceptance}


This sub-section provides an overview of additional factors which can positively or negatively influence the acceptance of hydrogen. Key findings from the literature are shown in Table 16. As well as those identified in Table 16, the underground storage of hydrogen and hydrogen pipelines are factors which could also influence public acceptance. In a German study, the following statements were given to participants: "I would have no concern if hydrogen were stored underground like natural gas" and "Additional gas pipelines for the hydrogen transport would be a good solution" [245]. Respectively, $37.4 \%$ and $40.4 \%$ of participants disagreed with these statements. In comparison to other statements concerning the recognition of hydrogen for energy supply and climate protection, this level of disagreement was considerable.

\begin{tabular}{|c|c|c|c|}
\hline \multicolumn{2}{|c|}{ Positive Factors } & \multicolumn{2}{|r|}{ Negative Factors } \\
\hline $\begin{array}{l}\text { Environmental } \\
\text { Impact }\end{array}$ & $\begin{array}{l}\text {. Hydrogen has a favourable public } \\
\text { perception in terms of } \\
\text { environmental performance and } \\
\text { sustainability [238]. }\end{array}$ & Economic Issues & $\begin{array}{l}\text { Costs of hydrogen vehicles is a key } \\
\text { barrier in hindering the success of } \\
\text { hydrogen vehicles [238]. }\end{array}$ \\
\hline $\begin{array}{l}\text { Ability to Meet } \\
\text { Modern Heating } \\
\text { Demands \& } \\
\text { Existing Practices }\end{array}$ & $\begin{array}{l}\text {. Hydrogen is perceived as progress } \\
\text { to a more modern version of } \\
\text { natural gas, where the progression } \\
\text { views for heat pumps were less } \\
\text { clear [246]. } \\
\text {. Hydrogen is seen to be more of a } \\
\text { like-for-like replacement of the } \\
\text { current natural gas system and } \\
\text { easier to grasp than alternative } \\
\text { technologies such as heat-pumps } \\
\text { [246]. }\end{array}$ & Technical Issues & $\begin{array}{l}\text { Technical issues such as availability } \\
\text { of refuelling stations and vehicle } \\
\text { features is a key barrier in hindering } \\
\text { the success of hydrogen vehicles } \\
\text { [238]. }\end{array}$ \\
\hline $\begin{array}{l}\text { Economic } \\
\text { Opportunities }\end{array}$ & $\begin{array}{l}\text { Hydrogen technologies are } \\
\text { perceived as providing the } \\
\text { opportunity to create jobs and } \\
\text { provide services as well as allowing } \\
\text { companies to grow their } \\
\text { businesses [247]. }\end{array}$ & $\begin{array}{l}\text { Installation } \\
\text { Burden for } \\
\text { Hydrogen in } \\
\text { Homes }\end{array}$ & $\begin{array}{l}\text { The main barrier to acceptability } \\
\text { for hydrogen for heating is the one } \\
\text { to two weeks disconnection from } \\
\text { gas supply during installation } \\
\text { periods [246]. } \\
\text { The need to replace all gas } \\
\text { appliances is also perceived as a } \\
\text { barrier to hydrogen for heating } \\
\text { applications [246]. }\end{array}$ \\
\hline $\begin{array}{l}\text { Ability to Address } \\
\text { Current Energy } \\
\text { System Flaws }\end{array}$ & $\begin{array}{l}\text { Raising awareness of problems } \\
\text { with the current energy system } \\
\text { influences the general acceptance } \\
\text { of hydrogen technologies [248]. }\end{array}$ & $\begin{array}{c}\text { Familiarity of } \\
\text { Experience }\end{array}$ & $\begin{array}{l}\text {. Invisibility of hydrogen flame } \\
\text { imagined by participants as being } \\
\text { particularly disruptive to their } \\
\text { practices of cooking [249]. } \\
\text { Therefore, suitable colourants are } \\
\text { imperative to acceptance. }\end{array}$ \\
\hline & & $\begin{array}{l}\text { Large Scale } \\
\text { Development and } \\
\text { Infrastructure }\end{array}$ & $\begin{array}{l}\text { Support for hydrogen applications } \\
\text { and infrastructure is less } \\
\text { enthusiastic in comparison to } \\
\text { general acceptance of hydrogen } \\
\text { [245]. } \\
\text {. Hydrogen technologies may be } \\
\text { perceived as being sustainable but } \\
\text { still a disruption to the local } \\
\text { environment [248]. }\end{array}$ \\
\hline
\end{tabular}

Table 16 - Overview of positive and negative factors which could influence the public acceptance of hydrogen found throughout the literature.

\section{Status of On-Going Hydrogen Projects and Initiatives}

7.1 Large Scale Integrated Projects (LSIPs) 
LSIPs are defined as projects which involve the capture, transportation and storage of $\mathrm{CO}_{2}$ at rates of 400,000-800,000t per annum dependent on the industrial facility [250]. As mentioned, fossil-fuel based hydrogen production requires additional carbon mitigation technologies, like CCS, to avoid an overall net-increase of $\mathrm{CO}_{2}$ emissions [24]. To align with the scope of this article, only LSIPs which incorporate hydrogen production and CCS will be discussed. Reference will be given to those already operational as well as those proposed in various industrial cluster initiatives.

\subsubsection{Global Overview of Large-Scale Hydrogen Production with CCS}

Across the globe, there are few operational hydrogen plants which incorporate CCS technologies; see Table 17. Traditionally, these plants have utilised $\mathrm{CO}_{2}$ for enhanced oil recovery (EOR). However, in more recent projects, like Quest, $\mathrm{CO}_{2}$ has been captured and permanently sequestered for decarbonisation purposes.

\begin{tabular}{|c|c|c|c|c|c|c|}
\hline Project & Location & Industry & $\begin{array}{c}\text { Year of } \\
\text { Operation }\end{array}$ & $\begin{array}{l}\text { Hydrogen } \\
\text { Production } \\
\text { Technology }\end{array}$ & $\begin{array}{c}\text { Hydrogen } \\
\text { Production } \\
\text { Rate } \\
\text { (t/d) }\end{array}$ & $\begin{array}{c}\mathrm{CO}_{2} \\
\text { Capture } \\
\text { Rate } \\
(\mathrm{Mt} / \mathrm{y})\end{array}$ \\
\hline Great Plains & $\begin{array}{l}\text { Beulah, } \\
\text { North } \\
\text { Dakota }\end{array}$ & Synfuels & 2000 & $\begin{array}{c}\text { Coal } \\
\text { Gasification }\end{array}$ & 1300 & 3 \\
\hline Air Products & $\begin{array}{c}\text { Port Arthur, } \\
\text { Texas }\end{array}$ & $\begin{array}{l}\text { Hydrogen } \\
\text { Production }\end{array}$ & 2013 & SMR & 500 & 1 \\
\hline Quest & $\begin{array}{l}\text { Alberta, } \\
\text { Canada }\end{array}$ & $\begin{array}{l}\text { Hydrogen } \\
\text { Production }\end{array}$ & 2015 & SMR & 900 & 1 \\
\hline CoffeyVille & $\begin{array}{c}\text { CoffeyVille, } \\
\text { Kansas }\end{array}$ & Fertiliser & 2013 & Gasification & 200 & 1 \\
\hline $\begin{array}{c}\text { ACTL } \\
\text { Sturgeon }\end{array}$ & $\begin{array}{l}\text { Alberta, } \\
\text { Canada }\end{array}$ & $\begin{array}{l}\text { Refinery and } \\
\text { Fertiliser }\end{array}$ & 2020 & $\begin{array}{c}\text { Gasification } \\
\text { and } \\
\text { Reforming }\end{array}$ & $\begin{array}{l}>240 \text { and } \\
>800\end{array}$ & $1.2-1.4$ \\
\hline Porthos & $\begin{array}{l}\text { Rotterdam, } \\
\text { Netherlands }\end{array}$ & $\begin{array}{c}\text { Refinery and } \\
\text { Hydrogen } \\
\text { Production }\end{array}$ & 2023 & $\begin{array}{l}\text { SMR } \\
\text { ATR }\end{array}$ & - & $2-5$ \\
\hline CarbonNet & $\begin{array}{l}\text { Victoria, } \\
\text { Australia } \\
\end{array}$ & - & $2025+$ & - & - & $2-5$ \\
\hline
\end{tabular}

\subsubsection{Industrial Clusters}

Industrial clusters present great opportunity for hydrogen networks as they're commonly situated near existing oil and gas facilities and potential $\mathrm{CO}_{2}$ storage sites. Because of the close proximity of multiple industrial sites, transmission and distribution infrastructure costs are also lower [11]. One example is the Port of Rotterdam which is recognised as the most advanced cluster proposal in mainland Europe [261]. The cluster is evolving to a carbon neutral economy in a three-step transition which integrates hydrogen production, CCS and many other low-carbon technologies [262]. Proposals for low-carbon hydrogen production in the cluster include: PORTHOS [255], HVISION [259], H2.50 as well as a 200MW green hydrogen plant [263].

In the UK, the six largest industrial clusters emit approximately 40 million tonnes of $\mathrm{CO}_{2}$ per year, which equates to approximately one third of all business and industrial emissions [197]. For each 
cluster, a brief summary of large-scale decarbonisation initiatives is given, where the significance of hydrogen varies throughout. Please note this is not an exhaustive review of each cluster and further information can be found at the sources referenced.

\subsubsection{Teesside}

In 2018, the Clean Gas Project was launched by the Oil and Gas Climate Initiative (OGCI). This project entailed power generation from natural gas, with $\mathrm{CO}_{2}$ captured and transported, via pipeline, for storage in the Southern North Sea [264]. The project sought to store $6 \mathrm{Mt} \mathrm{CO}_{2}$ per year in storage sites with an excess of $1000 \mathrm{Mt}$ storage capacity [265]. Since then, the project has expanded to include a transportation and storage system to collect $\mathrm{CO}_{2}$ from other industries in the region including fertiliser and hydrogen plants [266]. The project is now titled Net Zero Teesside [267]. In 2019, an application for a scoping opinion was submitted to the Planning Inspectorate with a development consent application expected in the fourth quarter of 2020 [268]. No sources could be found which indicate plans for additional hydrogen production facilities in the region.

\subsection{Humberside}

The Humber is the most carbon intensive cluster in the UK and emits $14 \mathrm{MtCO}_{2}$ each year [269]. In 2019, Drax Group, Equinor and National Grid signed a Memorandum of Understanding (MoU), committing them to work together to explore the opportunities for a zero-carbon cluster in the Humber [270]. This is split into two phases. In the first, critical infrastructure will be installed including carbon capture on one of the four Drax biomass units to enable BECCS by 2027, an ATR for hydrogen production by 2025 and the development of $\mathrm{CO}_{2}$ transport and storage infrastructure for storage in the Southern North Sea [271]. Key proposals for phase 2 are as follows:

- $\quad$ BECCS capacity of $16 \mathrm{MtCO}_{2}$ per year

- Hydrogen production capacity of $13.7 \mathrm{GW}$ by 2050

- $13 \mathrm{MtCO}_{2}$ per year captured from industry and power stations within the region

This project will align with the $\mathrm{H} 21$ project. More details about this can be found at the following source: [102].

\subsection{North West}

The HyNet project envisions hydrogen production with integrated CCS infrastructure. Produced hydrogen will be supplied to end users via a newly constructed pipeline that permits up to $1.5 \mathrm{GWh}$ of hydrogen storage through line packing. The initial end uses of hydrogen are injection into the local gas transmission system for blending and fuel switching for industrial users. The captured $\mathrm{CO}_{2}$ from the hydrogen production plant, as well as that from industrial emitters, will be transported, via pipeline, to the Liverpool Bay gas fields for long term storage. This will have an initial capacity of $10 \mathrm{Mt} \mathrm{CO} 2$ per year [272]. In the short term, an LCH plant with a production rate of $100 \mathrm{kNm}^{3} / \mathrm{hr}$ will be built on Essar's Stanlow Refinery, which will supply approximately 3000GWh per year of hydrogen. The Front-End Engineering Design (FEED) will be completed by March 2021 and the plant could be operational in mid-2024 [273]. CCS infrastructure is expected to follow a similar timeframe.

\subsection{Grangemouth}

Project Acorn obtained the first UK $\mathrm{CO}_{2}$ appraisal and storage license from the Oil and Gas Authority and has the potential to be operating in 2023. This project consists of two elements: CCS and hydrogen production [274]. A repurposed pipeline will be utilised to transport industrial $\mathrm{CO}_{2}$ emissions from the Grangemouth cluster to an injection site, at St. Fergus, for offshore storage. 
Storage rates of $2 \mathrm{Mt}$ per year are expected [275]. A 200MW LCH production plant is planned at St. Fergus for direct blending, at 2\% volume, into the National Transmission System [275]. At present, Acorn CCS is in the detailed engineering phase. The final investment decision (FID) is expected in late 2021 [274].

\subsection{Southampton}

In comparison to other clusters, the literature concerning decarbonisation initiatives in Southampton is minimal. Whilst no large-scale decarbonisation plans could be found, the following sources highlighted the lack of direct storage sites for $\mathrm{CO}_{2}$ in the region: $[276,277]$. This means that additional compression and liquefaction infrastructure would be required for $\mathrm{CO}_{2}$ transportation to alternative storage sites, which could cause CCS operations to commence later than other clusters. No sources concerning hydrogen activity in the region were found.

\subsection{South Wales}

South Wales faces problems similar to that of Southampton with regard to offshore storage facilities for $\mathrm{CO}_{2}$ [276]. The cluster is still in the early phases of developing a large-scale plan for decarbonisation. Despite this, there are several initiatives in the region which are exploring lowcarbon technologies. ZERO2050 is an initiative led by National Grid which aims to speed up the rate of progress in meeting government targets [278]. The FLEXIS operation focuses on developing flexible energy systems and all research will focus on and be applied at a demonstrator in Tata Steel, Port Talbot. Hydrogen focused work packages within this research programme are as follows [279]:

- WP5: Hydrogen Energy Storage

- WP6: Sustainable Production and Purification of Hydrogen, Syngas, Bio-hydrogen and Biomethane

- WP7: Hydrogen and Syngas: Efficient Use

- WP15: Energy Vectoring through Hydrogen

\subsubsection{The Industrial Decarbonisation Challenge}

The decarbonisation of UK industrial clusters is recognised as a key challenge. The IDC aims to accelerate cost-effective decarbonisation of industry as well as enabling the deployment of infrastructure at scale by the mid-2020s [197]. It is envisioned that CCUS, hydrogen, bioenergy and clean electricity will be vital technologies in these decarbonisation efforts [191].

\subsection{Phase 1 Winners}

In April 2020, the winners for the first phase of the deployment and roadmaps competitions, as part of the wider IDC, were announced. These are summarised in Table 18. For further information please see the following source: [198].

\begin{tabular}{cc|cc}
\hline \multicolumn{2}{c|}{ Phase 1: Deployment Competition Winners } & \multicolumn{2}{|c}{ Phase 1: Roadmap Competition Winners } \\
\hline Name of Project & Region & Name of Project & Region \\
\hline $\begin{array}{c}\text { Scotland's Net Zero } \\
\text { Infrastructure }\end{array}$ & $\begin{array}{l}\text { Net Zero Tees Valley - } \\
\text { Decarbonising the Full } \\
\text { Cluster: Roadmap } \\
\text { Pathfinder } \\
\text { Net Zero Teesside } \\
\text { Project }\end{array}$ & $\begin{array}{c}\text { Scotland's Net Zero } \\
\text { Roadmap (SNZR) }\end{array}$ & Tees valley \\
& Teesside & Scotland
\end{tabular}




\begin{tabular}{|c|c|c|c|}
\hline $\begin{array}{l}\text { Humber Industrial } \\
\text { Decarbonisation } \\
\text { Deployment Project } \\
\text { (Humber-DP) }\end{array}$ & The Humber & $\begin{array}{c}\text { Humber Industrial } \\
\text { Decarbonisation } \\
\text { Roadmap }\end{array}$ & The Humber \\
\hline $\begin{array}{l}\text { HyNet Carbon Capture } \\
\text { Utilisation and Storage } \\
\text { (CCUS) }\end{array}$ & North West & $\begin{array}{l}\text { North West Hydrogen } \\
\text { and Energy Cluster: } \\
\text { Route to Net Zero }\end{array}$ & North West \\
\hline $\begin{array}{l}\text { South Wales Industrial } \\
\text { Cluster (SWIC) }\end{array}$ & Wales & $\begin{array}{l}\text { South Wales Industrial } \\
\text { Cluster (SWIC) }\end{array}$ & Wales \\
\hline $\begin{array}{l}\text { Green Hydrogen for } \\
\text { Humber }\end{array}$ & The Humber & $\begin{array}{l}\text { Repowering the Black } \\
\text { Country }\end{array}$ & Midlands \\
\hline $\begin{array}{r}\text { For the deployment competiti } \\
\text { a share of up to } f 1 \mathrm{~m} \text { to dev } \\
\text { industrial }\end{array}$ & $\begin{array}{l}\text { sinesses could apply for } \\
\text { for decarbonising an } \\
\text { 80]. }\end{array}$ & \multicolumn{2}{|c|}{$\begin{array}{l}\text { For the roadmaps competition, UK businesses could apply for a } \\
\text { share of up to } f 1 m \text { to prepare plans for their journey to } \\
\text { achieving low carbon and net zero industrial clusters [280]. }\end{array}$} \\
\hline
\end{tabular}

Table 18 - Overview of Winners from Phase One of UK Industrial Decarbonisation Challenge [198].

\section{The International Importance of Hydrogen}

So far, this article has focused on hydrogen technologies in a UK setting. However, at a global level, hydrogen has the potential to meet $18 \%$ of the world's energy demands and abate $6 \mathrm{Gt}$ of $\mathrm{CO}_{2}$ annually [8]. Therefore, hydrogen technologies must also be considered from an international perspective. This section briefly highlights recommendations for the development of a global hydrogen market as well as international collaboration platforms concerned with this agenda.

\subsection{Unlocking a Global Hydrogen Market}

The Future of Hydrogen report published by the International Energy Agency (IEA) urged that international hydrogen trade needs to start soon to make an impact on the global energy system [11]. Table 19 provides an overview of some key recommendations for developing a global hydrogen market.

\begin{tabular}{cc}
\hline Recommendation & Further Information \\
\hline Develop International Standards for Hydrogen & $\begin{array}{c}\text { Trade will benefit from common international } \\
\text { standards for the safety of the transportation and } \\
\text { storage of large volumes of hydrogen. }\end{array}$ \\
$\begin{array}{c}\text { Accounting standards for different sources of hydrogen } \\
\text { along the supply chain need to be developed on an } \\
\text { international basis. }\end{array}$ \\
$\begin{array}{c}\text { Harmonising hydrogen blend limits across borders is a } \\
\text { crucial step to support deployment as well as } \\
\text { accounting for possible variations in blending levels } \\
\text { over time. }\end{array}$ \\
$\begin{array}{c}\text { One third of global physical trade by sea are energy } \\
\text { products. This is an important contributor to climate } \\
\text { change. }\end{array}$ \\
$\begin{array}{c}\text { Lessons from the global liquified natural gas (LNG) } \\
\text { market can be leveraged for hydrogen shipment. }\end{array}$ \\
If governments work to scale up hydrogen in a co- \\
ordinated way, it will help investment in infrastructure, \\
bring down costs and enable the sharing of best \\
practices.
\end{tabular}


Table 19 - Recommendations for Developing a Global Hydrogen Market. Developed from [11].

\subsubsection{Co-Ordinated Cross Border Approaches}

In early 2020, German and French gas transmission system operators (TSO) signed a MoU to enhance knowledge and research sharing concerning the transportation and blending of hydrogen in their natural gas networks [281]. This agreement reinforces cross-border cooperation and is the most important to date at European Scale [282].

\subsubsection{International Shipping Routes}

Hydrogen can be produced, at low cost, in locations with the best resources available and then traded with consuming countries that lack the potential for affordable hydrogen production [283]. International shipping provides one option of transporting large volumes of hydrogen to consumers.

In 2019, as part of the Advanced Hydrogen Energy Chain Association for Technology Development (AHEAD) demonstration project, hydrogen was transported from Brunei to Japan. Hydrogen was produced at a hydrogenation plant and stored in the form of methylcyclohexane (MCH). It was then transported via shipment to Japan. In future, hydrogen will be extracted at a dehydrogenation plant and the resultant toluene will be returned to Brunei for reuse as a transport medium [284, 285].

As well as this, the Hydrogen Energy Supply Chain (HESC) project seeks to transport hydrogen from Australia to Japan through international shipping. Hydrogen will be produced from the gasification of brown coal in Latrobe Valley, Australia. It will then be transported to Port of Hastings, Australia where it will be liquefied and shipped to Japan. The pilot demonstration for this project is expected to run until 2021 [286].

In 2017, Kawasaki formed a partnership with Norway's Hel Hydrogen; with the backing of Mitsubishi Corporation and Statoil (now Equinor). The companies will carry out a feasibility study for a demonstration project which comprises the production of hydrogen from hydroelectric power, and eventually wind, in Norway. This will be transported via liquid hydrogen tanks to Japan [287].

\subsection{International Collaboration}

To build a safe and economical worldwide infrastructure for hydrogen networks, international collaboration will be required [288]. Table 20 provides an overview of some existing international hydrogen collaboration platforms.

\begin{tabular}{cc}
\hline $\begin{array}{c}\text { International Hydrogen Collaboration } \\
\text { Platform }\end{array}$ & Aim and/or Purpose \\
\hline $\begin{array}{c}\text { Mission Innovation - IC8: Renewable and Clean } \\
\text { Hydrogen }\end{array}$ & $\begin{array}{c}\text { To accelerate the development of a global hydrogen } \\
\text { market by identifying and overcoming key technology } \\
\text { barriers to the production, distribution, storage, and } \\
\text { use of hydrogen at gigawatt scale [289]. }\end{array}$ \\
$\begin{array}{c}\text { International Energy Agency (IEA) Hydrogen Technology } \\
\text { Collaboration Programme (TCP) }\end{array}$ & $\begin{array}{c}\text { To enable governments and industries from around the } \\
\text { world to lead programmes and projects on a wide range } \\
\text { of energy technologies and related issues [290]. }\end{array}$ \\
$\begin{array}{c}\text { International Partnership for Hydrogen and Fuel Cells in } \\
\text { the Economy (IPHE) }\end{array}$ & $\begin{array}{c}\text { To facilitate and accelerate the transition to clean and } \\
\text { efficient energy and mobility systems using hydrogen } \\
\text { and fuel cell technologies across applications and } \\
\text { sectors [291]. }\end{array}$ \\
\end{tabular}


Hydrogen Europe (European Hydrogen and Fuel Cell Association)

U.S. Deparment of Energy's (DOE) Fuel Cell Technologies Office

Fuel Cell and Hydrogen Joint Undertaking (FCH JU)

Hydrogen Council

Hydrogen Global Charter
To play a crucial role in promoting best practice, helping companies become more competitive and formulating effective public policy.

To provide the necessary intelligence and a solid network in order to support their members [292].

To advance hydrogen and fuel cells for transportation and diverse applications enabling energy security, resiliency, and a strong domestic economy in emerging technologies [293].

To demonstrate fuel cell and hydrogen technologies as one of the pillars of future European energy and transport systems, making a valued contribution to the transformation to a low carbon economy by 2050 [294].

To accelerate the development and commercialization of the hydrogen and fuel cell sectors.

To encourage key stakeholders to increase their backing of hydrogen as part of the future energy mix [295].

To deliver impact by forming a community of hydrogen actors around a shared commitment: consume, enable, and invest in blue and green hydrogen [296].

Table 20 - Overview of International Hydrogen Collaboration Platforms.

\section{Conclusion}

Despite considerable reductions in territorial greenhouse gas emissions in recent years, the UK must urgently decarbonise heavy emitting sectors to meet ambitious net-zero targets. Hydrogen can complement other low-carbon technologies in this effort. Though, it may not be a 'silver bullet' solution, it can address some of the challenges exhibited by alternate technologies, particularly in the transport and domestic sector. At present, BEVs cannot compete with the long driving ranges and short refuelling times exhibited by HFC vehicles. This creates a potential market for HFC vehicles where minimum refuelling times are required to avoid loss of earnings. In the short term, this could encompass buses, trains and heavy-goods vehicles. Furthermore, hydrogen has the potential to be produced at a large enough scale to accommodate future heat demand. This could address challenges faced by heat pumps such as the requirements for increased electricity generation and storage capacity as well as the intermittent availability of renewable energy. Several hydrogen technologies are now commercially available; most of which have applications within the transport sector. However, there is significant room for improvement in terms of the availability of required infrastructure as well as hydrogen compatible appliances for both domestic and industrial heat. Both of which will be essential in delivering the hydrogen economy.

There are multiple options for hydrogen production, delivery and storage pathways. Each of which have trade-offs in terms of scale, efficiency, cost and technological maturity. The most optimal technology will be dependent on the specific requirements of individual projects. In the UK, reforming technologies are expected to dominate immediate future hydrogen production. Research indicates that the LCH system is best suited for blue hydrogen production due to higher carbon capture potential at lower costs in comparison to other reforming technologies with CCS. However, other than the sources identified throughout, there is a lack of academic literature concerning this technology which stresses the importance of future research. Whilst there are no operational LSIP hydrogen projects in the UK, several initiatives have been proposed and are due to reach the FEED and FID stage in the next couple of years: subject to government funding. 
The potential role of hydrogen has been recognised by UK government through various strategy documents and has also been supported through numerous funding streams. Despite this, policy incentives received for hydrogen are minimal in contrast to other low-carbon technologies. As hydrogen is anticipated to heavily decarbonise various sectors, additional policy support is necessary. Furthermore, there is no definitive outline of the role hydrogen, will have in the UK's decarbonisation strategy to 2050 and beyond thus emphasising the need for a UK-wide hydrogen strategy. This calls for significant improvements in hydrogen policy which will require a coordinated, cross-departmental approach from government alongside consultations with numerous stakeholders including academia, business and industry. Likewise, this level of collaboration will be required for the establishment of new hydrogen codes, standards and regulations. To facilitate hydrogen in the existing energy system, exemptions and amendments to existing legislations will be required. This will in turn address risk uncertainties, help secure investment and, eventually, drive down costs. From the literature reviewed, the following policy and regulatory recommendations are outlined to enhance investor confidence in hydrogen technologies and subsequently accelerate the development of a hydrogen economy in the UK:

1) Create a UK-wide hydrogen strategy which provides clarity on the future role(s) of hydrogen

2) Identify a suitable hydrogen business model

3) Adopt a cross-departmental approach to develop policy mechanisms and regulation which are supportive of, and promote, hydrogen technologies and hydrogen as a low-carbon fuel.

The general public will heavily influence the success of hydrogen technologies in the UK and must not be neglected in this transition. Generally, research suggests that the public recognise the potential of hydrogen in addressing environmental issues and current energy system flaws. However, installation burdens, unfamiliar experiences and high costs associated with hydrogen could negatively affect public acceptance. The social acceptance of hydrogen utilised within the home has been explored in the UK as part of the wider HyDeploy and $\mathrm{H} 21$ initiatives. Whilst there is an abundance of literature concerning the public perception of hydrogen in the transport sector at a global level, there is limited literature available for a UK context. Further research into the public acceptance of hydrogen technologies in the UK is required and could be extended to include its other applications such as industrial fuel switching and power generation.

Industrial clusters are recognised as immediate areas of focus to kick-start the global hydrogen economy due to their proximity to existing oil and gas facilities. The international trade of hydrogen must happen soon to have an impact on the global energy system. Co-ordinated approaches are encouraged to promote harmonised international standards for hydrogen and develop international shipping routes. This could progress export opportunities. International collaboration is already exhibited through numerous platforms which collectively encompass individual nations, governments, academic institutes and businesses from around the globe.

This review article set out to address an existing literature gap concerning the lack of research on hydrogen that adopts a multi-disciplinary approach. In doing so, this review has facilitated a wider conversation around hydrogen technologies in the UK by encompassing technical, policy, regulatory and social discussions. To appreciate the wider context of hydrogen, future research could benefit from adopting this approach.

\section{Acknowledgements}

The authors would like to thank Terry Tomlinson and Adrian Finn of Costain for their review and comments on this article. 


\section{Role of Funding}

This work was supported as part of a wider strategic relationship between Costain, Manchester, UK and the University of Chester, UK.

\section{References}

1. Ritchie, H. and M. Roser. CO2 and greenhouse gas emissions 2019 [cited 2020 7th June]; Available from: https://ourworldindata.org/co2-and-other-greenhouse-gas-emissions.

2. IEA. Global energy \& CO2 status report 2019. 2019; Available from: https://www.iea.org/reports/global-energy-and-co2-statusreport-2019.

3. IPCC. Global warming of $1.5^{\circ} \mathrm{C}$ : Headline statements from the summary for policy makers. 2018; p.1]. Available from: https://www.ipcc.ch/site/assets/uploads/sites/2/2019/06/SR15 Headline-statements.pdf.

4. UNFCCC. The Paris Agreement 2019 [cited 2019 31st Jan ]; Available from: https://unfccc.int/process/the-parisagreement/what-is-the-paris-agreement.

5. UNEP. Emissions Gap Report 20192019 p.13]. Available from: http://www.unenvironment.org/emissionsgap.

6. Blanco, H., et al. Potential for hydrogen and Power-to-Liquid in a low-carbon EU energy system using cost optimization. Applied Energy, 2018. 232, 617-639 DOI: https://doi.org/10.1016/j.apenergy.2018.09.216.

7. IEA. Global CO2 emissions by sector, 20182020 31st July 2020 [cited 2020 25th October 2020 ]; Available from: https://www.iea.org/data-and-statistics/charts/global-co2-emissions-by-sector-2018.

8. Hydrogen Council. Hydrogen scaling up A sustainable pathway for the global energy transition, 2017; p.7-11]. Available from: https://hydrogencouncil.com/wp-content/uploads/2017/11/Hydrogen-Scaling-up_Hydrogen-Council 2017.compressed.pdf.

9. J. Bockris The hydrogen economy. Environmental Chemistry 1977. DOI: https://doi.org/10.1007/978-1-4615-6921-3 17.

10. IEA. Hydrogen 2020 [cited 2020 24th Feb]; Available from: https://www.iea.org/fuels-and-technologies/hydrogen.

11. IEA. The Future of Hydrogen 2019; Available from: https://www.iea.org/publications/reports/thefutureofhydrogen/.

12. BEIS. 2019 UK Greenhouse Gas Emissions, Provisional Figures Statistical Release: National Statistics 2020; Available from: https://assets.publishing.service.gov.uk/government/uploads/system/uploads/attachment data/file/875485/2019 UK greenh ouse gas emissions provisional figures statistical release.pdf.

13. BEIS. 2018 UK Greenhouse Gas Emissions. 2020; Available from: https://assets.publishing.service.gov.uk/government/uploads/system/uploads/attachment data/file/863325/2018-finalemissions-statistics-summary.pdf.

14. BEIS. 6. Renewables: Table 6.1 Renewable electricity capacity and generation. 2020 [cited 25th October 2020]; Microsoft Excel Spreadhseet ]. Available from:

https://assets.publishing.service.gov.uk/government/uploads/system/uploads/attachment_data/file/743592/ET 6.1.xls.

15. CCC. Net zero: The UK's contribution to stopping global warming 2019; p. 214]. Available from: https://www.theccc.org.uk/publication/net-zero-the-uks-contribution-to-stopping-global-warming/.

16. CCC. Net Zero Technical Report 2019; Available from: https://www.theccc.org.uk/wp-content/uploads/2019/05/Net-ZeroTechnical-report-CCC.pdf.

17. DEFRA and DfT. UK plan for tackling roadside nitrogen dioxide concentrations: An overview 2017; p.5]. Available from: https://assets.publishing.service.gov.uk/government/uploads/system/uploads/attachment data/file/633269/air-quality-planoverview.pdf?forcedefault=true.

18. DfT. Consulting on ending the sale of new petrol, diesel and hybrid cars and vans. 202020 th February 2020 [cited 202011 th June ]; Available from: https://www.gov.uk/government/consultations/consulting-on-ending-the-sale-of-new-petrol-dieseland-hybrid-cars-and-vans.

19. Vehicle Certification Agency. Zero and Ultra Low Emission Vehicles (ULEVs). 2020 28th May 2020 [cited 202011 th June ]; Available from: https://www.vehicle-certification-agency.gov.uk/fcb/ulev.asp.

20. U.S. Department of Energy. How Do Fuel Cell Electric Vehicles Work Using Hydrogen? n.d. [cited 2019 2nd Feb ]; Available from: https://afdc.energy.gov/vehicles/how-do-fuel-cell-electric-cars-work.

21. EERE. Alternative Fuels Data Center. Hydrogen Benefits and Considerations 2016 [cited 2020 11th June ]; Available from: https://afdc.energy.gov/fuels/hydrogen benefits.html.

22. Staffell, l., et al. The role of hydrogen and fuel cells in the global energy system. Energy \& Environmental Science, 2019. 12, 463491 DOI: 10.1039/C8EE01157E.

23. UK H2 Mobility. UK H2 Mobility: Phase 1 Results 2013; Available from: https://assets.publishing.service.gov.uk/.

24. Burke, J. and M. Rooney. Fuelling the Future: Hydrogen's role in supporting the low-carbon economy 2018; Available from: https://policyexchange.org.uk.

25. DfT. Department for Transport statistics. 2020; Available from: https://assets.publishing.service.gov.uk/government/uploads/system/uploads/attachment data/file/853467/veh0170.ods.

26. Howard, R., et al. Driving Down Emissions 2017; Available from: https://policyexchange.org.uk/wp-content/uploads.

27. Ajanovic, A. and R. Haas, Economic and Environmental Prospects for Battery Electric-and Fuel Cell Vehicles: A Review. Fuel Cells, 2019. 19(5): p. 515-529.

28. TUV SUD. Hydrogen Refuelling Stations Worldwide. 2019 30/01/2019 [cited 2019 2nd Feb ]; Available from: https://www.netinform.net/h2/h2stations/Default.aspx.

29. Logan, K.G., J.D. Nelson, and A. Hastings Electric and hydrogen buses: Shifting from conventionally fuelled cars in the UK. Transportation Research Part D: Transport and Environment, 2020. 85, 102350 DOI: https://doi.org/10.1016/j.trd.2020.102350.

30. Thomas, J.M., et al. Decarbonising energy: The developing international activity in hydrogen technologies and fuel cells. Journal of Energy Chemistry, 2020. 51, 405-415 DOI: https://doi.org/10.1016/j.jechem.2020.03.087.

31. Correa, G., P.M. Muñoz, and C.R. Rodriguez A comparative energy and environmental analysis of a diesel, hybrid, hydrogen and electric urban bus. Energy, 2019. 187, 115906 DOI: https://doi.org/10.1016/j.energy.2019.115906.

32. Ricardo. Hydrogen for Transport Programme (HTP). 2019 [cited 2019 2nd Feb ]; Available from: https://ee.ricardo.com/htpgrants. 
34. Hirschlag, A. Next stop, hydrogen-powered trains. 2020; 27th February 2020 ]. Available from:

https://www.bbc.com/future/article/20200227-how-hydrogen-powered-trains-can-tackle-climatechange\#: :text=The\%20train\%2C\%20called\%20Hydroflex\%2C\%20is, upon\%2DAvon\%2C\%20in\%20England.

35. Flaig, J. Hydrogen trains could run in UK by 2021 after Alstom and Eversholt confirm plans 2019 [cited 201920 th May ]; Available from: https://dev.imeche.org/news/news-article/hydrogen-trains-could-run-in-uk-by-2021-after-alstom-andeversholt-confirm-plans.

36. El Hannach, M., et al. Life cycle assessment of hydrogen and diesel dual-fuel class 8 heavy duty trucks. International Journal of Hydrogen Energy, 2019. 44, 8575-8584 DOI: https://doi.org/10.1016/j.ijhydene.2019.02.027.

37. Lee, D.-Y., et al. Life-cycle implications of hydrogen fuel cell electric vehicle technology for medium-and heavy-duty trucks. Journal of Power Sources, 2018. 393, 217-229 DOI: https://doi.org/10.1016/j.jpowsour.2018.05.012.

38. Smallbone, A., et al. The impact of disruptive powertrain technologies on energy consumption and carbon dioxide emissions from heavy-duty vehicles. Energy Conversion and Management: X, 2020. 6, 100030 DOI: https://doi.org/10.1016/j.ecmx.2020.100030.

39. Ulemco. Products H2ICED 2017; Available from: https://ulemco.com/?page id=2568.

40. van Biert, L., et al. A review of fuel cell systems for maritime applications. Journal of Power Sources, 2016. 327, 345-364 DOI: https://doi.org/10.1016/i.jpowsour.2016.07.007.

41. Inal, O.B. and C. Deniz Assessment of fuel cell types for ships: Based on multi-criteria decision analysis. Journal of Cleaner Production, 2020. 265, 121734 DOI: https://doi.org/10.1016/j.jclepro.2020.121734.

42. Bicer, Y. and I. Dincer Environmental impact categories of hydrogen and ammonia driven transoceanic maritime vehicles: A comparative evaluation. International Journal of Hydrogen Energy, 2018. 43, 4583-4596 DOI: https://doi.org/10.1016/j.ijhydene.2017.07.110.

43. Baroutaji, A., et al. Comprehensive investigation on hydrogen and fuel cell technology in the aviation and aerospace sectors. Renewable and Sustainable Energy Reviews, 2019. 106, 31-40 DOI: https://doi.org/10.1016/j.rser.2019.02.022.

44. Ranasinghe, K., et al. Review of advanced low-emission technologies for sustainable aviation. Energy, 2019. 188, 115945 DOI: https://doi.org/10.1016/j.energy.2019.115945.

45. Contreras, A., et al. Hydrogen as aviation fuel: A comparison with hydrocarbon fuels. International Journal of Hydrogen Energy, 1997. 22, 1053-1060 DOI: https://doi.org/10.1016/S0360-3199(97)00008-6.

46. Fuel Cell Technologies Office. Early Markets: Fuel Cells for Material Handling Equipment. 201611 th June Available from: https://www.energy.gov/sites/prod/files/2016/12/f34/fcto early markets mhe fact sheet.pdf.

47. Williams, R. Hydrogen and Fuel Cells for Material Handling Applications. 2017; p.5]. Available from: https://www.fch.europa.eu/sites/default/files/Ranjieve\%20williams.pdf.

48. Lototskyy, M.V., et al. Metal hydride hydrogen storage and supply systems for electric forklift with low-temperature proton exchange membrane fuel cell power module. International Journal of Hydrogen Energy, 2016. 41, 13831-13842 DOI: https://doi.org/10.1016/j.ijhydene.2016.01.148.

49. Lototskyy, M.V., et al. Performance of electric forklift with low-temperature polymer exchange membrane fuel cell power module and metal hydride hydrogen storage extension tank. Journal of Power Sources, 2016. 316, 239-250 DOI: https://doi.org/10.1016/j.jpowsour.2016.03.058.

50. Haghi, E., et al. Assessing the potential of fuel cell-powered and battery-powered forklifts for reducing GHG emissions using clean surplus power; a game theory approach. International Journal of Hydrogen Energy, 2020. DOI: https://doi.org/10.1016/j.ijhydene.2019.05.063.

51. BEIS. Energy Consumption in the UK (ECUK). Table U3: Domestic; consumption by end use and fuel 1990 to 20182019 ; Available from:

https://assets.publishing.service.gov.uk/government/uploads/system/uploads/attachment data/file/826726/2019 End use t ables 2.xIsx.

52. Watson, S.D., K.J. Lomas, and R.A. Buswell Decarbonising domestic heating: What is the peak GB demand? Energy Policy, 2019. 126, 533-544 DOI: https://doi.org/10.1016/j.enpol.2018.11.001.

53. Hydrogen Europe. Green Heating and Cooling. [cited 2020 11th June ]; Available from: https://hydrogeneurope.eu/greenheating-and-cooling.

54. Samsatli, S. and N.J. Samsatli The role of renewable hydrogen and inter-seasonal storage in decarbonising heatComprehensive optimisation of future renewable energy value chains. Applied Energy, 2019. 233-234, 854-893 DOI: https://doi.org/10.1016/j.apenergy.2018.09.159.

55. Wilson, I.A.G., et al. Historical daily gas and electrical energy flows through Great Britain's transmission networks and the decarbonisation of domestic heat. Energy Policy, 2013. 61, 301-305 DOI: https://doi.org/10.1016/j.enpol.2013.05.110.

56. KPMG. 2050 Energy scenarios. 2016; Available from: https://www.energynetworks.org/assets/files/gas/futures/KPMG\%20Future\%20of\%20Gas\%20Main\%20report\%20plus\%20app endices\%20FINAL.pdf.

57. National Grid. Contribution to decarbonisation. 2020 [cited 2020 30th June]; Available from: https://www.nationalgrid.com/uk/electricity-transmission/working-together/our-environmental-future/contribution-todecarbonisation.

58. Evans, S. Analysis: Record-low price for UK offshore wind cheaper than existing gas plants by 20232019 [cited 202030 th June ]; Available from: https://www.carbonbrief.org/analysis-record-low-uk-offshore-wind-cheaper-than-existing-gas-plants-by-2023.

59. Dorrington, M., et al. DECC Desk study on the deelopment of a hydrogen-fired appliance supply chain 2016; Available from: https://www.gov.uk/government/publications/hydrogen-appliances-desk-study-on-the-development-of-the-supply-chain-for100-hydrogen-fired-domestic-and-commercial-appliances.

60. Mcintosh, A. SGN Energy Futures 2018; Available from: https://www.kiwa.com/nl/globalassets/netherlands/kiwatechnology/downloads/sgc---energy-futures-presentation-h2---netherlands.pdf. 
61.

62.

63.

64.

65

66.

67

68.

69.

70.

71.

72.

73

74.

75.

76.

77.

78.

79.

80.

81

82.

83

84

85.

86.

87.

88.

89.

90.

91.

92.

93.

94.

Heap, C. Hy4Heat (WP2) - Standards, Purity \& Colourant 2019; p.28]. Available from: https://www.hy4heat.info/s/ARP-WP4STK-PRS-0005-zmsg.pdf.

Deymi-Dashtebayaz, M., et al. Investigating the effect of hydrogen injection on natural gas thermo-physical properties with various compositions. Energy, 2019. 167, 235-245 DOI: https://doi.org/10.1016/j.energy.2018.10.186.

Zhao, Y., V. McDonell, and S. Samuelsen Influence of hydrogen addition to pipeline natural gas on the combustion performance of a cooktop burner. International Journal of Hydrogen Energy, 2019. 44, 12239-12253 DOI: https://doi.org/10.1016/j.ijhydene.2019.03.100.

de Vries, H., A.V. Mokhov, and H.B. Levinsky The impact of natural gas/hydrogen mixtures on the performance of end-use equipment: Interchangeability analysis for domestic appliances. Applied Energy, 2017. 208, 1007-1019 DOI:

https://doi.org/10.1016/j.apenergy.2017.09.049.

Witkowski, A., et al. Analysis of compression and transport of the methane/hydrogen mixture in existing natural gas pipelines International Journal of Pressure Vessels and Piping, 2018. 166, 24-34 DOI: https://doi.org/10.1016/j.ijpvp.2018.08.002. Witkowski, A., et al. Comprehensive analysis of hydrogen compression and pipeline transportation from thermodynamics and safety aspects. Energy, 2017. 141, 2508-2518 DOI: https://doi.org/10.1016/j.energy.2017.05.141. CCC. Hydrogen in a low-carbon economy. 2018; Available from: https://www.theccc.org.uk.

Element Energy and Jacobs. Industrial Fuel Switching Market Engagement Study 2018; Available from: https://assets.publishing.service.gov.uk/.

Element Energy, Jacobs, and Cardiff University. Hy4Heat WP6: Understanding Industrial Appliances Industry Workshop 2019; Available from: https://sturgeon-tuna-ezsb.squarespace.com/s/BEIS-Hy4Heat-WP6-industry-workshop-handout-F.pdf. BEIS. Industrial Fuel Switching competition phase 3: successful projects 2020 [cited 2020 30th June]; Available from: https://www.gov.uk/government/publications/industrial-fuel-switching-to-low-carbon-alternatives/industrial-fuel-switchingdemonstration-successful-projects-phase-3.

Luh, S., et al. Long-term development of the industrial sector - Case study about electrification, fuel switching, and CCS in the USA. Computers \& Chemical Engineering, 2020. 133, 106602 DOI: https://doi.org/10.1016/j.compchemeng.2019.106602. Griffin, P.W. and G.P. Hammond Industrial energy use and carbon emissions reduction in the iron and steel sector: A UK perspective. Applied Energy, 2019. 249, 109-125 DOI: https://doi.org/10.1016/j.apenergy.2019.04.148.

Han, Y., B. Shen, and T. Zhang A Techno-economic Assessment of Fuel Switching Options of Addressing Environmental Challenges of Coal-Fired Industrial Boilers: An analytical work for China. Energy Procedia, 2017. 142, 3083-3087 DOI: https://doi.org/10.1016/j.egypro.2017.12.448.

Moya, D., et al. Agent-based scenarios comparison for assessing fuel-switching investment in long-term energy transitions of the India's industry sector. Applied Energy, 2020. 274, 115295 DOI: https://doi.org/10.1016/j.apenergy.2020.115295.

BEIS. Digest of United Kingdom Energy Statistics 2018 Chapter 5: Electricity 2019; p.80]. Available from: https://assets.publishing.service.gov.uk/government/uploads/system/uploads/attachment data/file/820708/Chapter 5.pdf. National Grid. Future Energy Scenarios 2019; Available from: http://fes.nationalgrid.com/media/1409/fes-2019.pdf. 204, 47-65 DOI: https://doi.org/10.1016/j.apenergy.2017.06.098.

Runyon, J. Hydrogen Power Generation - Challenges and Prospects for 100\% Hydrogen Gas Turbines. 2020; p.1-21]. Available from: https://ukccsrc.ac.uk/wp-content/uploads/2020/05/Jon-Runyon-CCS-and-Hydrogen.pdf.

. Welch. Hydrogen as a Fuel for Gas Turbines. 2020; Available from:

https://www.thechemicalengineer.com/features/hydrogen-as-a-fuel-for-gas-turbines/.

Taamallah, S., et al. Fuel flexibility, stability and emissions in premixed hydrogen-rich gas turbine combustion: Technology, fundamentals, and numerical simulations. Applied Energy, 2015. 154, 1020-1047 DOI:

https://doi.org/10.1016/j.apenergy.2015.04.044.

Wang, J., H. Wang, and Y. Fan Techno-Economic Challenges of Fuel Cell Commercialization. Engineering, 2018. 4, 352-360 DOI: https://doi.org/10.1016/j.eng.2018.05.007.

Bao, C., et al. Macroscopic modeling of solid oxide fuel cell (SOFC) and model-based control of SOFC and gas turbine hybrid system. Progress in Energy and Combustion Science, 2018. 66, 83-140 DOI: https://doi.org/10.1016/j.pecs.2017.12.002. Ramadhani, F., et al. Optimization strategies for Solid Oxide Fuel Cell (SOFC) application: A literature survey. Renewable and Sustainable Energy Reviews, 2017. 76, 460-484 DOI: https://doi.org/10.1016/j.rser.2017.03.052.

ERP. Potential role of hydrogen in the UK energy system 2016; p.18-20]. Available from: http://erpuk.org/wpcontent/uploads/2016/10/ERP-Hydrogen-report-Oct-2016.pdf.

Quaschning, V., Regenerative Energiesysteme: Technologie - Berechnung - Simulation [Book]. 2015, Hanser Fachbuchverlag. Leung, D.Y.C., G. Caramanna, and M.M. Maroto-Valer An overview of current status of carbon dioxide capture and storage technologies. Renewable and Sustainable Energy Reviews, 2014. 39, 426-443 DOI: https://doi.org/10.1016/j.rser.2014.07.093. Anwar, M.N., et al. CO2 capture and storage: A way forward for sustainable environment. Journal of Environmental Management, 2018. 226, 131-144 DOI: https://doi.org/10.1016/j.jenvman.2018.08.009.

Nikolaidis, P. and A. Poullikkas A comparative overview of hydrogen production processes. Renewable and Sustainable Energy Reviews, 2017. 67, 597-611 DOI: https://doi.org/10.1016/j.rser.2016.09.044.

Pareek, A., et al. Insights into renewable hydrogen energy: Recent advances and prospects. Materials Science for Energy Technologies, 2020. 3, 319-327 DOI: https://doi.org/10.1016/j.mset.2019.12.002.

Turner, J., et al. Renewable hydrogen production. International Journal of Energy Research, 2008. 32, 379-407 DOI: 10.1002/er.1372.

1. Acar, C. and I. Dincer Review and evaluation of hydrogen production options for better environment. Journal of Cleaner Production, 2019. 218, 835-849 DOI: https://doi.org/10.1016/i.jclepro.2019.02.046.

El-Shafie, M.I., S. Kambara, and Y. Hayakawa Hydrogen Production Technologies Overview Journal of Power and Energy Engineering 2019. 107-154 DOI: 10.4236/jpee.2019.71007.

Speirs, J., et al. A greener gas grid: What are the options 2017; Available from: https://www.sustainablegasinstitute.org/wpcontent/uploads/2017/06/SGI-A-greener-gas-grid-what-are-the-options-WP3.pdf?noredirect=1.

Barelli, L., et al. Hydrogen production through sorption-enhanced steam methane reforming and membrane technology: $A$ review. Energy, 2008. 33, 554-570 DOI: https://doi.org/10.1016/j.energy.2007.10.018. 

Joensen, F. and J.R. Rostrup-Nielsen Conversion of hydrocarbons and alcohols for fuel cells. Journal of Power Sources, 2002. 105, 195-201 DOI: https://doi.org/10.1016/S0378-7753(01)00939-9. Kalamaras, C.M. and A.M. Efstathiou Hydrogen Production Technologies: Current State and Future Developments. Conference Papers in Energy, 2013. 2013, 9 DOI: 10.1155/2013/690627. 8-9.

99. Jagger, P. and N. Kittner Deforestation and biomass fuel dynamics in Uganda. Biomass and Bioenergy, 2017. 105, 1-9 DOI: https://doi.org/10.1016/j.biombioe.2017.06.005.

100. Brett, D.J.L., et al., 1 - Fuels and fuel processing for low temperature fuel cells, in Polymer Electrolyte Membrane and Direct Methanol Fuel Cell Technology, C. Hartnig and C. Roth, Editors. 2012, Woodhead Publishing. p. 3-26.

101. Cotton, B. Hydrogen from Natural Gas Through Cost Effective CO2 Capture Clean Hydrogen 2019; Available from: https://www.thechemicalengineer.com/features/clean-hydrogen-part-1-hydrogen-from-natural-gas-through-cost-effectiveco2-capture/.

102. Northern Gas Networks. H21 North of England 2018; Available from: https://www.northerngasnetworks.co.uk/h21-noe.

103. French, S. The hydrogen opportunity 2018 5th July 2019; Available from: https://matthey.com/inspiring-science/thoughts/thehydrogen-opportunity.

104. Finn, A., et al., Natural gas decarbonisation by efficient hydrogen generation with carbon capture, in GasTech 2019: Houston, Texas p. 7.

105. Bockris, O.M.J., E.B. Conway, and E. Yeager, Comprehensive Treatise of Electrochemistry, in Electrochemical Processing 1981, Plenum Press NY.

106. Ursua, A., L.M. Gandia, and P. Sanchis Hydrogen Production From Water Electrolysis: Current Status and Future Trends. Proceedings of the IEEE, 2012. 100, 410-426 DOI: 10.1109/JPROC.2011.2156750.

107. Element Energy. Hydrogen supply chain evidence base 2018; Available from: https://assets.publishing.service.gov.uk/government/uploads/system/uploads/attachment data/file/760479/H2 supply chain evidence - publication version.pdf.

108. Shiva Kumar, S. and V. Himabindu Hydrogen Production by PEM Water Electrolysis - A Review. Materials Science for Energy Technologies, 2019. DOI: https://doi.org/10.1016/j.mset.2019.03.002.

109. Wirkert, F.J., et al. A modular design approach for PEM electrolyser systems with homogeneous operation conditions and highly efficient heat management. International Journal of Hydrogen Energy, 2019. DOI: https://doi.org/10.1016/j.ijhydene.2019.03.185.

110. Carmo, M., et al. PEM water electrolysis: Innovative approaches towards catalyst separation, recovery and recycling. International Journal of Hydrogen Energy, 2019. 44, 3450-3455 DOI: https://doi.org/10.1016/j.ijhydene.2018.12.030.

111. Maric, R. and H. Yu, Proton Exchange Membrane Water Electrolysis as a Promising Technology for Hydrogen Production and Energy Storage, in Nanostructures in Energy Generation, Transmission and Storage Y. Fedorenko, Editor. 2019, IntechOpen, .

112. Schmidt, O., et al. Future cost and performance of water electrolysis: An expert elicitation study. International Journal of Hydrogen Energy, 2017. 42, 30470-30492 DOI: https://doi.org/10.1016/j.ijhydene.2017.10.045.

113. Kim, J., et al. Hybrid-solid oxide electrolysis cell: A new strategy for efficient hydrogen production. Nano Energy, 2018. 44, 121126 DOI: https://doi.org/10.1016/j.nanoen.2017.11.074.

114. Helmeth Project. High temperature electrolysis cell (SOEC). [cited 2020 28th April]; Available from: http://www.helmeth.eu/index.php/technologies/high-temperature-electrolysis-cell-soec.

115. Schmidt, O., et al., Future cost and performance of water electrolysis: An expert elicitation study. International Journal of Hydrogen Energy, 2017. 42(52): p. 30470-30492.

116. Buttler, A. and H. Spliethoff, Current status of water electrolysis for energy storage, grid balancing and sector coupling via power-to-gas and power-to-liquids: A review. Renewable and Sustainable Energy Reviews, 2018. 82: p. $2440-2454$.

117. Buttler, A. and H. Spliethoff Current status of water electrolysis for energy storage, grid balancing and sector coupling via power-to-gas and power-to-liquids: A review. Renewable and Sustainable Energy Reviews, 2018. 82, 2440-2454 DOI: https://doi.org/10.1016/j.rser.2017.09.003.

118. Schnuelle, C., et al. Socio-technical-economic assessment of power-to-X: Potentials and limitations for an integration into the German energy system. Energy Research \& Social Science, 2019. 51, 187-197 DOI: https://doi.org/10.1016/j.erss.2019.01.017.

119. Schmidt, P., et al. Power-to-Liquids as Renewable Fuel Option for Aviation: A Review. Chemie Ingenieur Technik, 2018. 90, 127140 DOI: 10.1002/cite.201700129.

120. Götz, M., et al. Renewable Power-to-Gas: A technological and economic review. Renewable Energy, 2016. 85, 1371-1390 DOI: https://doi.org/10.1016/j.renene.2015.07.066.

121. Qadrdan, M., et al. Role of power-to-gas in an integrated gas and electricity system in Great Britain. International Journal of Hydrogen Energy, 2015. 40, 5763-5775 DOI: https://doi.org/10.1016/j.ijhydene.2015.03.004.

122. EERE. Hydrogen Production: Biomass Gasification 2019 [cited 20195 July]; Available from: https://www.energy.gov/eere/fuelcells/hydrogen-production-biomass-gasification.

123. Howes, et al. Innovation Needs Assessment for Biomass Heat 2018; p.46-52]. Available from: https://assets.publishing.service.gov.uk/government/uploads/system/uploads/attachment data/file/699669/BE2 Innovation Needs Final report Jan18.pdf.

124. IPCC. Global Warming of $1.5^{\circ} \mathrm{C}$. 2018; Available from: https://www.ipcc.ch.

125. Hart, D., et al. Scenarios for deployment of hydrogen in contributing to meeting carbon budgets and the 2050 target. Final Report 2015; Available from: https://www.theccc.org.uk/wp-content/uploads/2015/11/E4tech-for-CCC-Scenarios-fordeployment-of-hydrogen-in-contributing-to-meeting-carbon-budgets.pdf.

126. El-Emam, R.S. and I. Dincer, Nuclear-Assisted Hydrogen Production, in Encyclopedia of Sustainability Science and Technology, R.A. Meyers, Editor. 2017, Springer New York: New York, NY. p. 1-11.

127. Sorgulu, F. and I. Dincer Cost evaluation of two potential nuclear power plants for hydrogen production. International Journal of Hydrogen Energy, 2018. 43, 10522-10529 DOI: https://doi.org/10.1016/j.ijhydene.2017.10.165. 
Preuster, P., A. Alekseev, and P. Wasserscheid Hydrogen Storage Technologies for Future Energy Systems. Annual Review of Chemical and Biomolecular Engineering, 2017. 8, 445-471 DOI: 10.1146/annurev-chembioeng-060816-101334. Ogden, J., et al. Natural gas as a bridge to hydrogen transportation fuel: Insights from the literature. Energy Policy, 2018. 115, 317-329 DOI: https://doi.org/10.1016/j.enpol.2017.12.049.

130. DOE. Energy Efficiency and Renewable Energy Hydrogen Storage 2017; Available from: www.hydrogenandfuelcells.energy.gov. Hydrogen Tools. Lower and Higher Heating Values of Fuels. Available from: https://h2tools.org/hyarc/calculator-tools/lowerand-higher-heating-values-fuels.

132. College of the Desert, Hydrogen Properties, in Hydrogen Fuel Cell Engines and Related Technologies, P.N.N. Laboratory, Editor. 2001, Office of Energy Efficiency and Renewable Energy. p. 13.

133 Adolf, J., et al. Shell Hydrogen Study. Energy of the Future? 2017.

Rivard, E., M. Trudeau, and K. Zaghib, Hydrogen Storage for Mobility: A Review. Materials, 2019. 12(12). Reuß, M., et al. Seasonal storage and alternative carriers: A flexible hydrogen supply chain model. Applied Energy, 2017. 200, 290-302 DOI: https://doi.org/10.1016/j.apenergy.2017.05.050.

136. Gerboni, R., Introduction to hydrogen transportation, in Compendium of Hydrogen Energy: Hydrogen Storage, Distribution and Infrastructure R.B. Gupta, A. Basile, and T.N. Veziroglu, Editors. 2016, Woodhead Publishing: Cambridge, United Kingdom p. 302-319.

137. Crotogino, F., et al., Large-Scale Hydrogen Underground Storage for Securing Future Energy Supplies, in 18th World Hydrogen Energy Conference 2010, D. Stolten and T. Grube, Editors. 2010, WHEC Essen, Germany

138. Ozarslan, A. Large-scale hydrogen energy storage in salt caverns. International Journal of Hydrogen Energy, 2012. 37, 1426514277 DOI: https://doi.org/10.1016/i.ijhydene.2012.07.111.

139. Andersson, J. and S. Grönkvist Large-scale storage of hydrogen. International Journal of Hydrogen Energy, 2019. 44, 1190111919 DOI: https://doi.org/10.1016/j.ijhydene.2019.03.063.

140. Aarnes, J., M. Eijgelaar, and E. Hektor. Hydrogen as an Energy Carrier An evaluation of emerging hydrogen value chains 2018; Available from: www.dnvgl.com.

141. Ahluwalia, R.K., et al. Supercritical cryo-compressed hydrogen storage for fuel cell electric buses. International Journal of Hydrogen Energy, 2018. 43, 10215-10231 DOI: https://doi.org/10.1016/j.ijhydene.2018.04.113.

142. Kunze, K. and O. Kircher. Cryo-Compressed Hydrogen Storage 2012; Available from: https://stfc.ukri.org/stfc/cache/file/F45B669C-73BF-495B-B843DCDF50E8B5A5.pdf.

143. Petitpas, G., et al. A comparative analysis of the cryo-compression and cryo-adsorption hydrogen storage methods. International Journal of Hydrogen Energy, 2014. 39, 10564-10584 DOI: https://doi.org/10.1016/i.ijhydene.2014.04.200.

144. Ahluwalia, R.K., et al. Technical assessment of cryo-compressed hydrogen storage tank systems for automotive applications. International Journal of Hydrogen Energy, 2010. 35, 4171-4184 DOI: https://doi.org/10.1016/j.ijhydene.2010.02.074.

145. Gardiner, M., Energy requirements for hydrogen gas compression and liquefaction as related to vehicle storage needs. 2009.

146. Adolf, J., et al., Shell Hydrogen Study, in Energy of the Future? 2017: Hamburg, Germany.

147. Carriveau, R. and D.S.K. Ting, Methane and Hydrogen for Energy Storage. 2016, Institution of Engineering and Technology.

148. Preuster, P., A. Alekseev, and P. Wasserscheid, Hydrogen Storage Technologies for Future Energy Systems. Annual Review of Chemical and Biomolecular Engineering, 2017. 8(1): p. 445-471.

149. Dagdougui, H., et al., Chapter 4 - Hydrogen Storage and Distribution: Implementation Scenarios, in Hydrogen Infrastructure for Energy Applications, H. Dagdougui, et al., Editors. 2018, Academic Press. p. 37-52.

150. Ahluwalia, R.K., et al., Technical Assessment of Cryo-Compressed Hydrogen Storage Tank Systems for Automotive Applications, in Nuclear Engineering Division. 2009: Oak Ridge, TN.

151. Niermann, M., et al. Liquid organic hydrogen carriers (LOHCS) - techno-economic analysis of LOHCs in a defined process chain. Energy \& Environmental Science, 2019. 12, 290-307 DOI: 10.1039/C8EE02700E.

152. Carriveau, R. and D.S.K. Ting, 1.1 Towards a Hydrogen Economy, in Methane and Hydrogen for Energy Storage. 2016, Institution of Engineering and Technology

153. Niaz, S., T. Manzoor, and A.H. Pandith Hydrogen storage: Materials, methods and perspectives. Renewable and Sustainable Energy Reviews, 2015. 50, 457-469 DOI: https://doi.org/10.1016/j.rser.2015.05.011.

154. Weeda, M. and A. Elgowainy, Large-Scale Hydrogen Delivery Infrastructure 2015, International Energy Agency,

155. Hydrogen Europe. Hydrogen transport \& distribution 2017 [cited 2019 13th May ]; Available from: https://hydrogeneurope.eu/hydrogen-transport-distribution.

156. Campbell, J. Questions and Issues on Hydrogen Pipelines 2005; Available from: https://www.energy.gov/sites/prod/files/2014/03/f10/hpwgw questissues campbell.pdf.

157. National Academy of Engineering, Transportation, Distribution, and Storage of Hydrogen in The Hydrogen Economy: Opportunities, Costs, Barries and R\&D Needs N.A.o. Engineering, Editor. 2004, The National Academies Press: Washington, DC. p. 54-61.

158. HyDeploy. HyDeploy. Why is Keele Involved? 2020 [cited 2020 20th Feb]; Available from: https://hydeploy.co.uk/hydrogen/.

159. GRT. Technical and economic conditions for injecting hydrogen into natural gas networks 2019; p.5]. Available from: https://www.grtgaz.com/fileadmin/plaquettes/en/2019/Technical-economic-conditions-for-injecting-hydrogen-into-naturalgas-networks-report2019.pdf.

160. FCH. Development of business cases for fuel cells and hydrogen applications for regions and cities. 2017; p.8]. Available from: https://www.fch.europa.eu/sites/default/files/FCH\%20Docs/171121 FCH2JU ApplicationPackage WG5 P2H Hydrogen\%20into\%20gas\%20grid\%20\%28ID\%202910558\%29\%20\%28ID\%202911642\%29.pdf.

161. Melaina, M.W., O. Antonia, and M. Penev. Blending hydrogen into natural gas pipeline networks: A review of key issues 2013; Available from: https://www.energy.gov/sites/prod/files/2014/03/f11/blending h2 nat gas pipeline.pdf.

162. Teichmann, D. The missing link in the hydrogen economy? . 2019; p.36-39]. Available from: https://www.gasworld.com/themissing-link-in-the-hydrogen-economy/2017035.article.

163. Hydrogenious Technologies. Applications for a Hydrogen World 2019 [cited 2019 13th May ]; Available from: https://www.hydrogenious.net/index.php/en/hydrogen-mobility-applications/\#anchor_application_refuelling. USDRIVE. Hydrogen Delivery Technical Team Roadmap 2013; Available from: https://www.energy.gov/eere/vehicles/downloads/us-drive-hydrogen-delivery-technical-team-roadmap. 
165. USDRIVE. Hydrogen Delivery Technical Team Roadmap 2017; Available from:

https://www.energy.gov/sites/prod/files/2017/08/f36/hdtt roadmap_July2017.pdf. 166. Gondal, I.A., Hydrogen Transportation by Pipelines in Compendium of Hydrogen Energy: Hydrogen Storage, Distribution and
Infrastructure R.B. Gupta, A. Basile, and T.N. Veziroglu, Editors. 2016, Woodhead Publishing: Cambridge, United Kingdom. p. 320-341.

167. Paladino, O., et al. Hazard and risk evaluation in hydrogen pipelines. Management of Environmental Quality: An International Journal, 2010. 21, 712-725 DOI: 10.1108/14777831011067971.

168. Abdin, Z., et al. Hydrogen as an energy vector. Renewable and Sustainable Energy Reviews, 2020. 120, 109620 DOI: https://doi.org/10.1016/j.rser.2019.109620.

169. CCC. Net Zero: The UK's contribution to stopping global warming 2019; Available from: https://www.theccc.org.uk/wpcontent/uploads/2019/05/Net-Zero-The-UKs-contribution-to-stopping-global-warming.pdf.

170. Ajanovic, A. and R. Haas Economic prospects and policy framework for hydrogen as fuel in the transport sector. Energy Policy, 2018. 123, 280-288 DOI: https://doi.org/10.1016/j.enpol.2018.08.063.

171. Jones, J., A. Genovese, and A. Tob-Ogu Hydrogen vehicles in urban logistics: A total cost of ownership analysis and some policy implications. Renewable and Sustainable Energy Reviews, 2020. 119, 109595 DOI: https://doi.org/10.1016/j.rser.2019.109595.

172. Chapman, A., et al. Societal penetration of hydrogen into the future energy system: Impacts of policy, technology and carbon targets. International Journal of Hydrogen Energy, 2020. 45, 3883-3898 DOI: https://doi.org/10.1016/j.ijhydene.2019.12.112.

173. C2ES. U.S. State Greenhouse Gas Emissions Targets 2019 [cited 2020 14th May ]; Available from: https://www.c2es.org/document/greenhouse-gas-emissions-targets/.

174. UNFCCC. Kyoto Protocol Reference Manual 2008; Available from: https://unfccc.int/resource/docs/publication.

175. DECC. UK progress towards GHG emissions reduction targets 2015; p.3]. Available from:

https://assets.publishing.service.gov.uk/.

176. CCC. Global Action on Climate Change [cited 2019 31st Jan ]; Available from: https://www.theccc.org.uk/tackling-climatechange/the-legal-landscape/global-action-on-climate-change/.

177. European Commission. Kyoto 2nd commitment period (2013-20) 2020 [cited 2020 24th Feb ]; Available from: https://ec.europa.eu/clima/policies/strategies/progress/kyoto_2 en.

178. HM Government. The Climate Change Act 2008 (2050 Target Amendment) Order 2019. 1056 2019; Available from: https://www.legislation.gov.uk/uksi/2019/1056/contents/made.

179. CCC. Carbon budgets: How we monitor emissions targets 2020 [cited 2020 12th Feb ]; Available from: https://www.theccc.org.uk/tackling-climate-change/reducing-carbon-emissions/carbon-budgets-and-targets/.

180. CCC. Advice on the Sixth Carbon Budget Coming Up 2020 [cited 2020 25th October ]; Available from: https://www.theccc.org.uk/comingup/advice-on-the-sixth-carbonbudget/\#: :text=The\%20Committee\%20on\%20Climate\%20Change, during\%20the\%20period\%202033\%2D2037.

181. Bleischwitz, R. and N. Bader Policies for the transition towards a hydrogen economy: the EU case. Energy Policy, 2010. 38, 53885398 DOI: https://doi.org/10.1016/j.enpol.2009.03.041.

182. Rissman, J., et al. Technologies and policies to decarbonize global industry: Review and assessment of mitigation drivers through 2070. Applied Energy, 2020. 266, 114848 DOI: https://doi.org/10.1016/j.apenergy.2020.114848.

183. Harvey, H., R. Orvis, and J. Rissman, Designing climate solutions: a policy guide for low-carbon energy. 2018: Island Press.

184. Commission, E. EU Emissions Trading System (EU ETS) 2020; Available from: https://ec.europa.eu/clima/policies/ets en.

185. BEIS. Meeting climate change requirements from 1 January 2021. 2020 28th April 2020 [cited 2020 18th May ]; Available from: https://www.gov.uk/government/publications/meeting-climate-change-requirements-if-theres-no-brexit-deal/meetingclimate-change-requirements-if-theres-no-brexit-deal\#no-deal-1.

186. HM Government. Industrial Strategy: Building a Britain fit for the future 2017; Available from: www.gov.uk/beis

187. HM Government. The Clean Growth Strategy Leading the way to a clean carbon future 2017; Available from: https://www.gov.uk/government/publications/clean-growth-strategy.

188. HM Government. CCUS Cost Challenge Taskforce. n.d. 27th Jan 2019]; Available from: https://www.gov.uk/government/groups/ccus-cost-challenge-taskforce.

189. CCUS Cost Challenge Task Force. Delivering Clean Growth: CCUS Cost Challenge Taskforce Report. 2018; Available from: https://www.gov.uk/government/uploads/system/uploads/attachment data/file/721755/CCUS Cost Challenge Taskforce te rms of reference.pdf.

190. HM Government. Clean Growth: The UK Carbon Capture Usage and Storage deployment pathway 2018; Available from: www.gov.uk/beis

191. HM Government. What is the Industrial Clusters mission? . 2018; Available from: https://assets.publishing.service.gov.uk/government/uploads/system/uploads/attachment data/file/764468/clean-growthgrand-challenge-industrial-clusters-mission-infographic.PDF.

192. EIC. Energy Policy in 20202020 [cited 2019 18th May ]; Available from: https://www.eic.co.uk/energy-policy-in-2020/.

193. European Commission. A hydrogen strategy for a climate-neutral Europe. 2020 [cited 2020 25th October]; Available from: https://ec.europa.eu/energy/sites/ener/files/hydrogen strategy.pdf.

194. Hydrogen Strategy Now. The case for a UK-wide hydrogen strategy. 2020 [cited 2020 25th October]; Available from: https://hydrogenstrategynow.co.uk/\#: :text=A\%20UK\%2Dwide\%20hydrogen\%20economy,for\%20our\%20products\%20and\%20 skills.

195. Shayegh, S., D.L. Sanchez, and K. Caldeira, Evaluating relative benefits of different types of R\&D for clean energy technologies. Energy Policy, 2017. 107: p. 532-538.

196. BEIS. Hydrogen Supply Competition Phase 2 successful projects 2020 [cited 2020 4th March ]; Available from: https://www.gov.uk/government/publications/hydrogen-supply-competition/hydrogen-supply-programme-successfulprojects-phase-2.

197. UKRI. Industrial Decarbonisation. 2020 [cited 2020 24th Feb ]; Available from: https://www.ukri.org/innovation/industrialstrategy-challenge-fund/industrial-decarbonisation/.

198. UKRI. UKRI allocates funding for Industrial Decarbonisation Deployment and Roadmap projects. 202016 th April 2020 Available from: https://www.ukri.org/news/ukri-allocates-funding-for-industrial-decarbonisation-deployment-and-roadmap-projects/. 

network-innovation-competition.

200. NGN, Gas NIC Submission: H21 Phase 2 - Northern Gas Networks. 2019: OFGEM

201. OFGEM. Gas Network Innovation Competition. The 2020 Competition 2020 [cited 2020 18th May ]; Available from: https://www.ofgem.gov.uk/network-regulation-riio-model/current-network-price-controls-riio-1/network-innovation/gasnetwork-innovation-competition.

202. Hydrogen Taskforce. The Role of Hydrogen in Delivering Net Zero 2020; Hydrogen Taskforce:[p.2-18]. Available from: http://www.hydrogentaskforce.co.uk/wp-content/uploads/2020/03/Hydrogen-Taskforce-Report-Feb2020 web.pdf.

203. HM Treasury. Budget 2020: Delivering on our promises to the British people. 2020; p.62-95]. Available from: https://assets.publishing.service.gov.uk/government/uploads/system/uploads/attachment data/file/871799/Budget 2020 W eb Accessible Complete.pdf.

204. Balcombe, P., et al., How to decarbonise international shipping: Options for fuels, technologies and policies. Energy Conversion and Management, 2019. 182: p. 72-88.

205. OLEV. Tax benefits for ultra low emission vehicles 2018; p.2-3]. Available from: https://assets.publishing.service.gov.uk/government/uploads/system/uploads/attachment data/file/709655/ultra-lowemission-vehicles-tax-benefits.pdf.

206. OFGEM. Environmental Programmes 2020 [cited 2020 18th May ]; Available from: https://www.ofgem.gov.uk/environmentalprogrammes.

207. CCUS Advisory Group. Investment frameworks for development of CCUS in the UK 2019; Available from: http://www.ccsassociation.org/files/4615/6386/6542/CCUS_Advisory_Group_Final Report_22 July 2019.pdf.

208. Pique, S., et al. Comparative study of regulations, codes and standards and practices on hydrogen fuelling stations. International Journal of Hydrogen Energy, 2017. 42, 7429-7439 DOI: https://doi.org/10.1016/j.ijhydene.2016.02.158.

209. San Marchi, C., et al. Overview of the DOE hydrogen safety, codes and standards program, part 3: Advances in research and development to enhance the scientific basis for hydrogen regulations, codes and standards. International Journal of Hydrogen Energy, 2017. 42, 7263-7274 DOI: https://doi.org/10.1016/j.ijhydene.2016.07.014.

210. Hayter, D. HyLAW - Hydrogen Law and removal of legal barriers to the deployment of fuel cells and hydrogen applications. 2018; p.8-14]. Available from: https://www.hylaw.eu/sites/default/files/201901/HyLaw\%20UK\%20Policy\%20Paper Final December\%202018.pdf.

211. HyLaw. HyLaw Online Database 2018; Available from: https://www.hylaw.eu/database.

212. Isaac, T. Hydrogen: Deployment Barriers. 2019.

213. Frontier Economics. Business Models for Low Carbon Hydrogen Production. 2020 [cited 2020 25th October ]; Available from: https://assets.publishing.service.gov.uk/government/uploads/system/uploads/attachment data/file/910382/Business models for low carbon hydrogen production.pdf.

214. BEIS. Carbon Capture, Usage and Storage: A Government Response on potential business models for Carbon Capture, Usage and Storage. 2020 August 2020 [cited 2020 25th October]; Available from: https://assets.publishing.service.gov.uk/government/uploads/system/uploads/attachment data/file/909706/CCUSgovernment-response-business-models.pdf.

215. OFGEM. Offshore transmission. [cited 2020 19th June ]; Available from: https://www.ofgem.gov.uk/electricity/transmissionnetworks/offshore-transmission.

216. Dolci, F., et al. Incentives and legal barriers for power-to-hydrogen pathways: An international snapshot. International Journal of Hydrogen Energy, 2019. 44, 11394-11401 DOI: https://doi.org/10.1016/j.ijhydene.2019.03.045.

217. Haszeldine, S. Evidence to Business, Energy and Industrial Strategy Committee Inquiry: Carbon Capture, Usage and Storage: Supplementary. 2018; p.1-5]. Available from: https://www.parliament.uk/documents/commons-committees/business-energyand-industrial-strategy/Correspondence/Supplementary-evidence-Scottish-Carbon-Capture-Storage-17-19.pdf.

218. Parliament, U. Twenty-first Special Report. Appendix: Government Response 2019 [cited 2020 26th May ]; Available from: https://publications.parliament.uk/pa/cm201719/cmselect/cmbeis/2644/264402.htm.

219. Cadent. Future Billing Methodology. 2016; p.1-2]

220. Cadent. Innovating to transform experiences. Innovation Annual Summary 2019; p.9]. Available from: https://cadentgas.com/nggdwsdev/media/Downloads/Cadent-Innovation-Annual-Summary-18-19.pdf.

221. HSE. A guide to the Gas Safety (Management) Regulations 1996 2007; 2nd [p.49]. Available from: https://www.hse.gov.uk/pUbns/priced/l80.pdf.

222. Policy Connect. Next steps for the gas grid. 2017; p.15]. Available from: https://www.policyconnect.org.uk/cc/sites/site_cc/files/report/676/fieldreportdownload/nextstepsforthegasgridweb.pdf.

223. Floristean, A. HyLAW: Deliverable 4.2 List of Legal Barriers 2018; p.1-18]. Available from: https://www.hylaw.eu/sites/default/files/2019-01/D4.2\%20-\%20List\%20of\%20legal\%20barriers.pdf.

224. BEIS. Carbon capture usage and storage: third time lucky? . Twentieth Report of Session 2017-19 2019; p.16-17]. Available from: https://publications.parliament.uk/pa/cm201719/cmselect/cmbeis/1094/1094.pdf.

225. OfGEM. What is the RIIO-2 price control? . 2020 [cited 2020 4th March ]; Available from: https://www.ofgem.gov.uk/networkregulation-riio-model/network-price-controls-2021-riio-2/what-riio-2-price-control.

226. RIIO-2 Challenge Group. RIIO-2 Challenge Group Independent Report for Ofgem on RIIO-2 Business Plans 2020; Available from: https://www.ofgem.gov.uk/system/files/docs/2020/01/riio-2 challenge group independent report for ofgem on riio2 business plans.pdf.

227. Cadent. Network Innovation Competition Project Summary 19th June 2020; p.7]. Available from: https://www.ofgem.gov.uk/ofgem-publications/107831.

228. Energy, E. Installing accessible hydrogen refuelling stations. 2015; Available from: http://www.elementenergy.co.uk/wordpress/wp-content/uploads/2015/07/Installing-accessible-HRS-best-practice-guide_July-2015_FV.pdf.

229. Murugan, A., et al. Measurement challenges for hydrogen vehicles. International Journal of Hydrogen Energy, 2019. 44, 1932619333 DOI: https://doi.org/10.1016/j.ijhydene.2019.03.190.

230. Wang, D., et al. Development of regulations, codes and standards on composite tanks for on-board gaseous hydrogen storage. International Journal of Hydrogen Energy, 2019. 44, 22643-22653 DOI: https://doi.org/10.1016/j.ijhydene.2019.04.133. 
231. HyLaw. About HyLaw 2018 [cited 2020; Available from: https://www.hylaw.eu/about-hylaw.

232. Peterson, T.R., J.C. Stephens, and E.J. Wilson Public perception of and engagement with emerging low-carbon energy technologies: A literature review. MRS Energy \& Sustainability, 2015. 2, E11 DOI: 10.1557/mre.2015.12.

233. Kern, F., et al. The political economy of carbon capture and storage: An analysis of two demonstration projects. Technological Forecasting and Social Change, 2016. 102, 250-260 DOI: https://doi.org/10.1016/j.techfore.2015.09.010.

234. Ricci, M., P. Bellaby, and R. Flynn What do we know about public perceptions and acceptance of hydrogen? A critical review and new case study evidence. International Journal of Hydrogen Energy, 2008. 33, 5868-5880 DOI:

https://doi.org/10.1016/j.ijhydene.2008.07.106.

235. Decarbonised Gas Alliance and Public Frist. Getting net zero done: The crucial role of decarbonised gas and how to support it 2020; p.6]. Available from: https://www.dgalliance.org/wp-content/uploads/2020/05/DGA-Getting-Net-Zero-Done-final-May2020.pdf.

236. Bögel, P., et al. The role of attitudes in technology acceptance management: Reflections on the case of hydrogen fuel cells in Europe. Journal of Cleaner Production, 2018. 188, 125-135 DOI: https://doi.org/10.1016/j.jclepro.2018.03.266.

237. Tarigan, A.K.M. and S.B. Bayer Temporal change analysis of public attitude, knowledge and acceptance of hydrogen vehicles in Greater Stavanger, 2006-2009. Renewable and Sustainable Energy Reviews, 2012. 16, 5535-5544 DOI:

https://doi.org/10.1016/j.rser.2012.05.045.

238. Iribarren, D., et al. Assessing the social acceptance of hydrogen for transportation in Spain: An unintentional focus on target population for a potential hydrogen economy. International Journal of Hydrogen Energy, 2016. 41, 5203-5208 DOI: https://doi.org/10.1016/j.ijhydene.2016.01.139.

239. Schmoyer, R., et al. Results of the 2008/2009 Knowledge and Opintions Surveys Conducted for the U.S. Department of Energy Hydrogen Program. 2010.

240. Itaoka, K., A. Saito, and K. Sasaki Public perception on hydrogen infrastructure in Japan: Influence of rollout of commercial fuel cell vehicles. International Journal of Hydrogen Energy, 2017. 42, 7290-7296 DOI:

https://doi.org/10.1016/j.ijhydene.2016.10.123.

241. Heinz, B. and G. Erdmann Dynamic effects on the acceptance of hydrogen technologies-an international comparison. International Journal of Hydrogen Energy, 2008. 33, 3004-3008 DOI: https://doi.org/10.1016/j.ijhydene.2008.02.068.

242. Scott, M. and G. Powells Sensing hydrogen transitions in homes through social practices: Cooking, heating, and the decomposition of demand. International Journal of Hydrogen Energy, 2020. 45, 3870-3882 DOI: https://doi.org/10.1016/j.ijhydene.2019.12.025.

243. Ono, K., E. Kato, and K. Tsunemi Does risk information change the acceptance of hydrogen refueling stations in the general Japanese population? International Journal of Hydrogen Energy, 2019. 44, 16038-16047 DOI:

https://doi.org/10.1016/j.ijhydene.2019.04.257.

244. Fylan, F., M. Fletcher, and S. Christmas. H21: Public perceptions of converting the gas network to hydrogen. 2020; p.35]. Available from: https://www.h21.green/wp-content/uploads/2018/01/SBT2251-Leeds-Beckett-Leeds-Sustainability-InstituteH21-Report-Singles.pdf.

245. Schmidt, A. and W. Donsbach Acceptance factors of hydrogen and their use by relevant stakeholders and the media. International Journal of Hydrogen Energy, 2016. 41, 4509-4520 DOI: https://doi.org/10.1016/j.ijhydene.2016.01.058.

246. Williams, H., et al. Public acceptability of the use of hydrogen for heating and cooking in the home. 2018; p.5]. Available from: https://www.theccc.org.uk/publication/public-acceptability-of-hydrogen-in-the-home-madano-and-element-energy/.

247. Dutschke, E., P. Upham, and U. Schneider. Hydrogen acceptance in the transition phase Report on results of the stakeholder survey 2017; p.89-91]. Available from: http://hyacinthproject.eu/.

248. Emmerich, P., et al. Public acceptance of emerging energy technologies in context of the German energy transition. Energy Policy, 2020. 142, 111516 DOI: https://doi.org/10.1016/j.enpol.2020.111516.

249. Scott, M. and G. Powells Towards a new social science research agenda for hydrogen transitions: Social practices, energy justice, and place attachment. Energy Research \& Social Science, 2020. 61, 101346 DOI: https://doi.org/10.1016/j.erss.2019.101346.

250. Nataly Echevarria Huaman, R. and T. Xiu Jun Energy related CO2 emissions and the progress on CCS projects: A review. Renewable and Sustainable Energy Reviews, 2014. 31, 368-385 DOI: https://doi.org/10.1016/j.rser.2013.12.002.

251. Global CCS Institute. Targeting Climate Change 2019; p.19-22]. Available from: https://www.globalccsinstitute.com/statusccs19.

252. Global CCS Institute. Consultation Submission. Global Carbon Capture and Storage Institute Response to the National Hydrogen Strategy Issues Papers 2019; p.1-2]. Available from: https://www.globalccsinstitute.com/wp-content/uploads/2019/08/GlobalCCS-Institute Response-to-the-National-Hydrogen-Strategy-Issues-Papers July-2019-002.pdf.

253. WSP. The CarbonNet Project. Development of a CO2 Specification for a CCS Hub Network 2016; p.3]. Available from: https://www.globalccsinstitute.com/archive/hub/publications/199363/carbonnet-project-development-co2-specification-ccshub-network.pdf.

254. Hydrocarbons Technology. Alberta Carbon Trunk Line, Alberta 2018; Available from: https://www.hydrocarbonstechnology.com/projects/alberta-carbon-trunk-line-alberta/.

255. Port of Rotterdam. CCS project Porthos a step closer 2019 [cited 2020 10th May]; Available from: https://www.portofrotterdam.com/en/news-and-press-releases/ccs-project-porthos-a-step-closer.

256. CarbonNet. The CarbonNet Project. 2020 [cited 2020 10th May]; Available from: https://earthresources.vic.gov.au/projects/carbonnet-project.

257. Air Liquide. Technology status of hydrogen production from fossil fuels w/CCS. 2019; p.9]. Available from: http://ieahydrogen.org/pdfs/3-3-Del-Corso 2019-AIR-LIQUIDE-H2-production.aspx.

258. ExxonMobil. Rotterdam refinery 2019 [cited 2020 10th May]; Available from: https://www.exxonmobil.be/enbe/company/locations/netherlands/rotterdam-refinery.

259. H-Vision. Blue hydrogen as accelerator and pioneer for energy transition in the industry. 2019; p.46-47]. Available from: https://www.deltalings.nl/h-vision-en.

260. ZEROCO2. Great Plains Synfuels Plant 2017 [cited 2020 7th May ]; Available from: http://www.zeroco2.no/projects/the-greatplains-synfuels-plant. 
261. Brownsort, P. Methodologies for cluster development and best practices for data collection in the promising regions. Part 1: Industrial CCUS Clusters and CO2 transport systems: methodologies for characterisation and definition 2019; Available from: https://www.strategyccus.eu/sites/default/files/STRATEGY CCUS T2-1 ICCS Methodology V1.2.pdf.

262. Port of Rotterdam. Ongoing Projects Energy Transition 2020 [cited 2020 7th May]; Available from: https://www.portofrotterdam.com/en/doing-business/port-of-the-future/energy-transition/ongoing-projects.

263. Port of Rotterdam. Port of Rotterdam becomes international hyrogen hub. 2020; p.1]. Available from: https://www.portofrotterdam.com/sites/default/files/hydrogen-vision-port-of-rotterdam-authority-may2020.pdf?token=XHpe4PNr.

264. OGCl. OGCI Climate Investments announces progression of the UK's first commercial full-chain Carbon Capture, Utilization and Storage Project. 2018 [cited 2020 5th May ]; Available from: https://oilandgasclimateinitiative.com/climate-investmentsannounces-progression-of-the-uks-first-commercial-full-chain-carbon-capture-utilization-and-storage-project/.

265. OGCl. Clean Gas Project 2018 [cited 2020 5th May]; Available from: https://oilandgasclimateinitiative.com/clean-gas-project/. 266. Duckett, A., Teesside industry evolves its CCS pitch and pushes plans to host net zero cluster, in Industry 2020, The Chemical Engineer.

267. Teesside, N.Z. Project. 2020 [cited 2020 5th May ]; Available from: https://netzerotees.wpengine.com/project/.

268. National Infrastructure Planning. The 'Net Zero Teesside Project'. 2020 [cited 2020 5th May ]; Available from: https://infrastructure.planninginspectorate.gov.uk/projects/north-east/the-net-zero-teesside-project/?ipcsection=overview. Zero Carbon Humber. Zero Carbon Humber project details. 2020 [cited 2020 5th May ]; Available from: https://www.zerocarbonhumber.co.uk/the-vision/.

270. Drax. Leading energy companies announce new zero-carbon UK partnership. 2019 [cited 2020 5th May]; Available from: https://www.drax.com/press release/energy-companies-announce-new-zero-carbon-uk-partnership-ccus-hydrogen-beccshumber-equinor-national-grid/.

271. Element Energy. Zero carbon humber. The impacts of decarbonising Yorkshire and the Humber 2019; p.3]. Available from: www.element-energy.co.uk/wordpress/wp-content/uploads/2019/11/20191104 Element-Energy Zero-Carbon-HumberStudy Summary-for-Publication.pdf.

272. Cadent. HyNet North West: From Vision to Reality 2018; Available from: www.hynet.co.uk.

273. Progressive Energy. HyNet Low Carbon Hydrogen Plant Phase 1 Report for BEIS 2019; Available from: https://assets.publishing.service.gov.uk/government/uploads/system/uploads/attachment data/file/866401/HS384 Progressive Energy - HyNet hydrogen.pdf.

274. Pale Blue Dot. Acorn CCS \& Acorn Hydrogen. Project Overview 2020; Available from: https://pale-blu.com/acorn/.

275. Pale Blue Dot. Acorn Hydrogen: Project Summary. 2019; p.5]. Available from: https://assets.publishing.service.gov.uk/government/uploads/system/uploads/attachment data/file/866380/Phase 1 Pale BI.

276. Element Energy. Study 1: Hydrogen for economic growth Hy-Impact Series 2019; p.24]. Available from: http://www.elementenergy.co.uk/wordpress/wp-content/uploads/2019/11/Element-Energy-Hy-Impact-Series-Study-1-Hydrogen-for-EconomicGrowth.pdf.

277. Element Energy. Towards Net Zero: The implications of the transition to net zero emissions for the Engineering Construction Industry p.23]. Available from: http://www.element-energy.co.uk/wordpress/wpcontent/uploads/2020/03/20200304 EE ECITB Towards-Net-Zero-Report Implications-for-the-ECI.pdf.

278. ZERO2050. What is ZERO2050? 2020 [cited 2020 5th May ]; Available from: https://www.zero2050.co.uk/about-zero2050/.

279. FLEXIS. About Us. 2020 [cited 2020 5th May ]; Available from: https://www. flexis.wales/about/.

280. HM Government. ISCF decarbonisation of industrial clusters: deployment. 2019 [cited 2020 7th May]; Available from: https://apply-for-innovation-funding.service.gov.uk/competition/498/overview? ga=2.104762500.520851221.15889662841955200589.1564827663\#scope.

281. Hydrogen Europe. French and German TSOs sign Hydrogen MoU. 2020 [cited 2020 5th June ]; Available from: https://www.hydrogeneurope.eu/news/french-and-german-tsos-sign-hydrogen-mou.

282. Gaz, G. Hydrogen: Signing of a European Memorandum of Understanding 2020 [cited 2020 5th June ]; Available from: http://www.grtgaz.com/en/press/press-releases/news-details/article/hydrogene.html.

283. IRENA. Hydrogen: A renewable energy perspective 2019; p.35]. Available from: https://www.irena.org//media/Files/IRENA/Agency/Publication/2019/Sep/IRENA Hydrogen 2019.pdf.

284. FuelCellsWorks. World's first international transport of hydrogen from Brunei to Japan. 2020 [cited 2020 5th June ]; Available from: https://fuelcellsworks.com/news/worlds-first-international-transport-of-hydrogen-from-brunei-to-japan/.

285. Sayashi, T. The World's First Global Hydrogen Supply Chain Demonstration Project. 2017; Available from: https://www.mitsui.com/jp/en/release/2017/1224164 10832.html.

286. HESC. Hydrogen Energy Supply Chain 2020 [cited 2020 5th June]; Available from: https://hydrogenenergysupplychain.com/supply-chain/.

287. Nagashima, M. Japan's hydrogen strategy and its economic and geopolitical implications 2018; p.32]. Available from: https://www.ifri.org/sites/default/files/atoms/files/nagashima_japan hydrogen 2018 .pdf.

288. Energy, D.o. Hydrogen \& Fuel Cells Program International Hydrogen and Fuel Cell Activities [cited 2020 5th June]; Available from: https://www.hydrogen.energy.gov/international.html.

289. Mission Innovation. IC8: Renewable and Clean Hydrogen 2020 [cited 2020 24th Feb ]; Available from: http://missioninnovation.net/our-work/innovation-challenges/renewable-and-clean-hydrogen/.

290. IEA. Technology collaboration: Advancing the research, development and commercialisation of energy technologies. About the TCP 2020 [cited 2020 5th June ]; Available from: https://www.iea.org/areas-of-work/technology-collaboration.

291. IPHE. Our Mission. 2020 [cited 2020 5th June ]; Available from: https://www.iphe.net/.

292. Hydrogen Europe. About Us 2017 [cited 2020 5th June ]; Available from: https://hydrogeneurope.eu/about-us-2.

293. EERE. Hydrogen and Fuel Cell Technologies Office. 2020 [cited 2020 5th June ]; Available from: https://www.energy.gov/eere/fuelcells/hydrogen-and-fuel-cell-technologies-office.

294. FCH JU. Vision \& Objectives 2020 [cited 2020 5th June]; Available from: https://www.fch.europa.eu/page/vision-objectives.

295. Hydrogen Council. The Hydrogen Council - An Introduction 2020 [cited 2020 5th June ]; Available from:

https://hydrogencouncil.com/en/. 
World Energy Council. Hydrogen Global 2020 [cited 2020 5th June ]; Available from: https://www.worldenergy.org/impactcommunities/innovation/hydrogen-charter.

297. IEAGHG, Techno - Economic Evaluation of SMR Based Standalone (Merchant) Hydrogen Plant with CCS 2017: Cheltenham, United Kingdom.

298. Navas-Anguita, Z., et al., Prospective techno-economic and environmental assessment of a national hydrogen production mix for road transport. Applied Energy, 2020. 259: p. 114121.

299. El-Emam, R.S. and I. Khamis, Advances in nuclear hydrogen production: Results from an IAEA international collaborative research project. International Journal of Hydrogen Energy, 2019. 44(35): p. 19080-19088.

300. James, B.D., D.A. DeSantis, and G. Saur, Final Report: Hydrogen Production Pathways Cost Analysis (2013 - 2016). 2016. p. 11.

301. Proost, J., State-of-the art CAPEX data for water electrolysers, and their impact on renewable hydrogen price settings. International Journal of Hydrogen Energy, 2019. 44(9): p. 4406-4413. 
Appendix A: Data Used to Plot UK CO2 Emissions per Sector (Figure 1 in Manuscript)

\begin{tabular}{ccccc}
\hline Sector & $\begin{array}{c}\text { Emissions in } \\
\mathbf{1 9 9 0}\left(\mathbf{M t C O}_{\mathbf{2 e}}\right)\end{array}$ & $\begin{array}{c}\text { Contribution } \\
\text { Percentage }\end{array}$ & $\begin{array}{c}\text { Emissions in } \\
\mathbf{2 0 1 9}\left(\mathbf{M t C O}_{\mathbf{2 e}}\right)\end{array}$ & $\begin{array}{c}\text { Contribution } \\
\text { Percentage }\end{array}$ \\
\hline $\begin{array}{c}\text { Energy Supply } \\
\text { (Including Power }\end{array}$ & 242.1 & $40.64 \%$ & 90.1 & $25.62 \%$ \\
$\begin{array}{c}\text { Generation) } \\
\text { Business and Industrial }\end{array}$ & 111.9 & $18.78 \%$ & 74.4 & $21.16 \%$ \\
Process & 125.3 & $21.03 \%$ & 119.6 & $34.02 \%$ \\
Transport & 13.4 & $2.25 \%$ & 8.0 & $2.28 \%$ \\
Public & 78.4 & $13.16 \%$ & 65.2 & $18.55 \%$ \\
Residential & 6.5 & $1.09 \%$ & 5.7 & $1.63 \%$ \\
Agriculture & 1.4 & $0.24 \%$ & 0.2 & $0.07 \%$ \\
Waste Management & 595.7 & $100 \%$ & 351.5 & $100 \%$ \\
Total & & & & \\
\hline
\end{tabular}

This is provisional 2019 emission data retrieved from the Department of Business Energy and Industrial Strategy

[Data Source] BEIS, 2019 UK Greenhouse Gas Emissions, Provisional Figures in Statistical Release: National Statistics 2020. Available from:

https://assets.publishing.service.gov.uk/government/uploads/system/uploads/attachment data/file/87 5485/2019_UK_greenhouse_gas_emissions_provisional_figures_statistical_release.pdf

Table A. 1 - Data Used to Plot UK $\mathrm{CO}_{2}$ Emissions per Sector in Figure 1 (Section 2) in Manuscript. 


\begin{tabular}{|c|c|c|c|c|c|c|c|c|}
\hline Source & $\begin{array}{c}\text { Year of } \\
\text { Publication }\end{array}$ & $\begin{array}{c}\text { Hydrogen Production } \\
\text { Technology }\end{array}$ & $\begin{array}{l}\text { Production } \\
\text { Rate (as in } \\
\text { source) }\end{array}$ & $\begin{array}{l}\text { Production Rate } \\
\text { (kg/day) }\end{array}$ & $\begin{array}{l}\text { CAPEX (as is in } \\
\text { source) }\end{array}$ & $\begin{array}{c}\text { CAPEX ( } \mathbf{f}_{2019 /} \\
k w)\end{array}$ & $\begin{array}{l}\text { Hydrogen } \\
\text { Production Cost } \\
\text { (as in source) }\end{array}$ & $\begin{array}{c}\text { Hydrogen } \\
\text { Production } \\
\text { Cost } \\
\left(\left.\right|_{2019} / \mathrm{kg}\right) \text { - } \\
\text { Year given }\end{array}$ \\
\hline [88] & 2017 & $\mathrm{SMR}^{7}$ & $\begin{array}{l}379387 \\
\mathrm{~kg} / \text { day }\end{array}$ & 397387 & NA & NA & $\$ 2.08 / \mathrm{kg}$ & 1.73 \\
\hline [297] & 2017 & $\mathrm{SMR}^{1}$ & $\begin{array}{l}100000 \\
\mathrm{Nm}^{3} / \mathrm{h}\end{array}$ & 215760 & $€ 170.95 \mathrm{~m}$ & 536 & $11.4 \mathrm{c} / \mathrm{Nm}^{3}$ & 1.19 \\
\hline [93] & 2017 & $\mathrm{SMR}^{8}$ & NA & NA & $£ 315 / K w$ & \multirow{2}{*}{$\begin{array}{l}337 \\
258\end{array}$} & $3.5 p / k W h$ & 1.25 \\
\hline [298] & 2020 & $\mathrm{SMR}^{1}$ & NA & NA & $€_{2017} 8.7 / \mathrm{GJ} / \mathrm{y}$ & & NA & NA \\
\hline [101] & 2019 & $\mathrm{SMR}^{9}$ & $107.4 \mathrm{kNm}^{3}$ & 231726 & $f 261 \mathrm{~m}$ & 811 & NA & NA \\
\hline [297] & 2017 & $\begin{array}{l}\text { SMR (with CCS) } \\
\text { Upper Limit }{ }^{10} \\
\text { SMR (with CCS) } \\
\text { Lower Limit }^{11}\end{array}$ & $\begin{array}{l}100000 \\
\mathrm{Nm}^{3} / \mathrm{h} \\
100000 \\
\mathrm{Nm}^{3} / \mathrm{h}\end{array}$ & 215760 & $€ 305.3 \mathrm{~m}$ & 958 & $16.5 \mathrm{c} / \mathrm{Nm}^{3}$ & 1.72 \\
\hline [88] & 2017 & SMR (with CCS) ${ }^{12}$ & $\begin{array}{l}379387 \\
\mathrm{~kg} / \mathrm{day}\end{array}$ & 379387 & NA & NA & $\$ 2.27 / \mathrm{kg}$ & 1.89 \\
\hline$[93]$ & 2017 & SMR (with CCS) ${ }^{13}$ & NA & NA & $£ 409.5 / \mathrm{Kw}$ & 438 & $3.5 p / k W h$ & 1.25 \\
\hline [298] & 2020 & SMR (with CCS) ${ }^{14}$ & NA & NA & $€_{2017} 14.5 / \mathrm{GJ} / \mathrm{y}$ & 430 & NA & NA \\
\hline [88] & 2017 & ATR $^{15}$ & NA & NA & $\$ 499.23 / \mathrm{kW}$ & 415 & $\$ 1.48 / \mathrm{kg}$ & 1.23 \\
\hline [101] & 2019 & ATR $^{2}$ & $107.4 \mathrm{kNm}^{3}$ & 231726 & f195m & 606 & NA & NA \\
\hline [273] & 2019 & $\mathrm{LCH}^{16}$ & $100 \mathrm{kNm}^{3}$ & 215760 & f253.9m & 847 & NA & NA \\
\hline [101] & 2019 & LCH (with CCS) ${ }^{7}$ & $107.4 \mathrm{kNm}^{3}$ & 231726 & f159m & 494 & NA & NA \\
\hline$[88]$ & 2017 & $\begin{array}{l}\text { Gasification (without CCS) } \\
\text { Gasification (without } C(S)^{2}\end{array}$ & $\begin{array}{l}139.7 \mathrm{tn} / \text { day } \\
2 \mathrm{tn} / \mathrm{day}\end{array}$ & $\begin{array}{c}139700 \\
2000\end{array}$ & $\begin{array}{l}\$ 149.3 \mathrm{~m} \\
\$ 6.4 \mathrm{~m}\end{array}$ & $\begin{array}{c}640 \\
1916\end{array}$ & $\begin{array}{l}\$ 1.77 / \mathrm{kg} \\
\$ 2.05 / \mathrm{kg}\end{array}$ & $\begin{array}{l}1.47 \\
1.71\end{array}$ \\
\hline [298] & 2020 & Gasification (without CCS) ${ }^{2}$ & NA & NA & $€_{2017} 48.27 / \mathrm{GJ} / \mathrm{y}$ & 1431 & NA & NA \\
\hline
\end{tabular}

${ }^{7}$ Based on conventional SMR process. Where, syngas from WGS is fed to PSA. $\mathrm{CO}_{2}$ in PSA tail gas is fed back to SMR and leaves as flue gas to the atmosphere. ${ }^{8}$ No detailed process description could be identified.

${ }_{9}^{9}$ Majority of $\mathrm{CO}_{2}$ located in flue gas stream.

${ }^{10}$ Carbon is captured from flue gas using MEA. Processes included within CCS cost assessment include cooling, absorbing, stripping, compression, dehydration, transportation and storage.

${ }^{11}$ Carbon is captured from shifted syngas using MDEA. Processes included within CCS cost assessment include absorbing, stripping, compression, dehydration, transportation and storage.

${ }^{12}$ Carbon is captured from shifted syngas using an amine solvent. Processes included within CCS cost assessment include absorbing, stripping, compression, transportation, injection and storage.

${ }^{13}$ No detailed process description could be identified so carbon capture technology is unknown. $\mathrm{CO}_{2}$ transportation and storage costs are included in cost assessment.

${ }^{14}$ Carbon is captured from shifted syngas using chemical absorption. $\mathrm{CO}_{2}$ compression, transportation and storage costs are included in cost assessment.

${ }^{15} 90 \%$ carbon capture is observed using ceramic ion transfer membranes. $\mathrm{CO}_{2}$ transportation and storage costs are not included in this cost assessment.

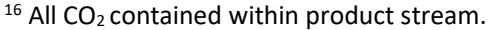




\begin{tabular}{|c|c|c|c|c|c|c|c|c|}
\hline [125] & 2015 & Gasification (without CCS) ${ }^{2}$ & NA & NA & f3708/kW & 4046 & NA & NA \\
\hline [93] & 2017 & Gasification (without CCS) ${ }^{2}$ & NA & NA & $£ 1700 / \mathrm{kW}$ & 1820 & $3.4 \mathrm{p} / \mathrm{kWh}$ & 1.21 \\
\hline [125] & 2015 & Gasification (with CCS) ${ }^{7}$ & NA & NA & $£ 4902 / \mathrm{kW}$ & 5348 & NA & NA \\
\hline [93] & 2017 & Gasification (with CCS) ${ }^{7}$ & NA & NA & $f 2100 / \mathrm{kW}$ & 2248 & 3.6p/kWh & 1.28 \\
\hline [88] & 2017 & Nuclear Thermolysis (Cu-Cl Cycle) & $7 \mathrm{tn} /$ day & 7000 & $\$ 39.6 \mathrm{~m}$ & 3388 & $\$ 2.17 / \mathrm{kg}$ & 1.80 \\
\hline [299] & 2019 & Nuclear Thermolysis (Cu-Cl Cycle) & $4.25 \mathrm{~kg} / \mathrm{s}$ & 390528 & $\$ 400.23 \mathrm{~m} /$ unit & 579 & $\$ 2.63 / \mathrm{kg}$ & 2.24 \\
\hline [88] & 2017 & Nuclear Thermolysis (S-I Cycle) & 583tn/day & 583000 & $\$ 2107.6 \mathrm{~m}$ & 2165 & $\$ 2.86 / \mathrm{kg}$ & 2.19 \\
\hline [299] & 2019 & Nuclear Thermolysis (S-I Cycle) & $0.68 \mathrm{~kg} / \mathrm{s}$ & 58752 & $\$ 100.00 \mathrm{~m} /$ unit & 961 & $\$ 2.83 / \mathrm{kg}$ & 2.22 \\
\hline [299] & 2019 & Nuclear Thermolysis (S-I Cycle) & $0.77 \mathrm{~kg} / \mathrm{s}$ & 66528 & $\$ 143.00 \mathrm{~m} /$ unit & 1213 & $\$ 2.37 / \mathrm{kg}$ & 1.86 \\
\hline [93] & 2017 & Electrolysis & NA & NA & $\begin{array}{l}\text { f900/kW (electrical } \\
\text { input) }\end{array}$ & 963 & $7 \mathrm{p} / \mathrm{kWh}$ & 2.50 \\
\hline [107] & 2018 & PEM Electrolysis & NA & NA & $\begin{array}{l}\text { f600/kW(electrical } \\
\text { input) }\end{array}$ & 604 & NA & NA \\
\hline [107] & 2018 & Alkaline Electrolysis & NA & NA & $\begin{array}{l}\text { f750/kW (electrical } \\
\text { input) }\end{array}$ & 755 & NA & NA \\
\hline [301] & 2019 & Alkaline Electrolysis & NA & NA & $\begin{array}{c}€ 750 / \mathrm{kW} \\
\text { (electrical input) }\end{array}$ & 659 & NA & NA \\
\hline [300] & 2016 & SOEC Electrolysis & NA & NA & NA & NA & $\$ 4.96 / \mathrm{kg}$ & 4.12 \\
\hline [107] & 2018 & SOEC Electrolysis & NA & NA & $\begin{array}{c}\text { f1640/kW } \\
\text { (electrical input) }\end{array}$ & 1652 & NA & NA \\
\hline
\end{tabular}

Where applicable, the available data retrieved from the sources highlighted was converted into consistent units for hydrogen production rate, CAPEX and hydrogen production costs using the data shown in Table B.1.

For CAPEX and Hydrogen Production Costs, all values shown are representative of $f_{2019}$ value. This was calculated using the Chemical Engineering Cost Index. Please see the equation used below (Equation B.1).

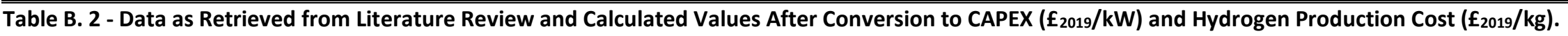

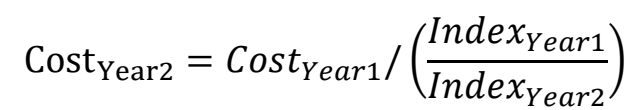

Equation B. 1 - Equation Used to Convert CAPEX and Hydrogen Production Costs to $f_{2019}$ Equivalent. 


\begin{tabular}{|c|c|c|c|c|c|c|c|c|c|}
\hline & SMR & SMR With CCS & ATR & LCH & LCH With CCS & $\begin{array}{l}\text { Biomass } \\
\text { Gasification }\end{array}$ & $\begin{array}{c}\text { Biomass } \\
\text { Gasification } \\
\text { With CCS }\end{array}$ & $\begin{array}{l}\text { Nuclear } \\
\text { Thermolysis }\end{array}$ & Electrolysis \\
\hline \multicolumn{10}{|c|}{ CAPEX $\left(\mathbf{f}_{2019} / \mathbf{k W}\right)$} \\
\hline Upper & 536 & 958 & 606 & 494 & 847 & 4046 & 5348 & 3388 & 604 \\
\hline Median & 486 & 615 & 511 & 494 & 847 & 1971 & 3798 & 1661 & 927 \\
\hline \multirow[t]{2}{*}{ Lower } & 258 & 430 & 415 & 494 & 847 & 640 & 2248 & 579 & 1652 \\
\hline & \multicolumn{9}{|c|}{ Hydrogen Production Cost (f/kg) } \\
\hline Upper & 1.73 & 1.89 & 1.23 & - & - & 1.71 & 1.28 & 2.24 & 4.25 \\
\hline Median & 1.39 & 1.57 & 1.23 & - & - & 1.46 & 1.28 & 2.06 & 3.63 \\
\hline Lower & 1.19 & 1.25 & 1.23 & - & - & 1.21 & 1.28 & 1.80 & 2.50 \\
\hline & \multicolumn{9}{|c|}{$\begin{array}{l}\text { The data in this table was calculated using column } 6 \text { (CAPEX }\left(f_{2019 / k w)}\right) \text { and column } 8 \text { (Hydrogen Production Cost (f/kg) of Appendix Table B. } \\
\text { This was used to plot the CAPEX and Hydrogen Production Cost graphs illustrated in Figure } 4 .\end{array}$} \\
\hline
\end{tabular}

Table B. 3 - Data Used to Plot Economic Graphs Shown in Figure 3 (Section 5.3) in Manuscript.

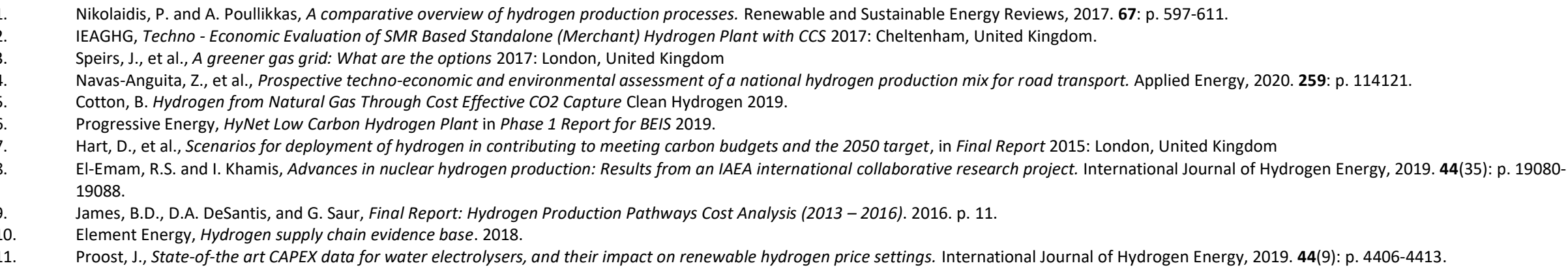


